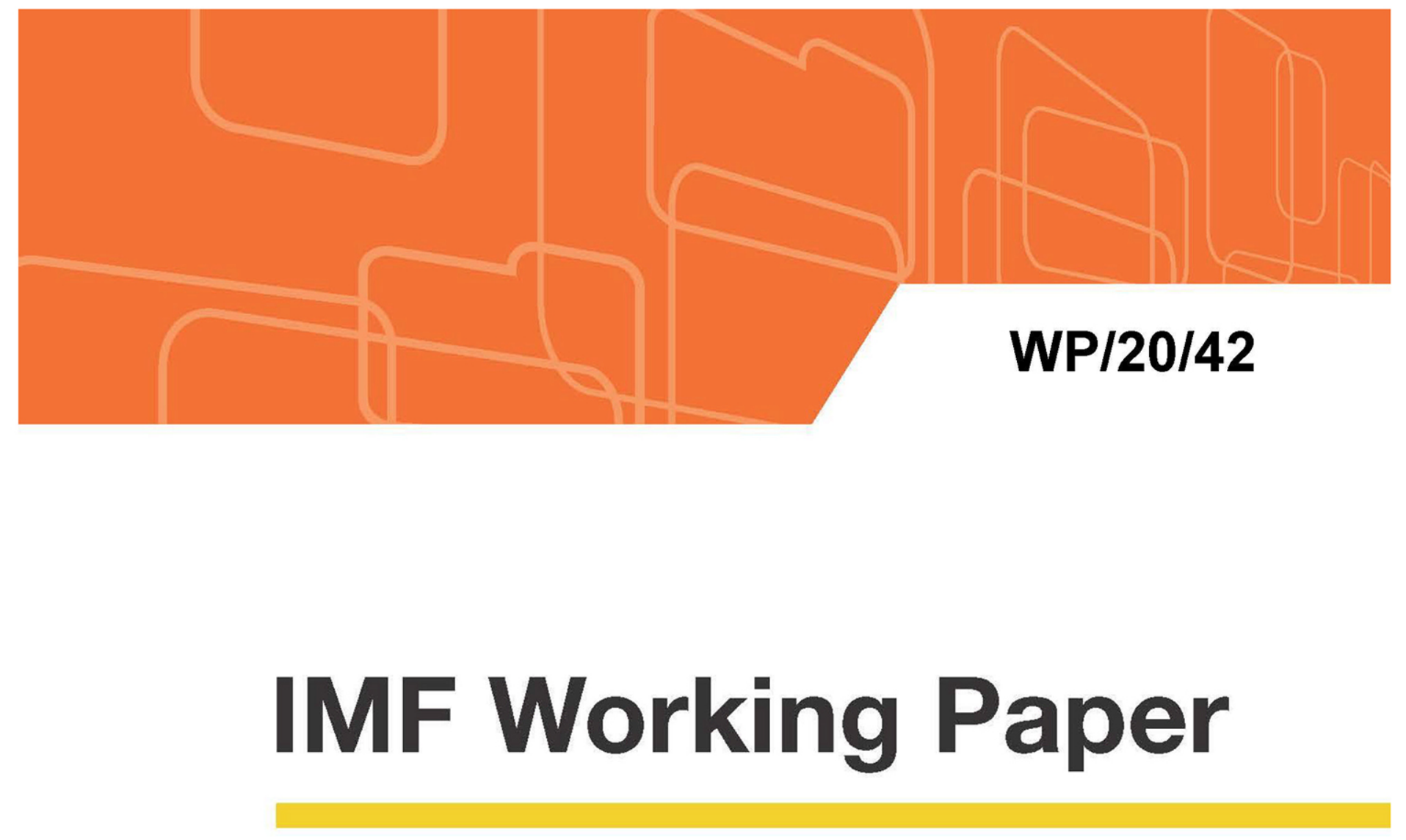

\title{
Household Debt and House Prices-at-risk: A Tale of Two Countries
}

By Adrian Alter and Elizabeth M. Mahoney

IMF Working Papers describe research in progress by the author(s) and are published to elicit comments and to encourage debate. The views expressed in IMF Working Papers are those of the author(s) and do not necessarily represent the views of the IMF, its Executive Board, or IMF management. 


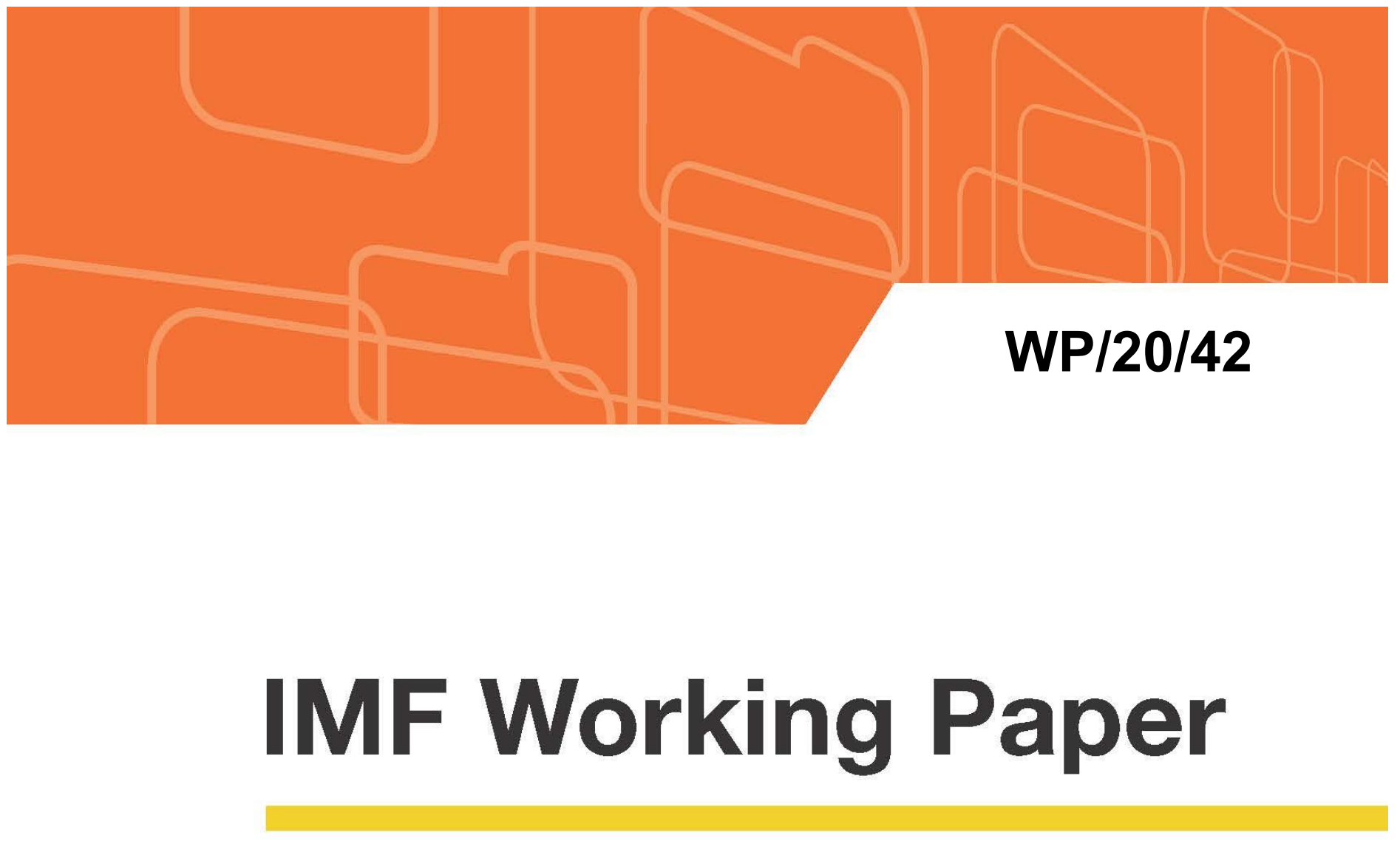

\section{Household Debt and House Prices-at-risk: A Tale of Two Countries}

IMF Working Papers describe research in progress by the author(s) and are published to elicit comments and to encourage debate.

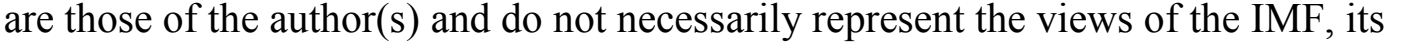

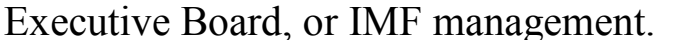

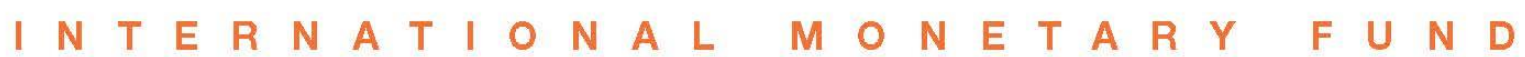




\title{
IMF Working Paper
}

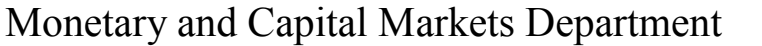

\author{
Household Debt and House Prices-at-risk: A Tale of Two Countries \\ Prepared by Adrian Alter and Elizabeth M. Mahoney ${ }^{1}$
}

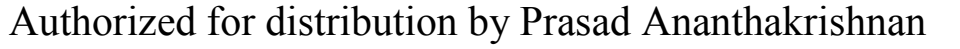

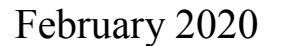

\begin{abstract}

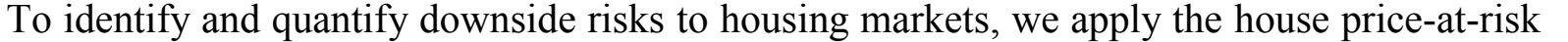

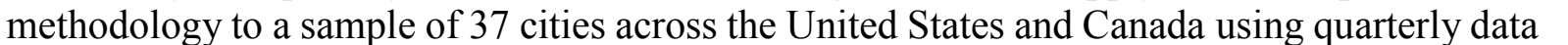

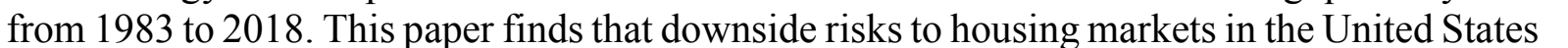

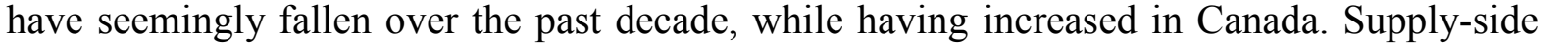

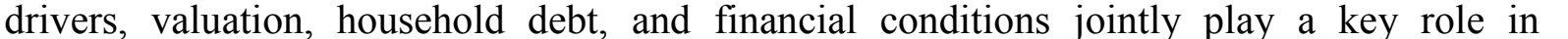

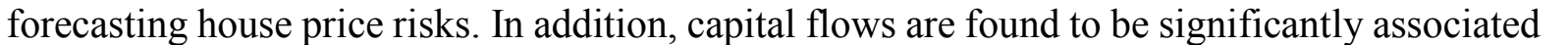

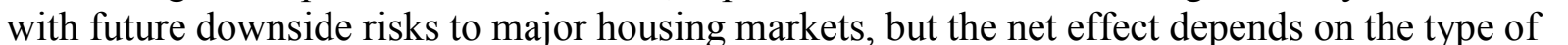

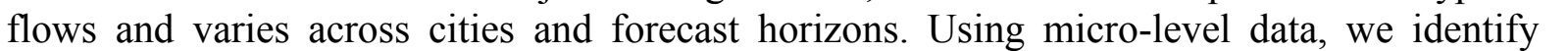

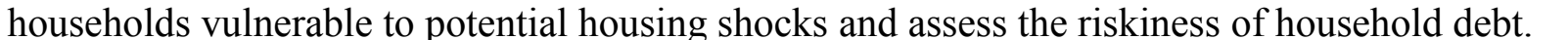

IMF Working Papers describe research in progress by the author(s) and are published to elicit comments and to encourage debate. The views expressed in IMF Working Papers are those of the author(s) and do not necessarily represent the views of the IMF, its Executive Board, or IMF management.

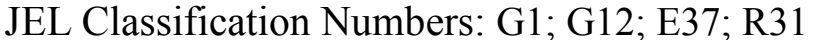

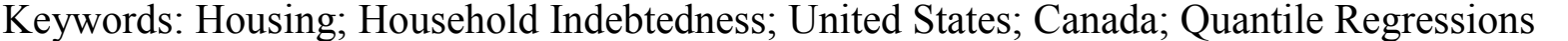

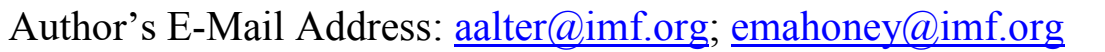

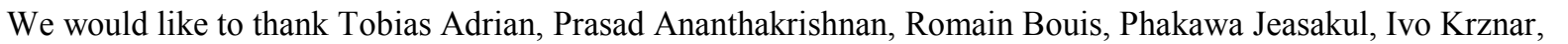

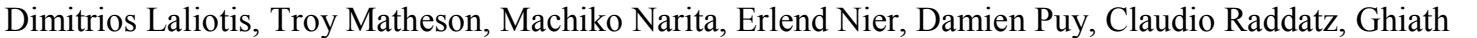

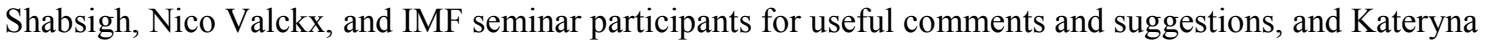

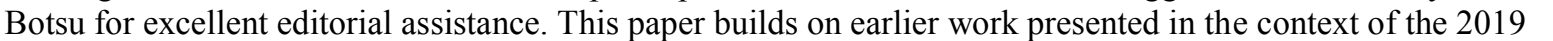

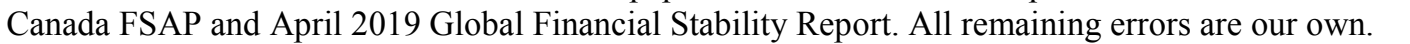




\section{Contents}

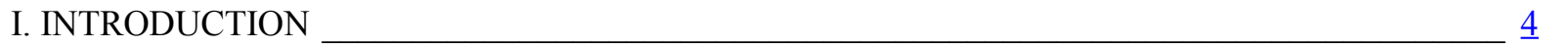

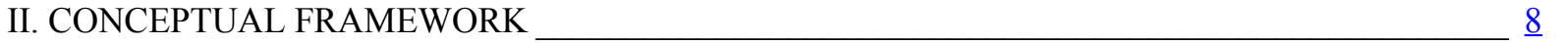

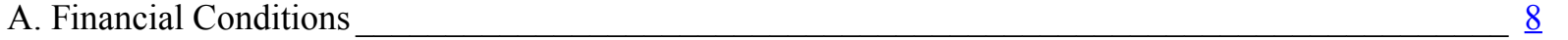
매

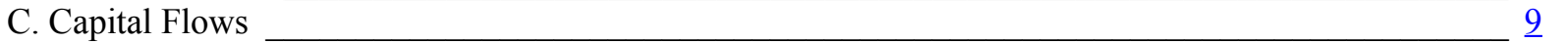

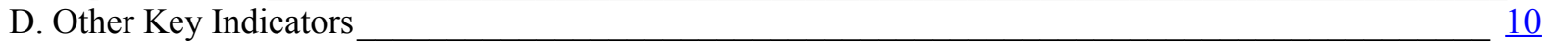

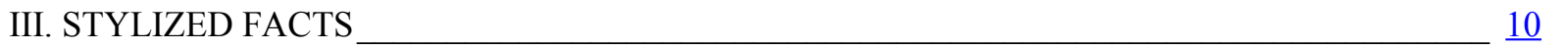

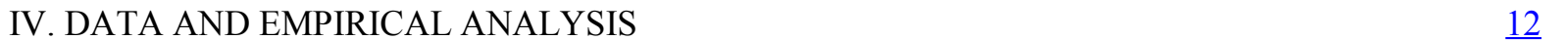

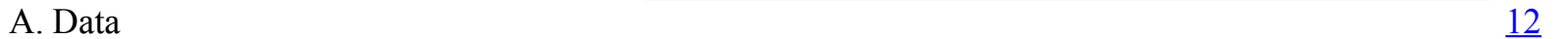

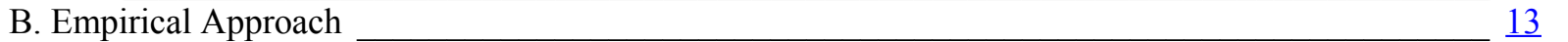

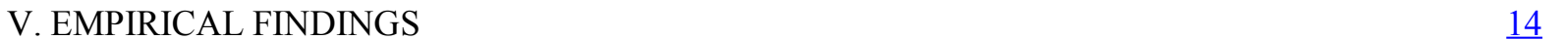

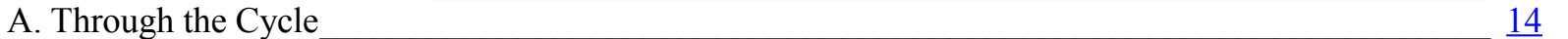

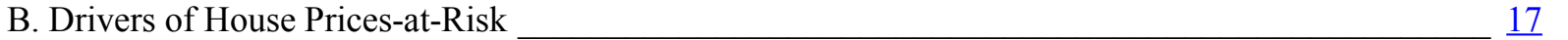

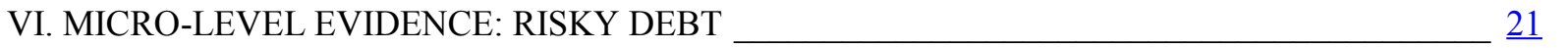

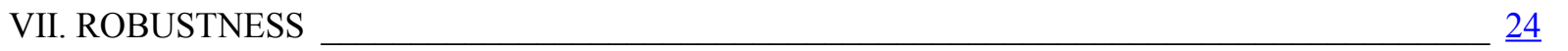

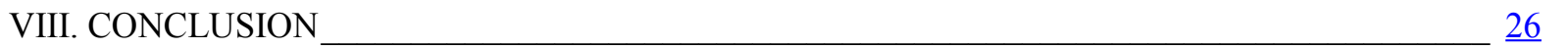

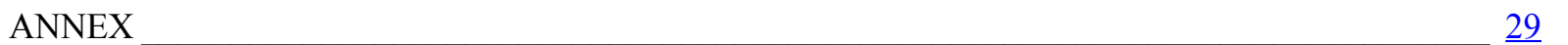

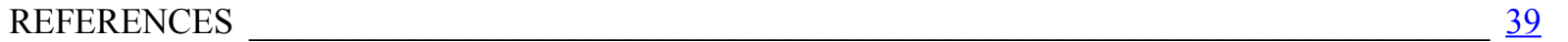
$\square$ 


\section{INTRODUCTION}

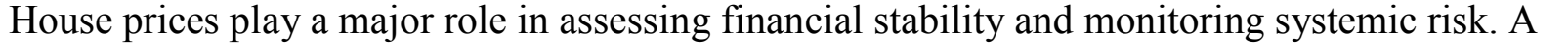

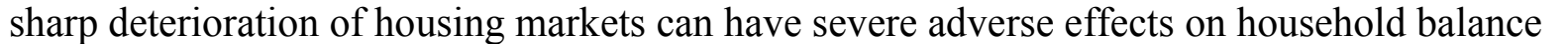

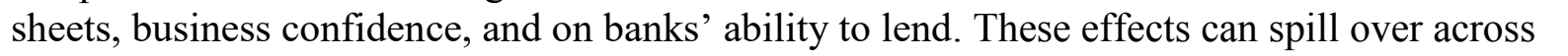

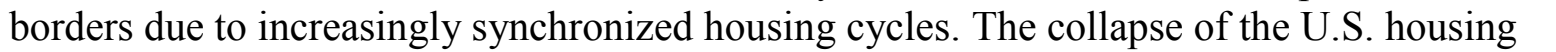

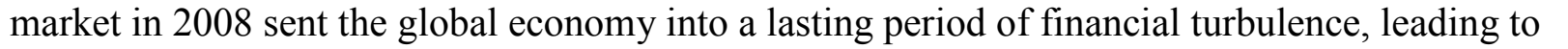

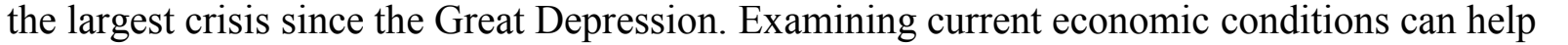
ए $\square$

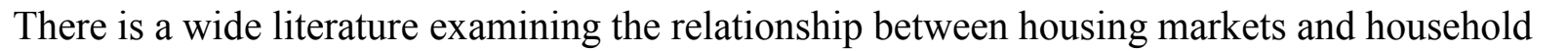

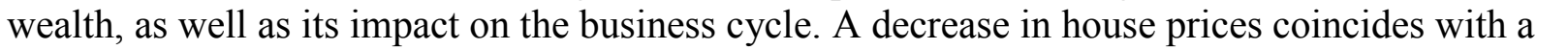

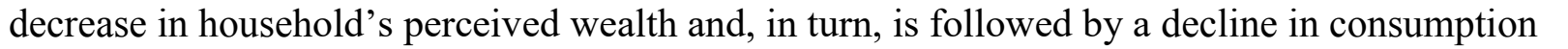

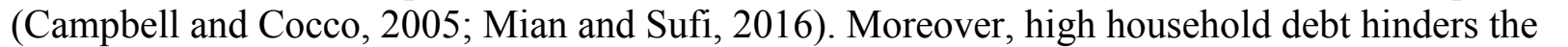

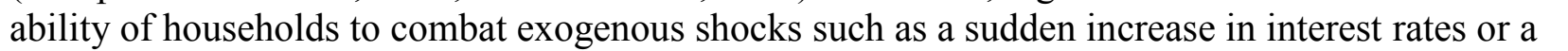
ए

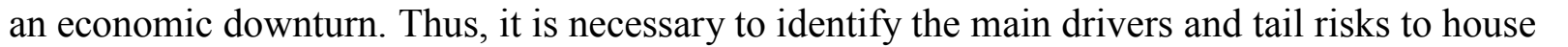

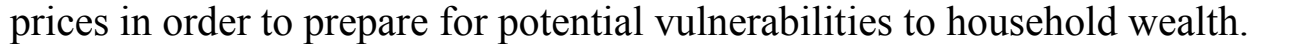

$\square$

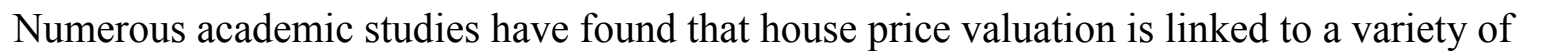

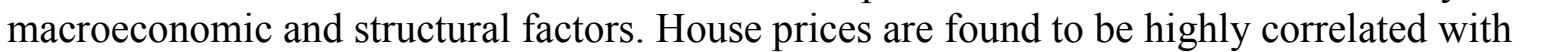

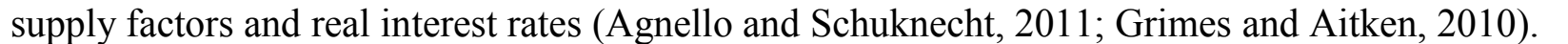

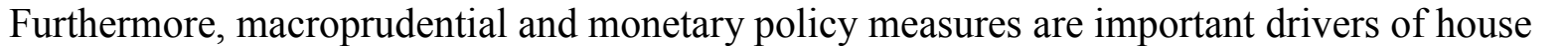

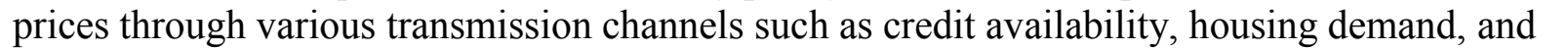

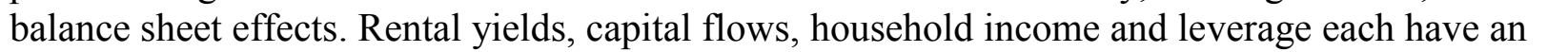

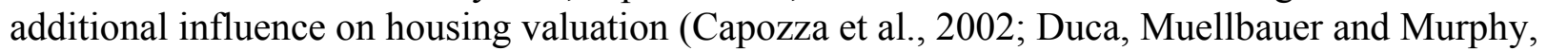
$\square \square \square\|ा\|$

$\square$

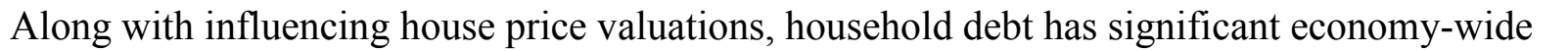

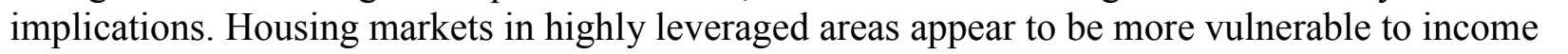

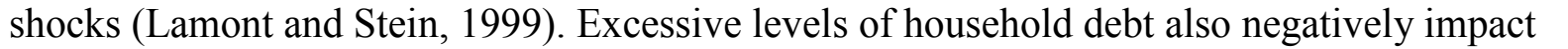
ए

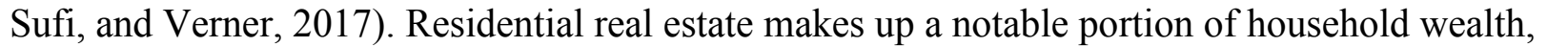

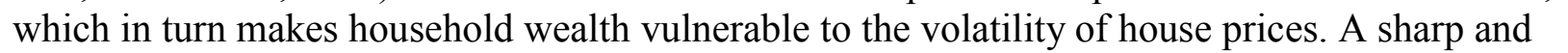
unexpected decrease in house prices impacts household's ability to borrow and consume $\amalg \amalg \square \square$

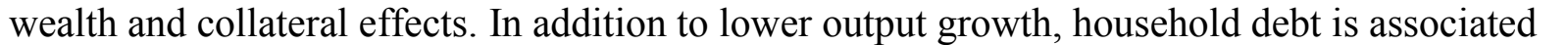

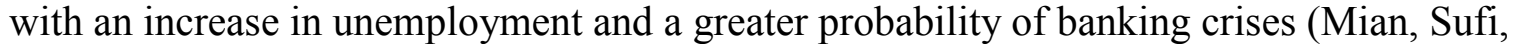

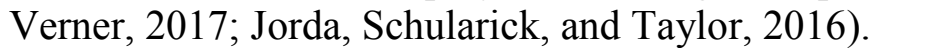

\section{$\square$}

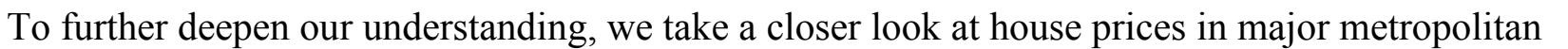

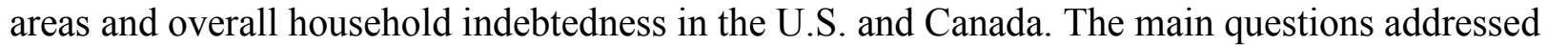

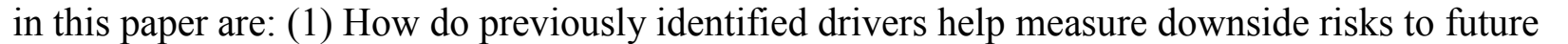

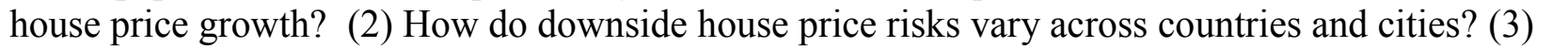

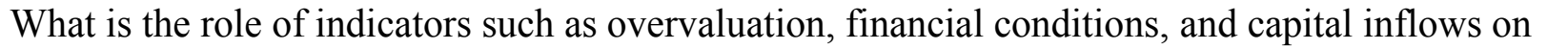

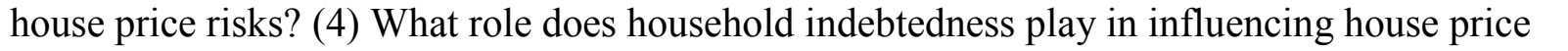

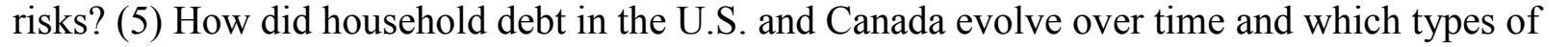

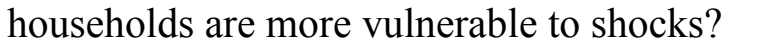




\section{$\square$}

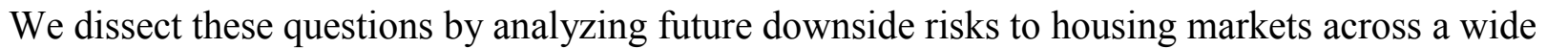

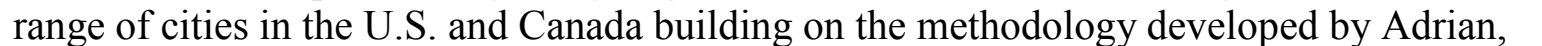

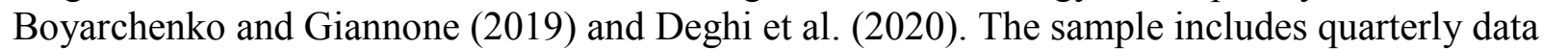

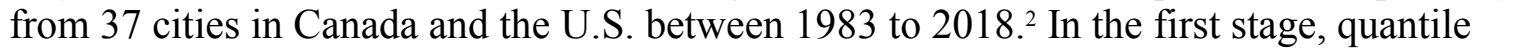
ए

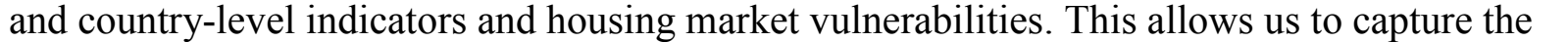

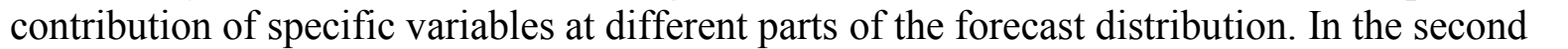

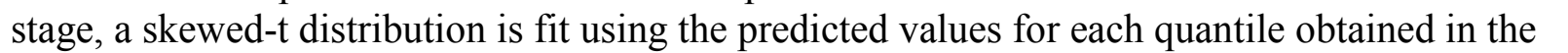

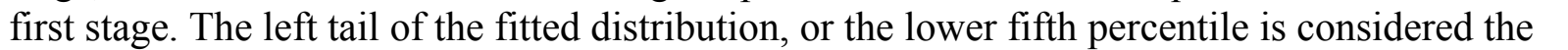

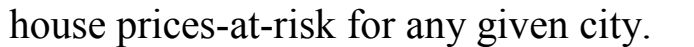

$\square$

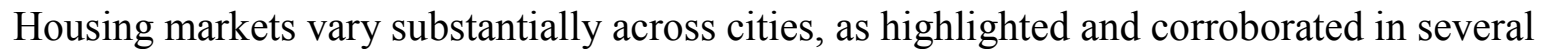

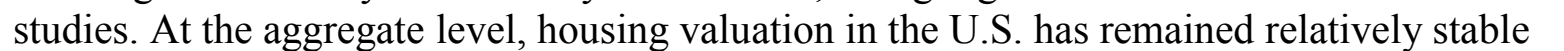

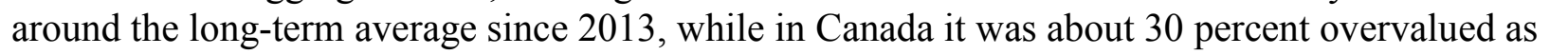

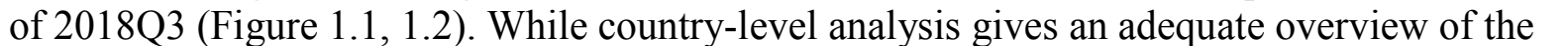

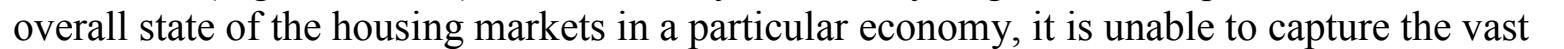

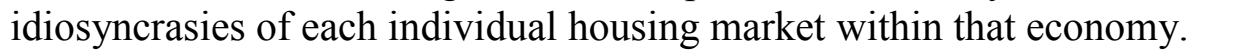

$\square$

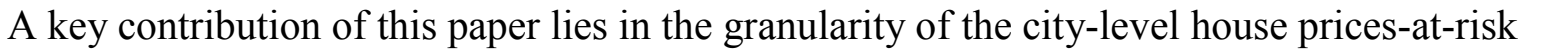

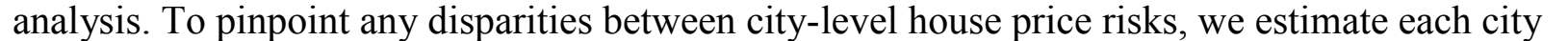

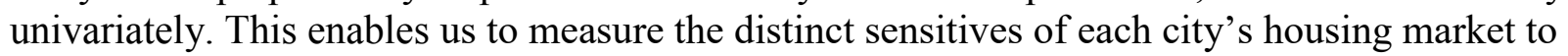

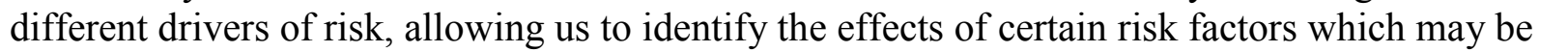

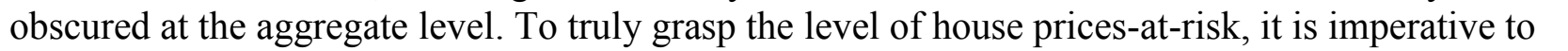

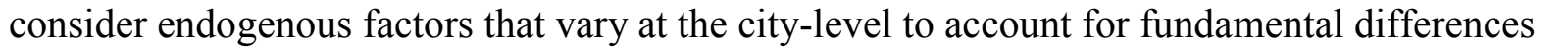

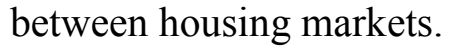

$\square$

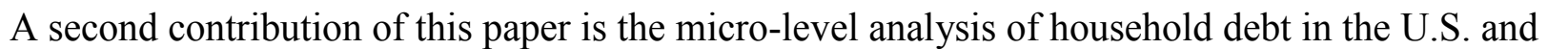

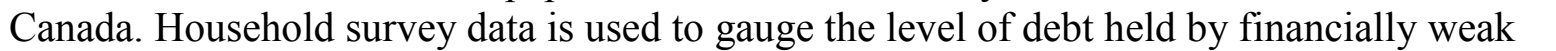

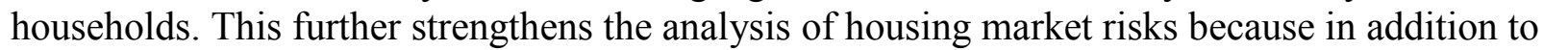

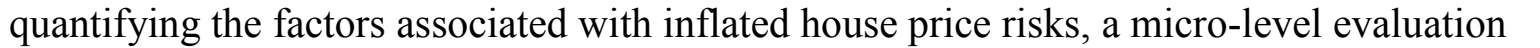

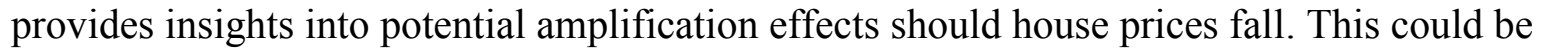

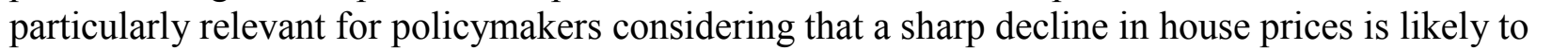

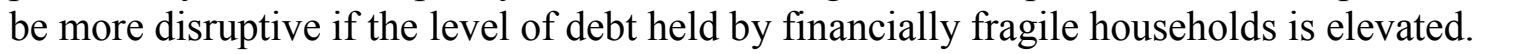

$\square$

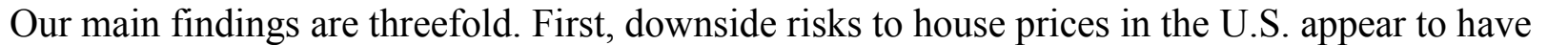

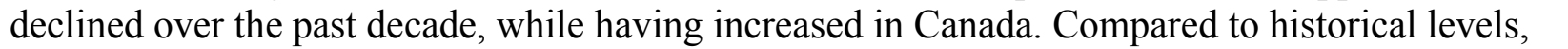
ए

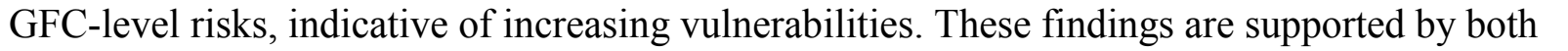
ए

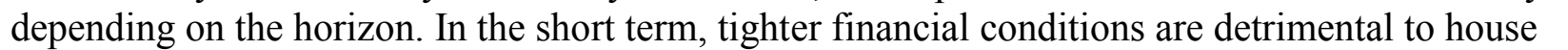

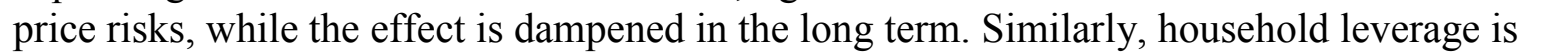

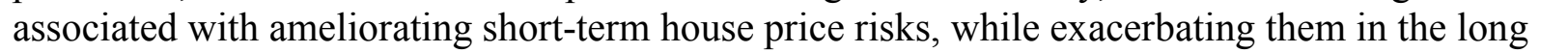

W.1.

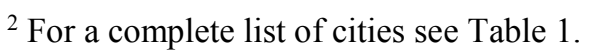

$\square$ 


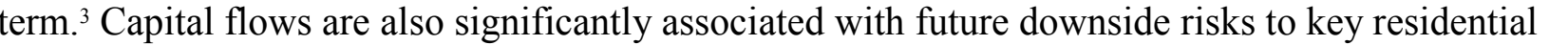

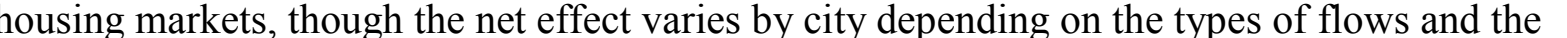

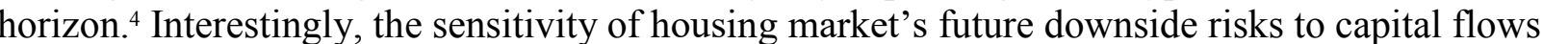

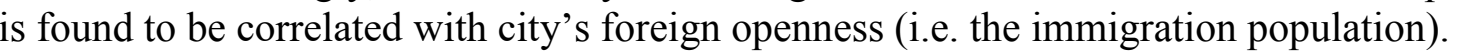

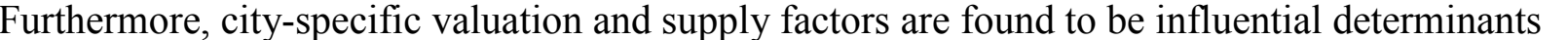

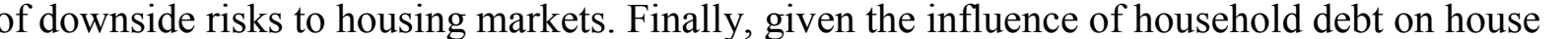

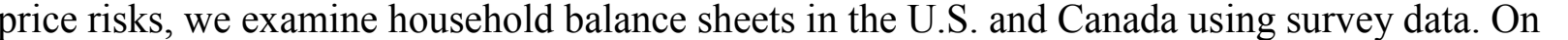

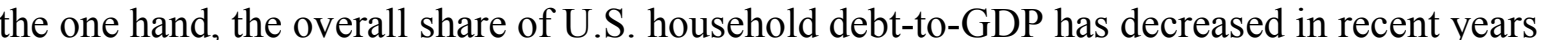

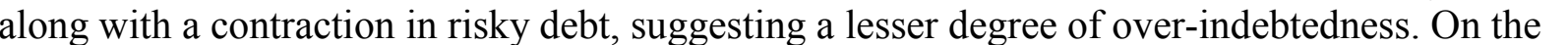

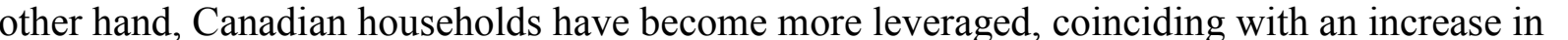

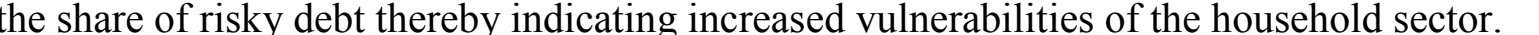
$\square$ 


\section{Figure 1. Overview of Macroeconomic Conditions in the United States and Canada}

1. House Price-to-Income Ratio in the US

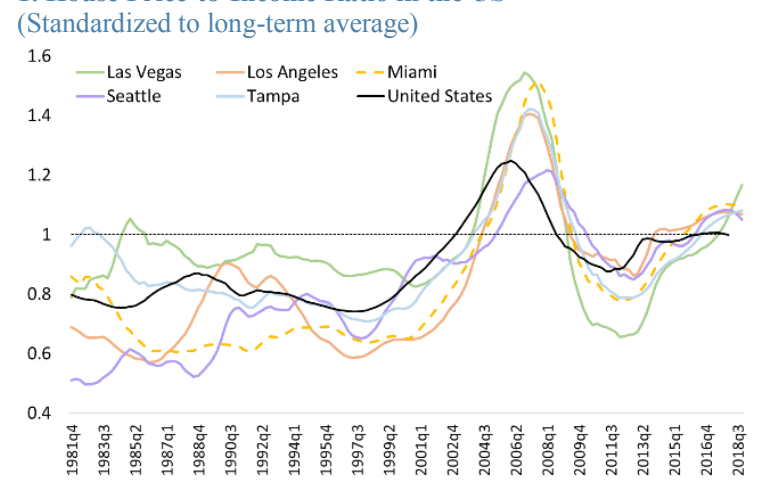

3. Household Debt-to-GDP Ratio and House Prices in the US 120

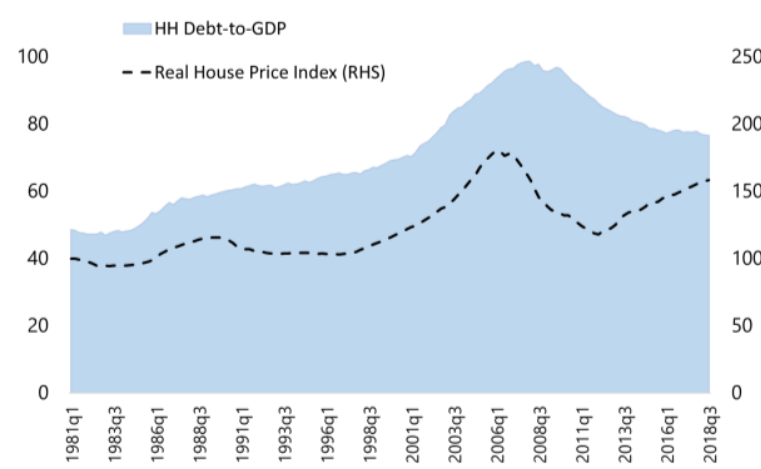

5. Financial Conditions and Mortgage Debt Service in the US$$
2.5
$$

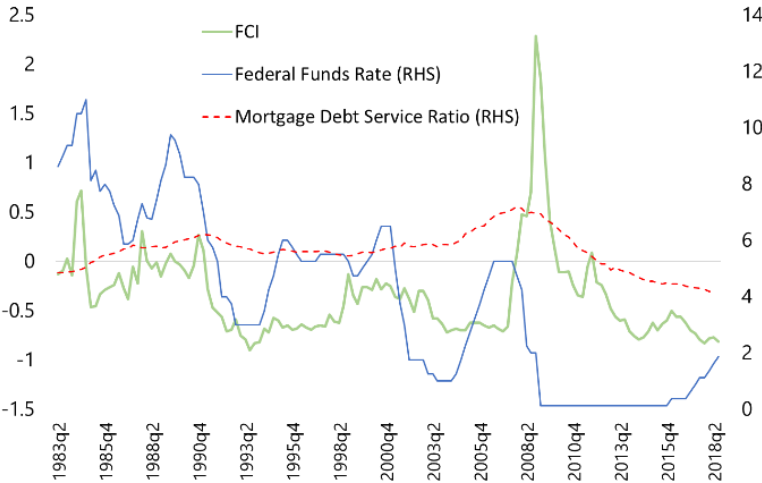

2. House Price-to-Income Ratio in Canada

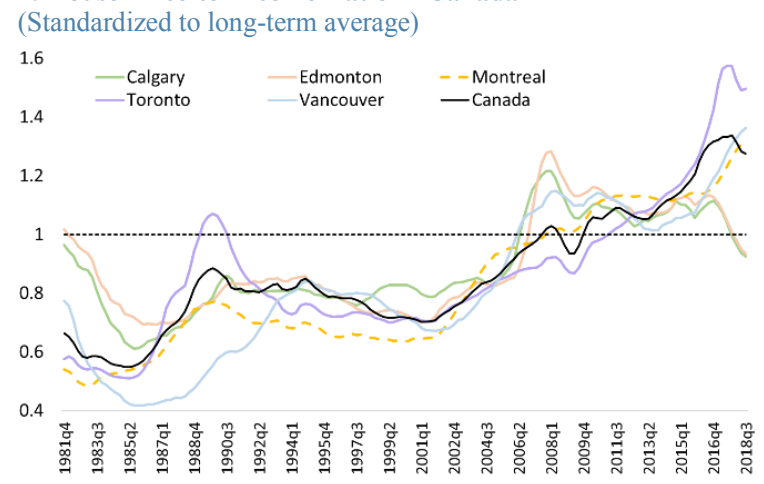

4. Household Debt-to-GDP Ratio and House Prices in Canada 120

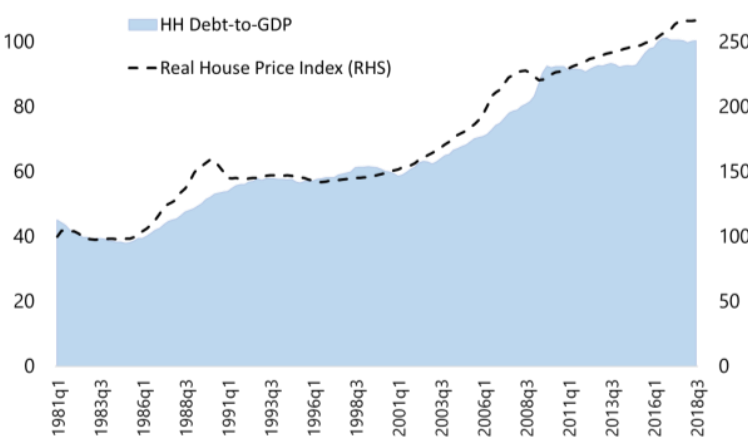

6. Financial Conditions and Mortgage Debt Service in Canada 2.5

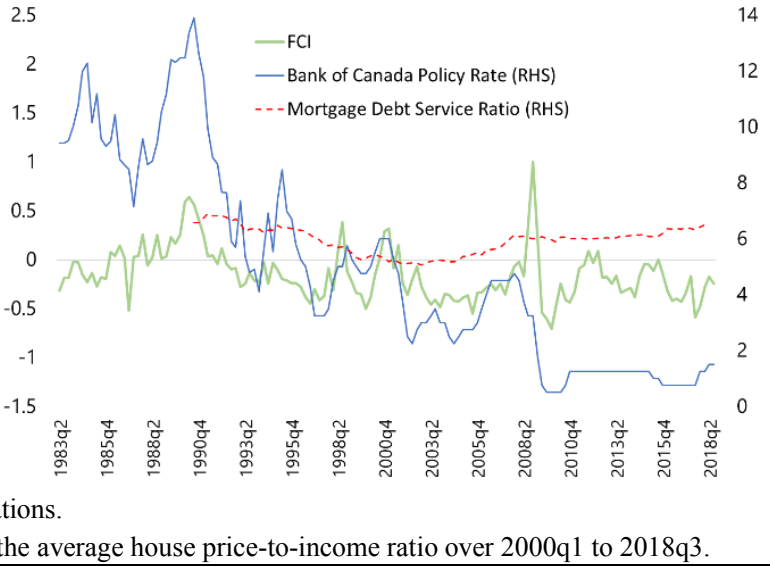




\section{Conceptual Framework}

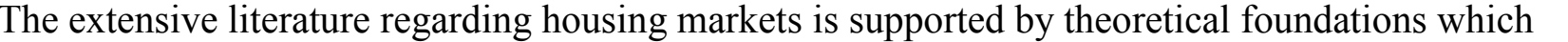

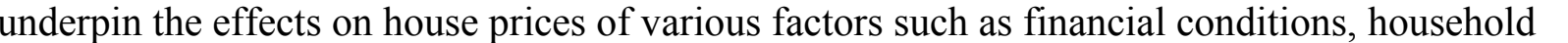

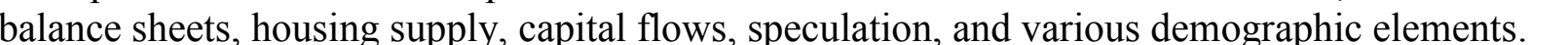

\section{A. Financial Conditions}

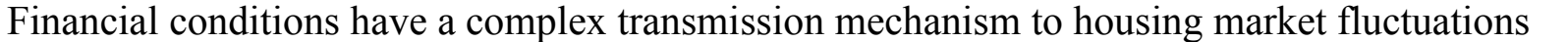
प

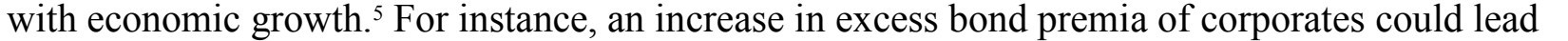

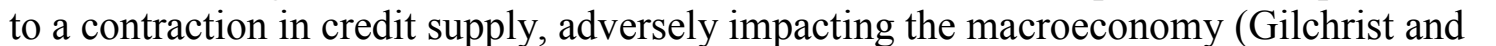

Zakrajšek

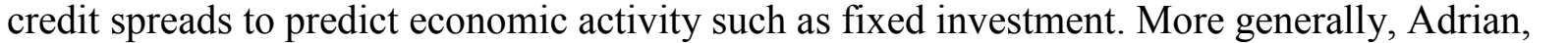

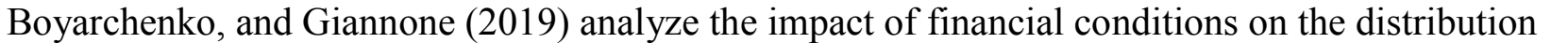

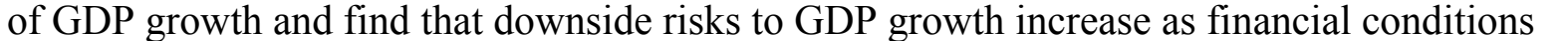

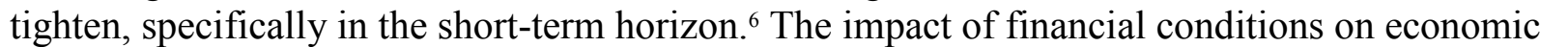

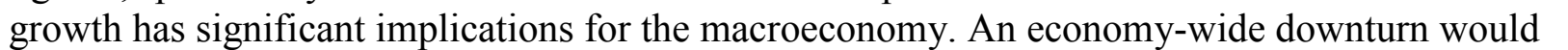
ए

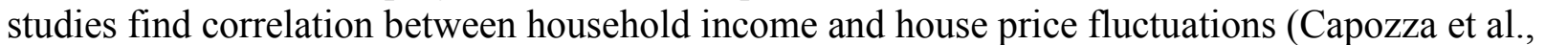

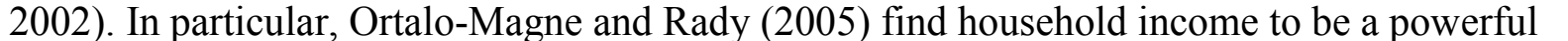
driver of the housing market, asserting that income strongly influences younger households'

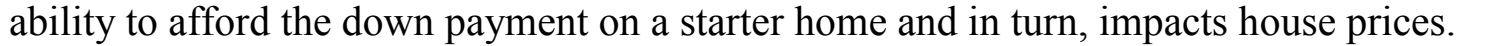

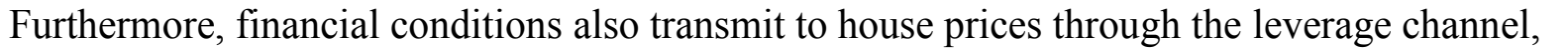

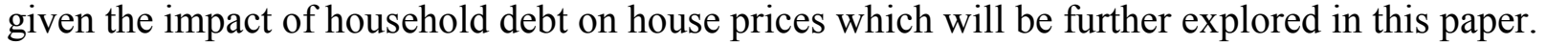

\section{B. Household Debt}

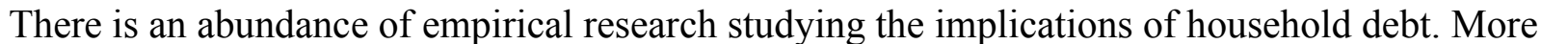

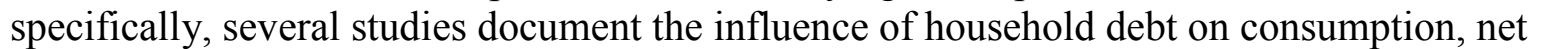

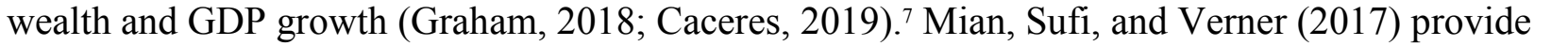

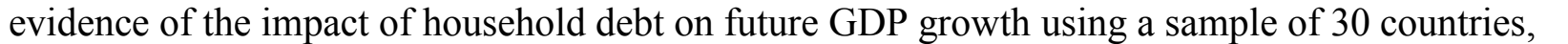

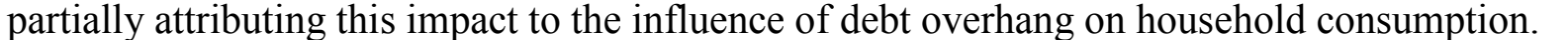

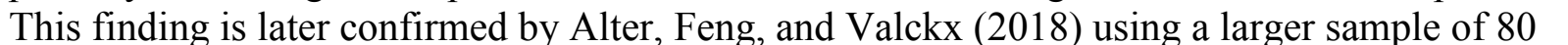

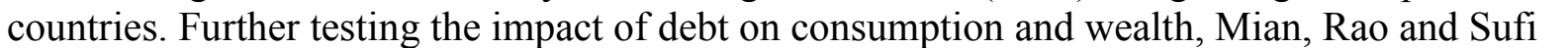

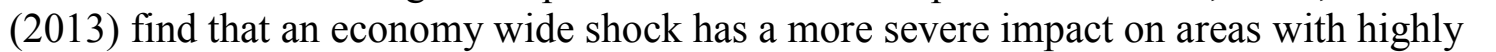

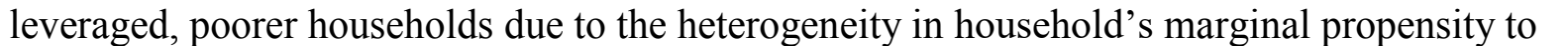

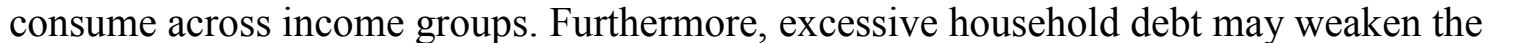

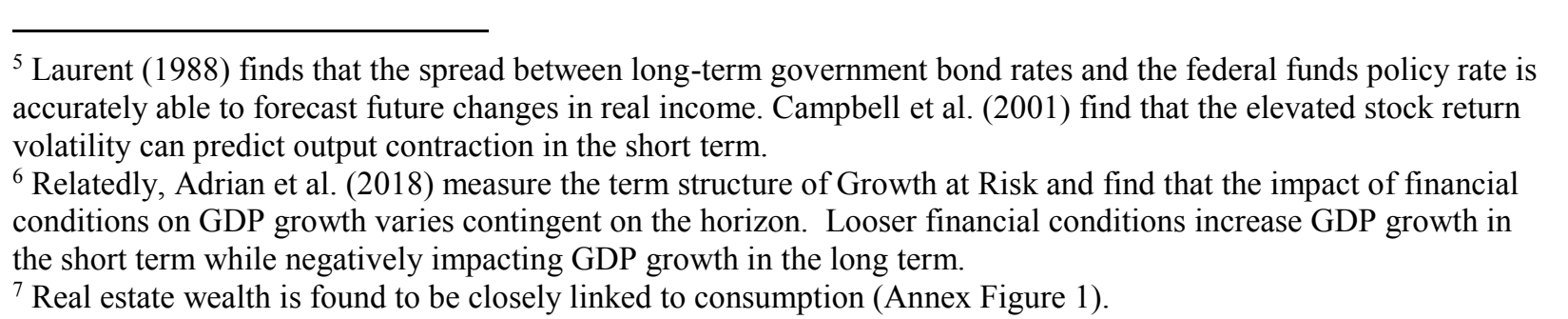




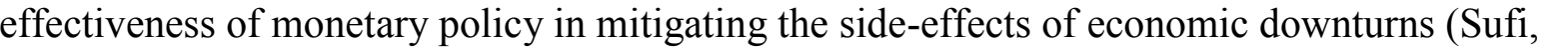

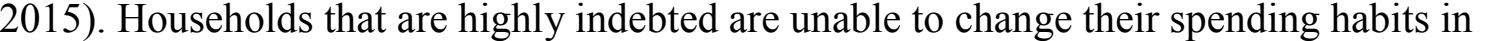

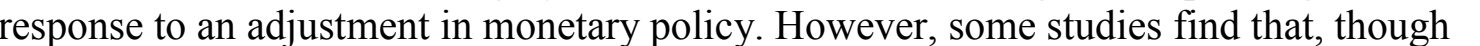

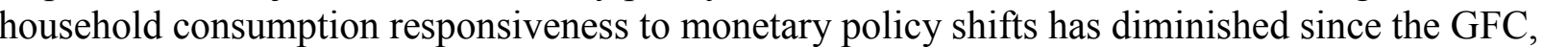

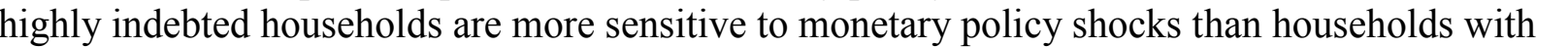

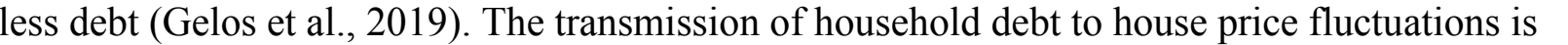

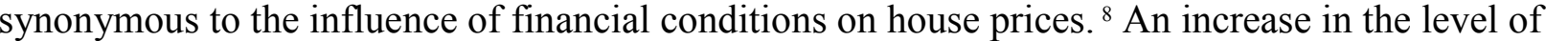

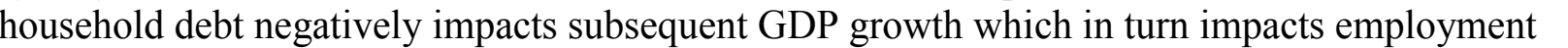

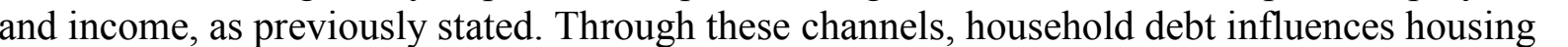
$\square \square \square \square ा \| ा प$

$\square \quad \square$

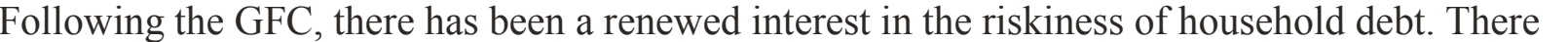

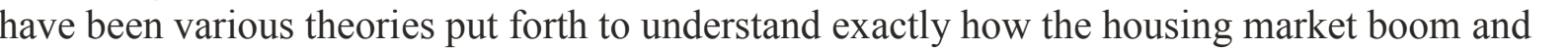

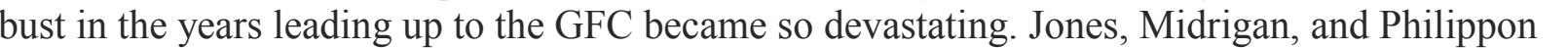

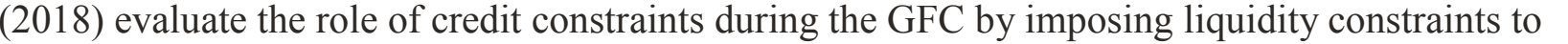
प एम

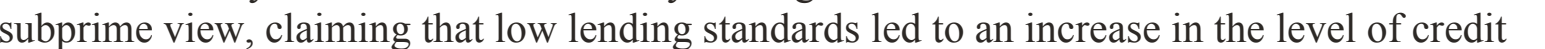

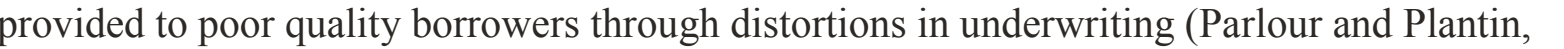

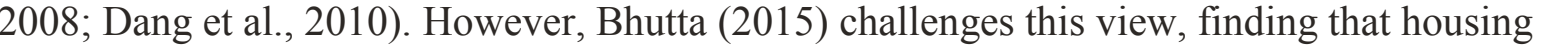

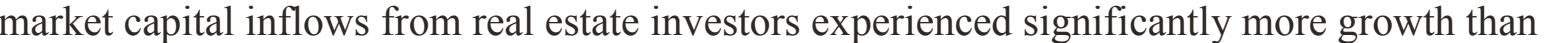
प

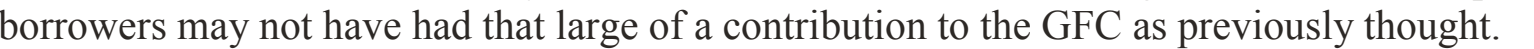

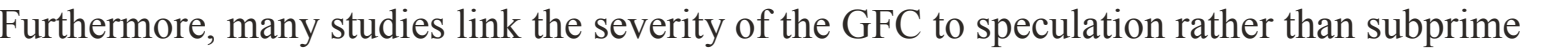

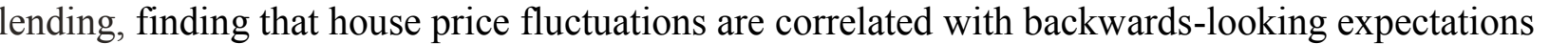

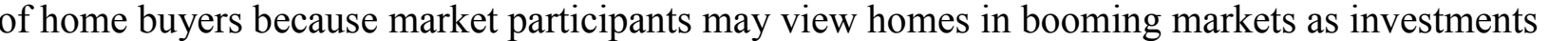

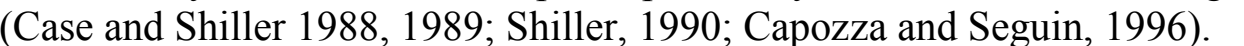
$\square$

\section{Capital Flows}

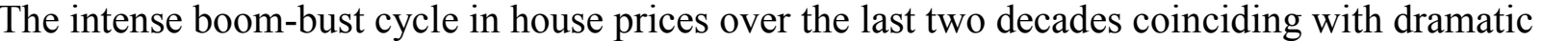

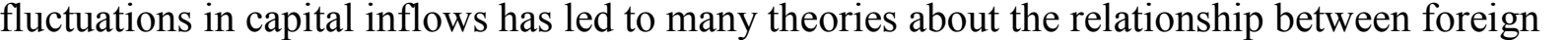

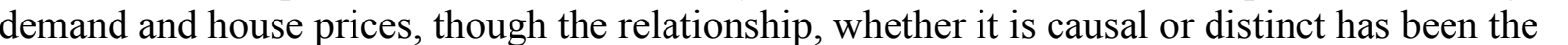

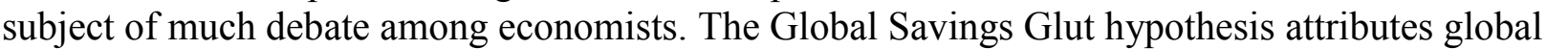

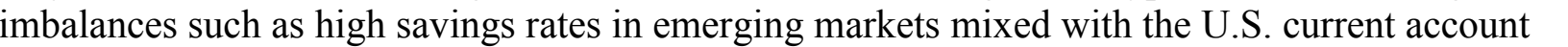

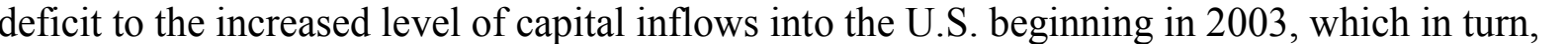

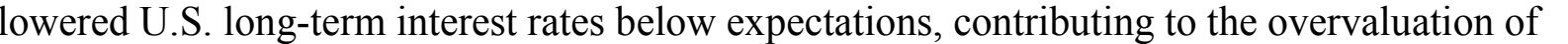

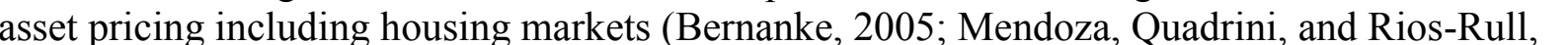

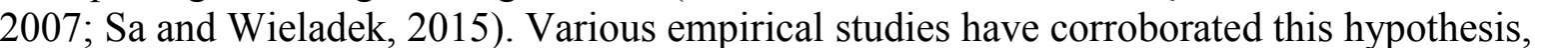

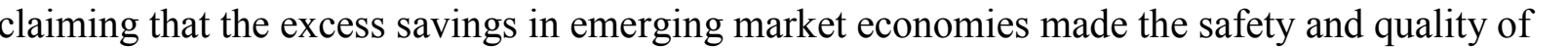

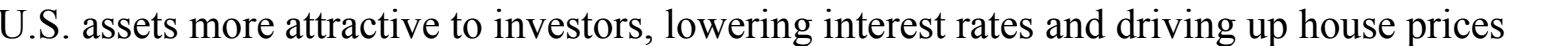

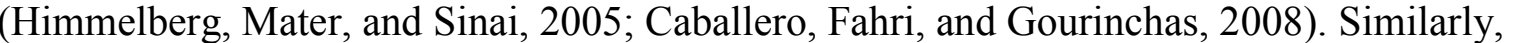

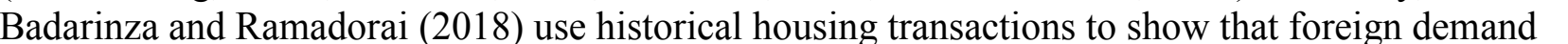

\section{m}

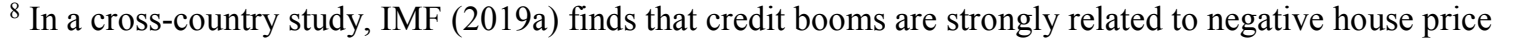

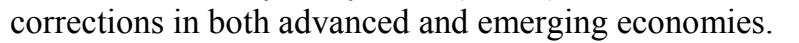




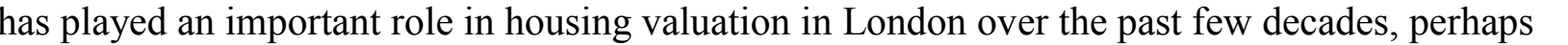

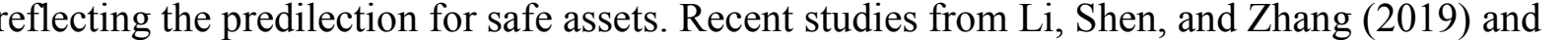

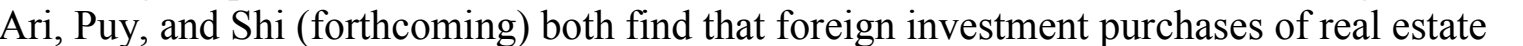

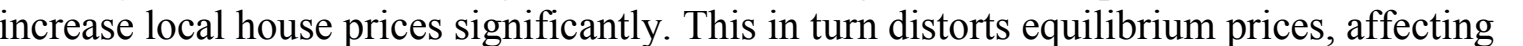

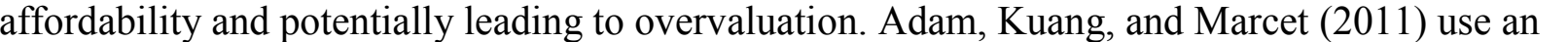

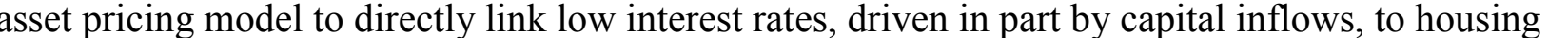

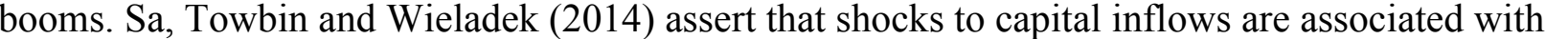

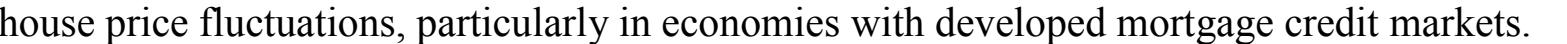

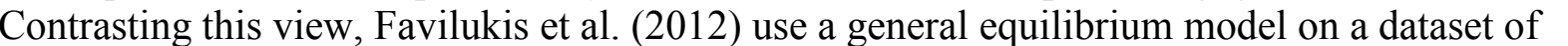

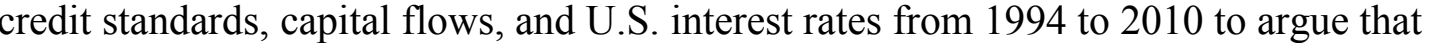

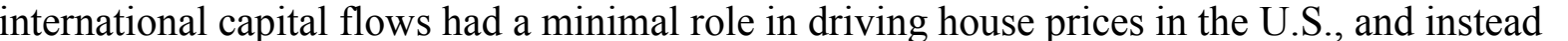

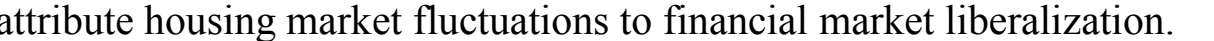

\section{Other Key Indicators}

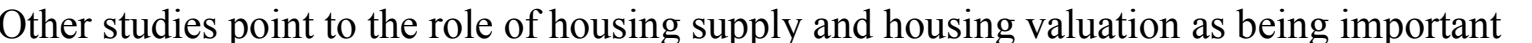

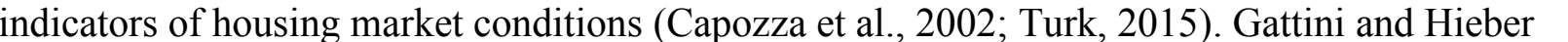

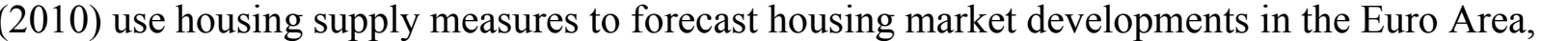

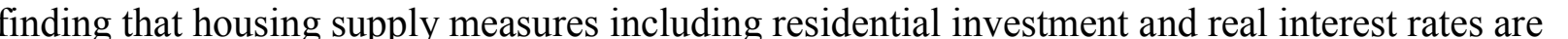

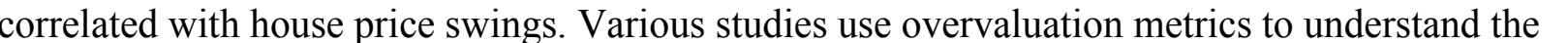

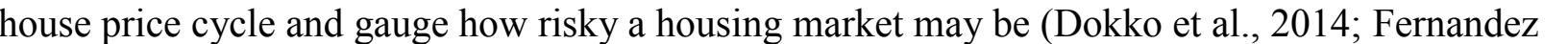

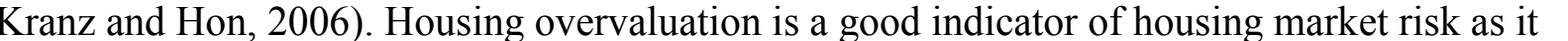

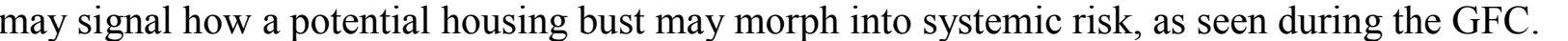

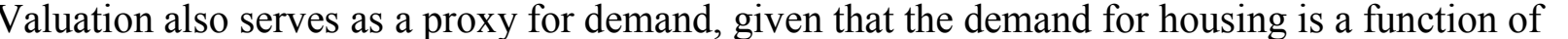

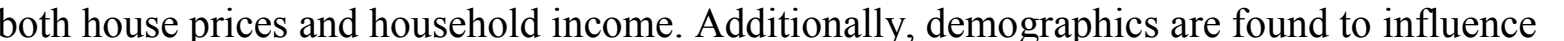

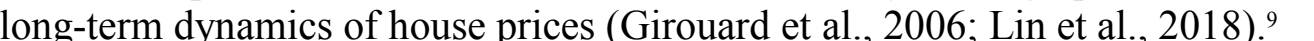
$\square$

\section{STYLIZED FACTS}

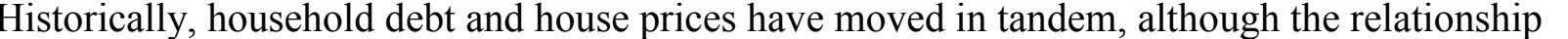

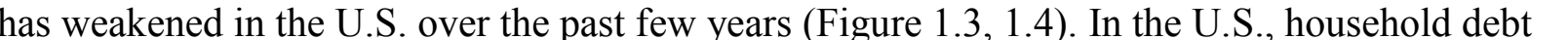

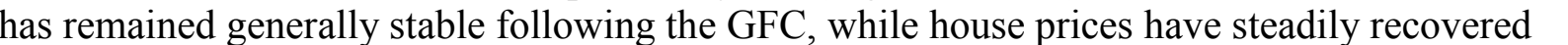

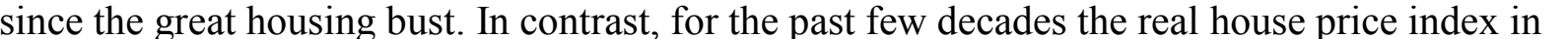

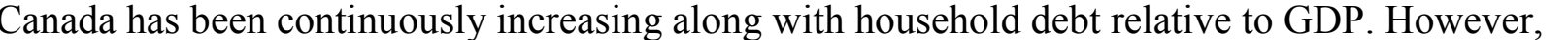

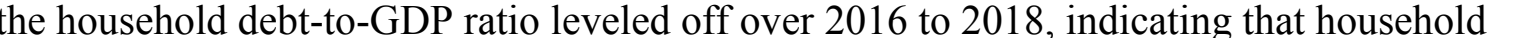

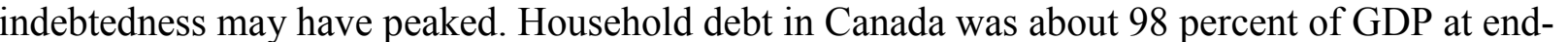

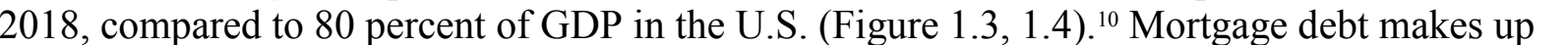

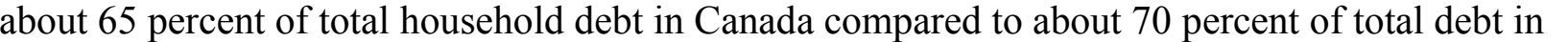

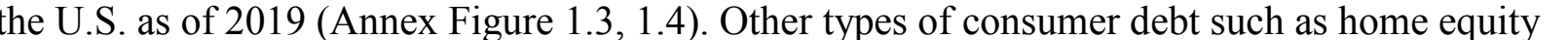

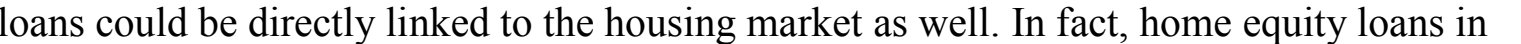

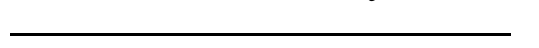

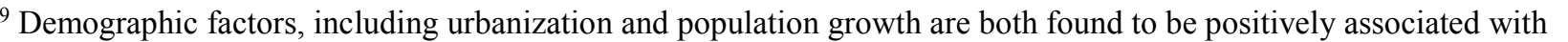

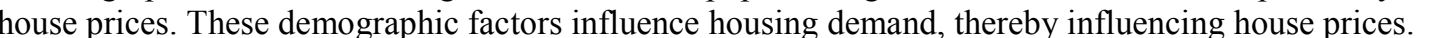

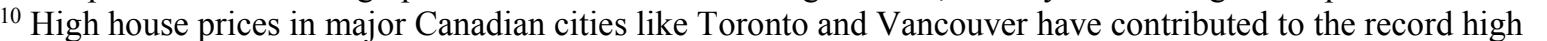

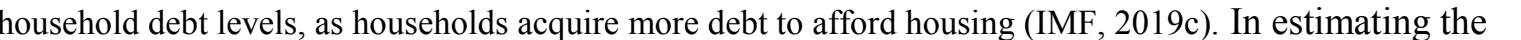

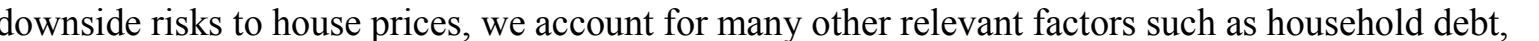

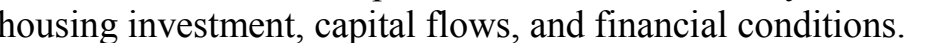

$\square$ 


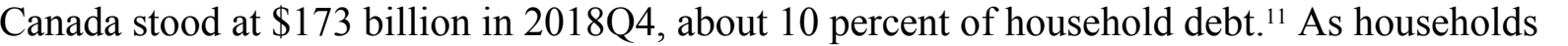

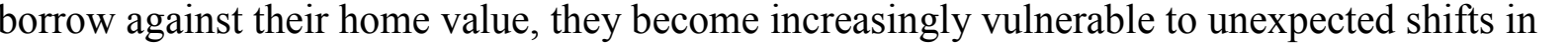

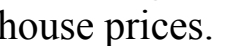

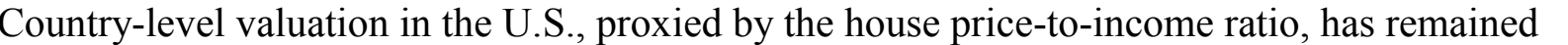

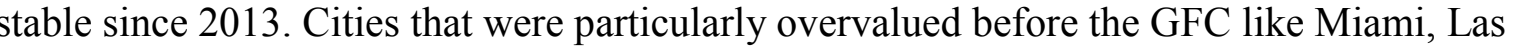

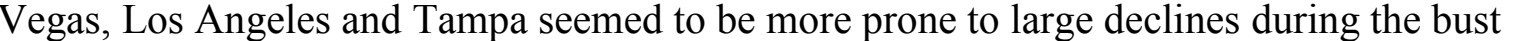

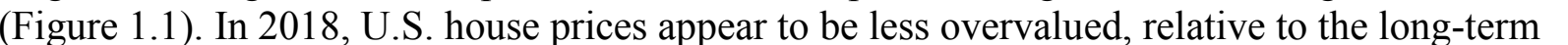

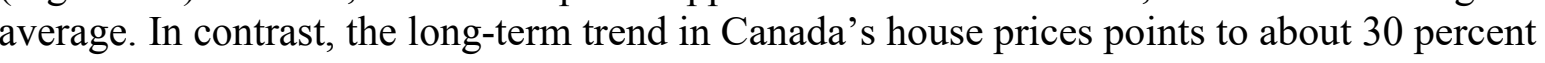

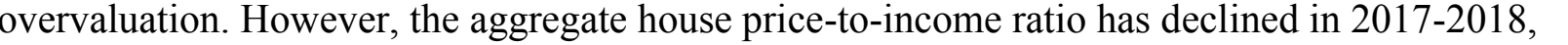

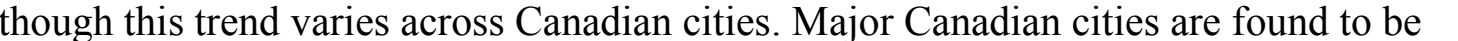

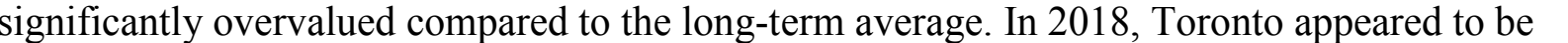

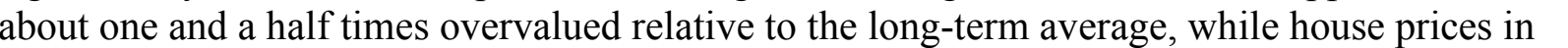

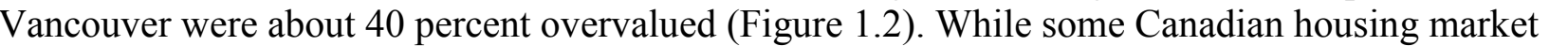

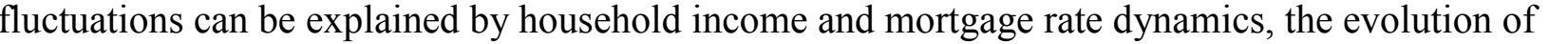

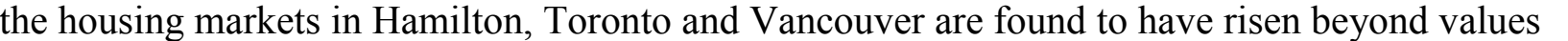

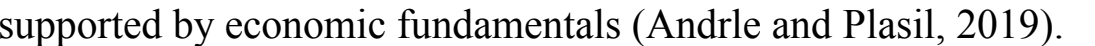

$\square$

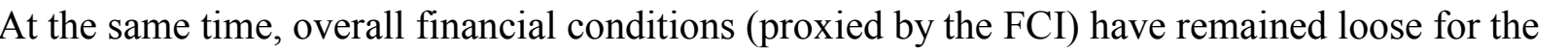

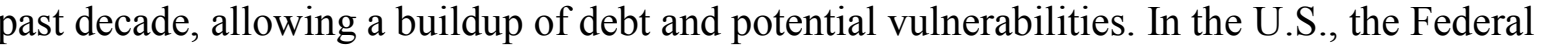

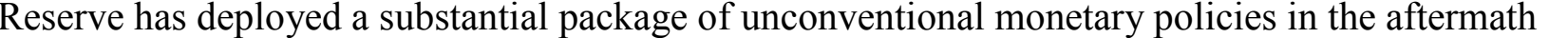

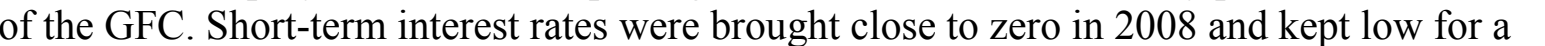

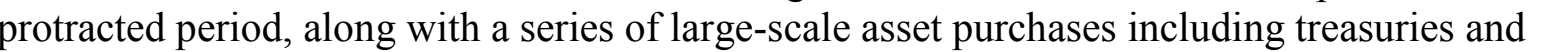

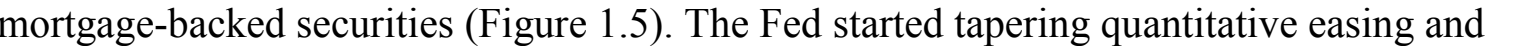

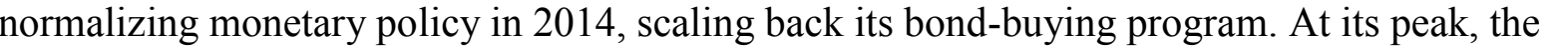

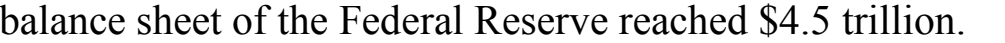

$\square$

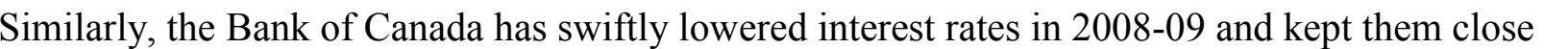

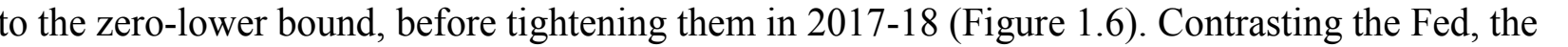

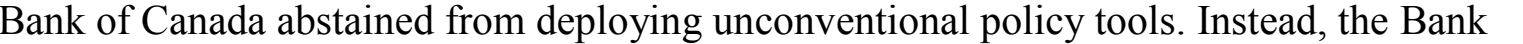

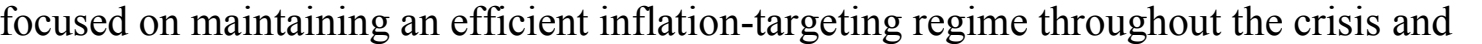

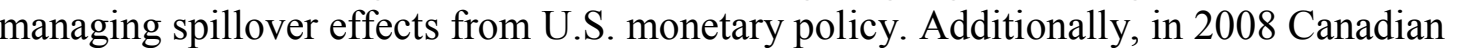

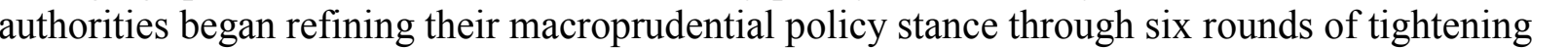

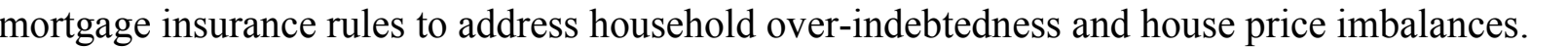

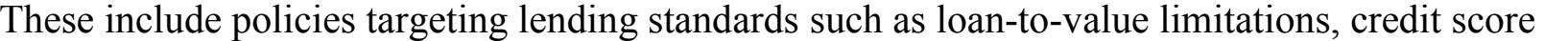
ए

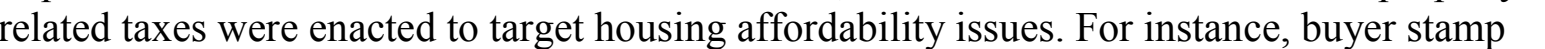

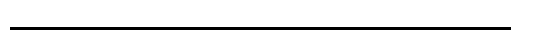

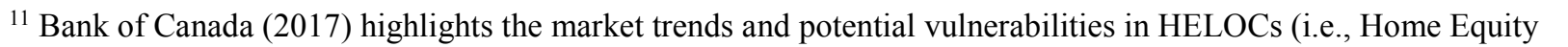

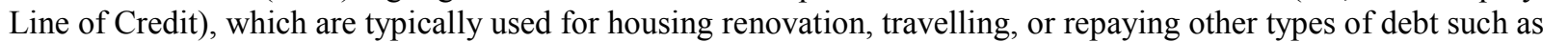

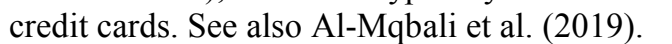

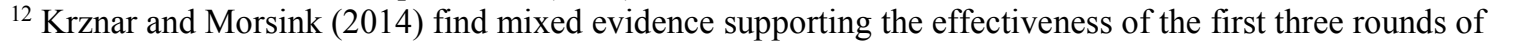

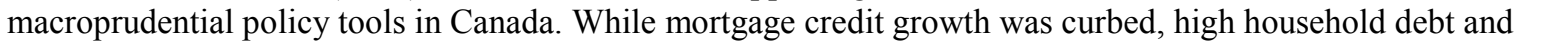

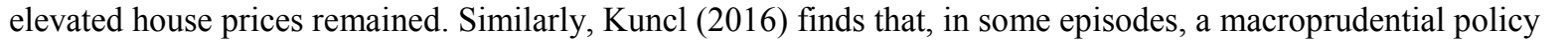

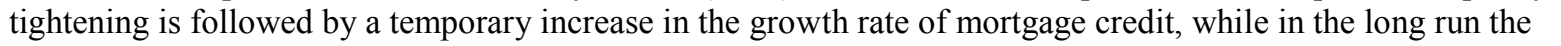

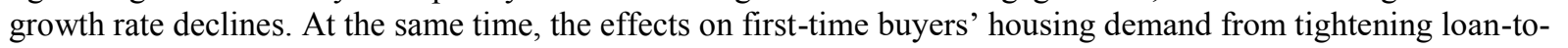

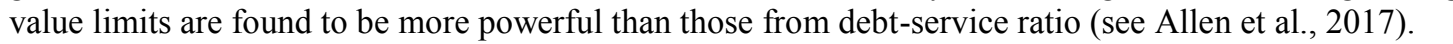
$\square$ 


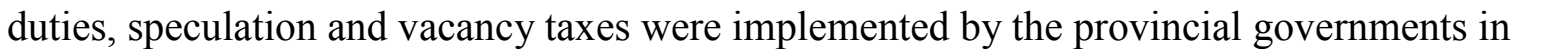

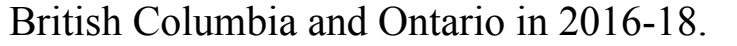

$\square$

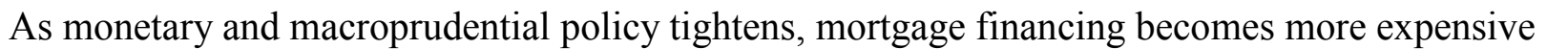

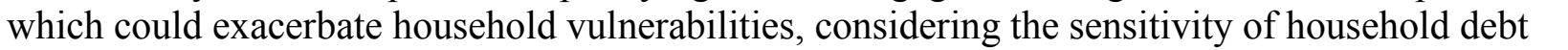

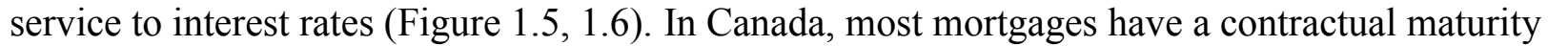

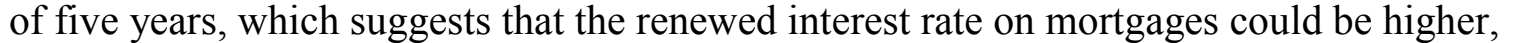

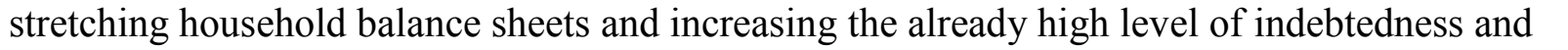

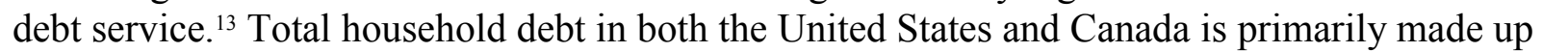

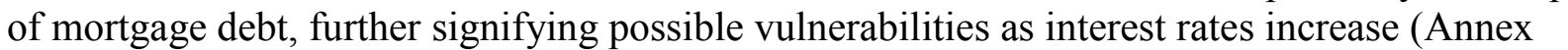

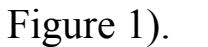

$\square$

\section{DAta AND EMPirical ANALYsis}

\section{A. Data}

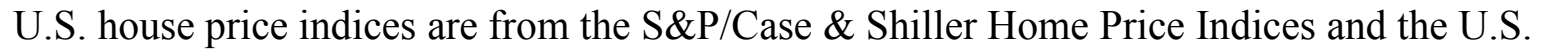

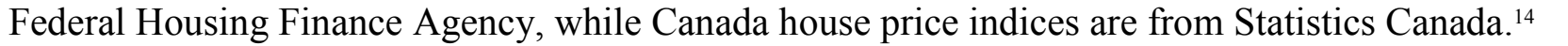

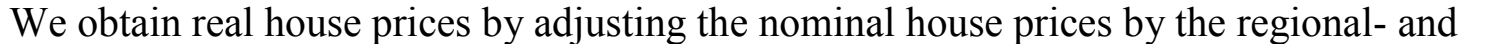

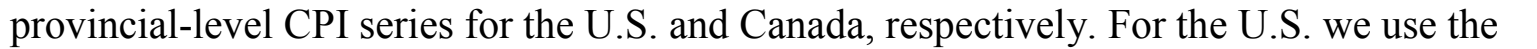

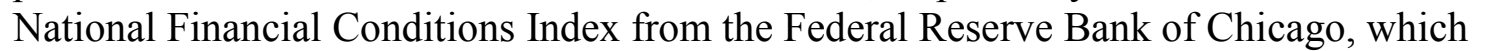
ए ए

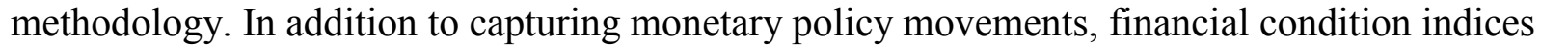

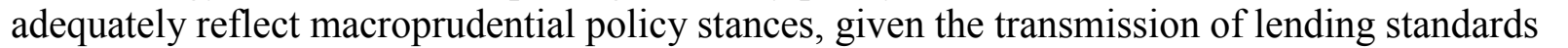

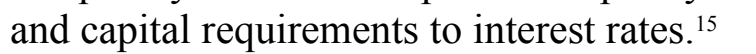

$\square$

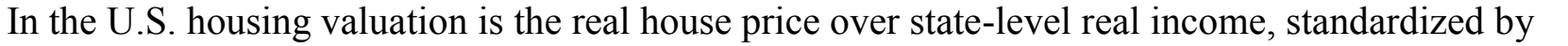

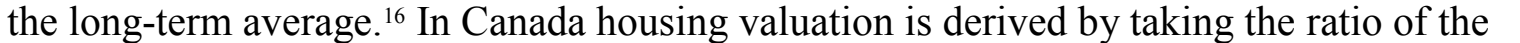

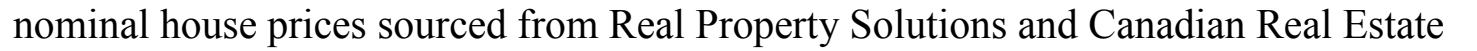

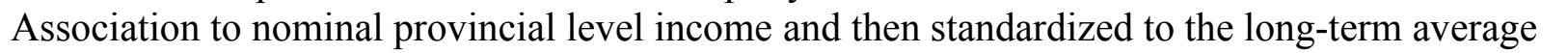

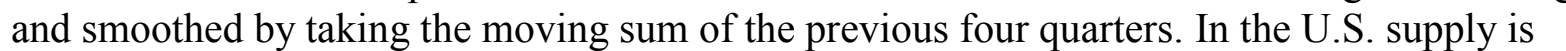

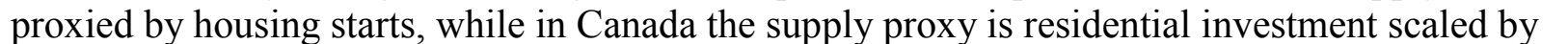

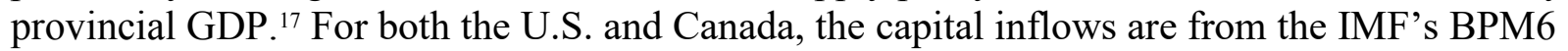

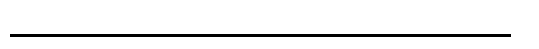

(1)

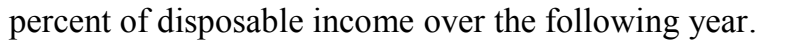

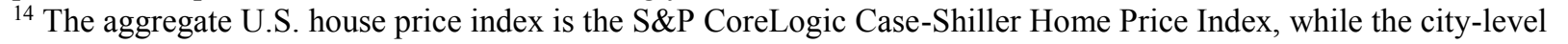
प

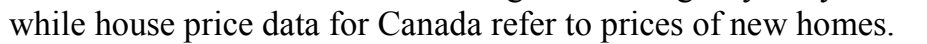

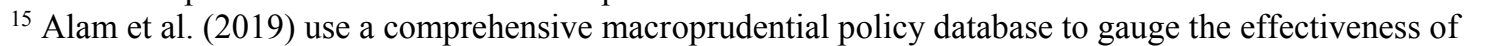

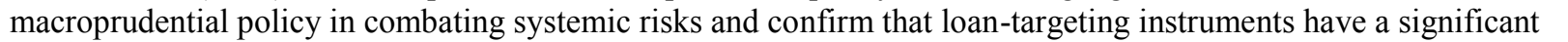

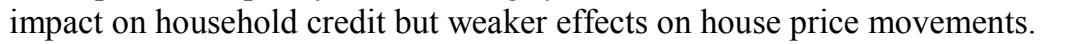

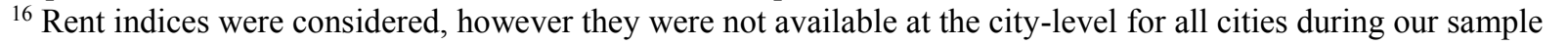

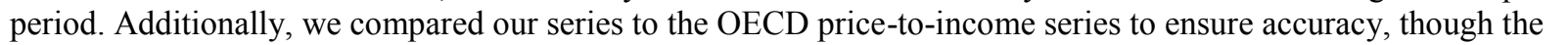

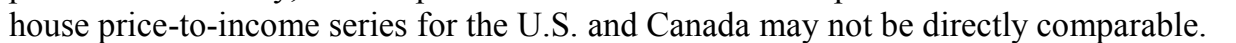

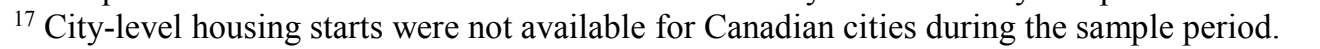
$\square$ 


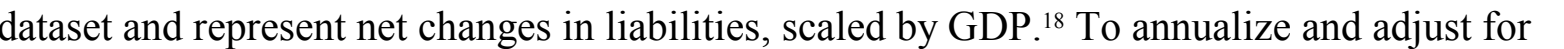

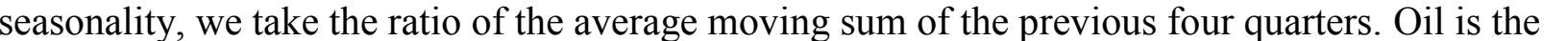

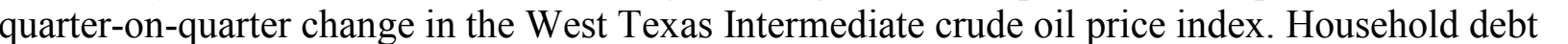
ए

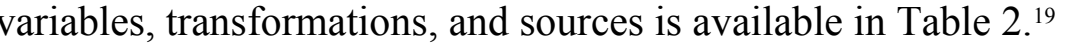

$\square$

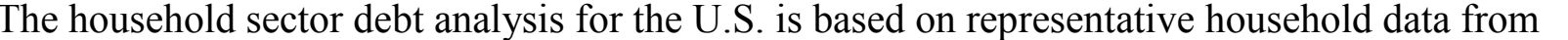

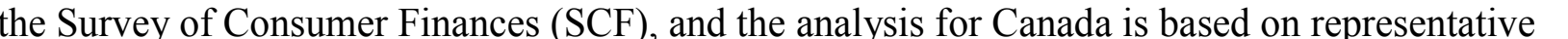

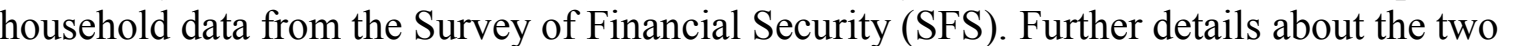

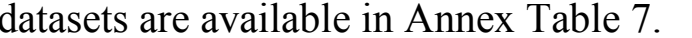

\section{B. Empirical Approach}

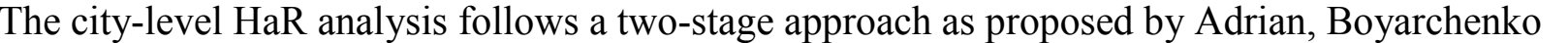

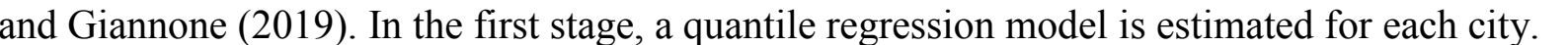

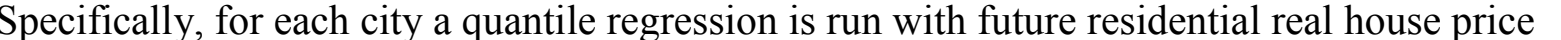

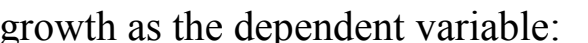

$$
\Delta C i t y H P_{c, i, t+h}^{q}=\beta X_{c, i, t}+\delta Z_{c, t}+\gamma O i l_{t}+\phi F C I_{c, t}+\varepsilon_{c, i, t}
$$

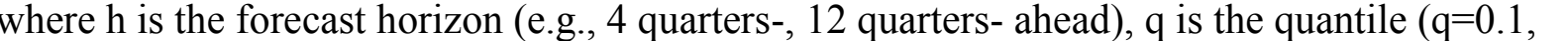

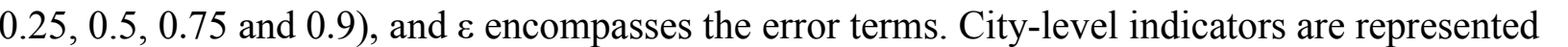

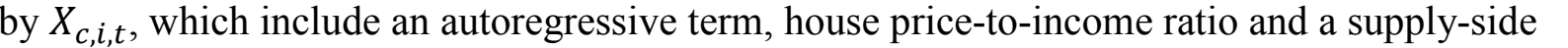

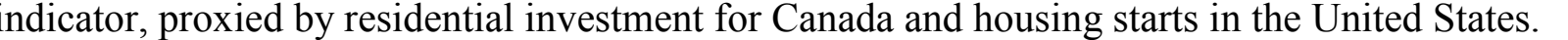

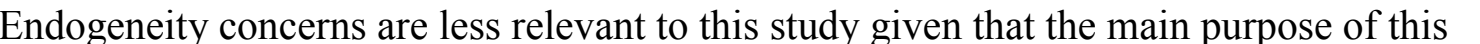

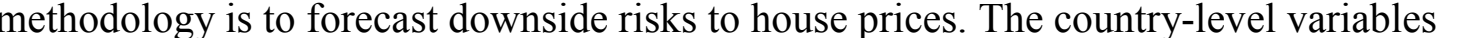

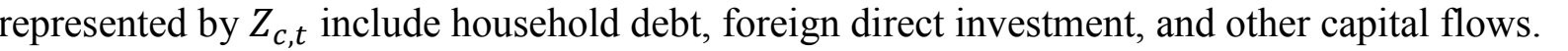

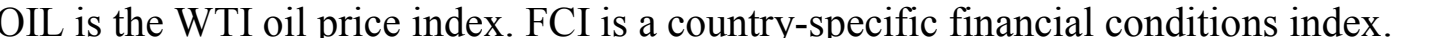

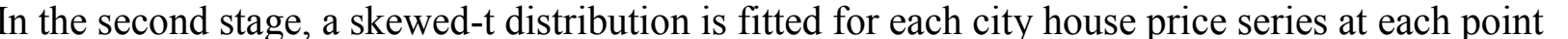

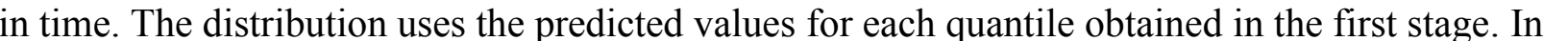

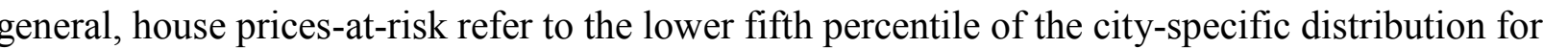

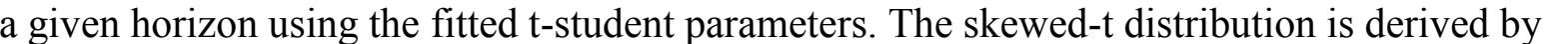

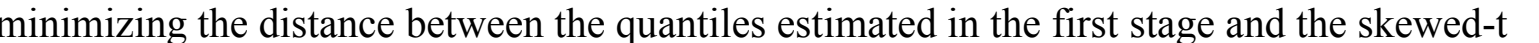

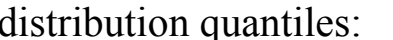

$$
\operatorname{loc}^{*}, \text { scale }^{*}, \text { skew }^{*}=\operatorname{argmin}\left[\sum_{q} \text { tskew.quantile }\left(q, \text { loc }, d f^{*}, \text { scale, skew }\right)-Q\left[y_{t+h}^{q}\right]^{2}\right] \square
$$

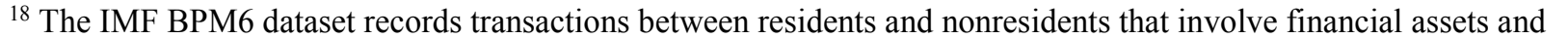

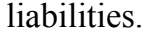

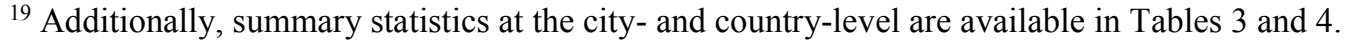




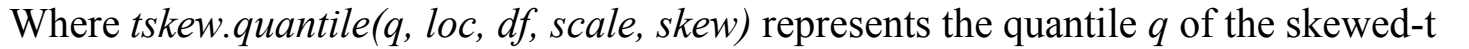

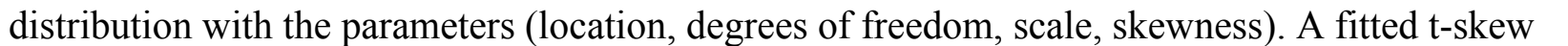

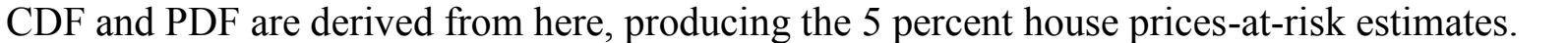

$\square$

\section{EMPIRICAL FINDINGS}

\section{A. Through the Cycle}

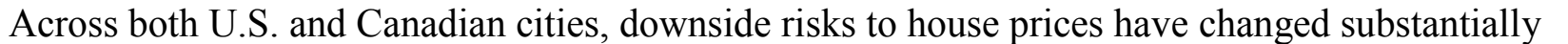

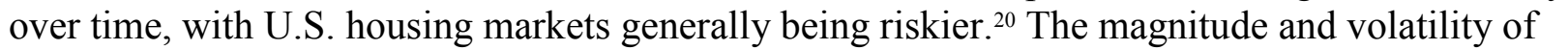

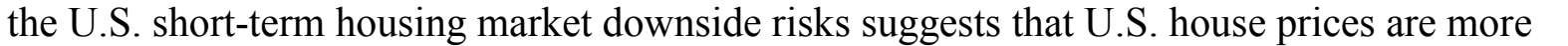

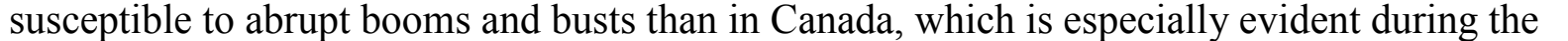

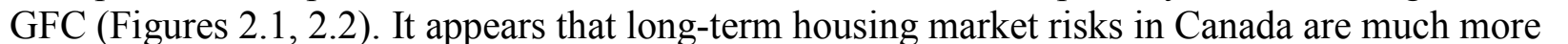

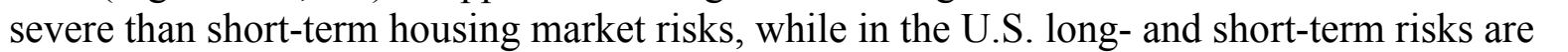

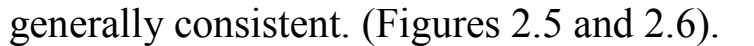

$\square$

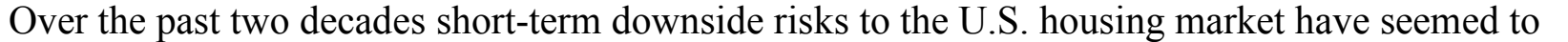

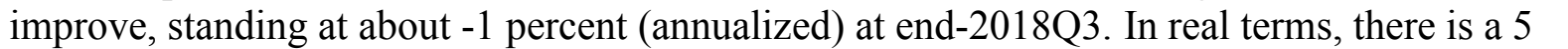

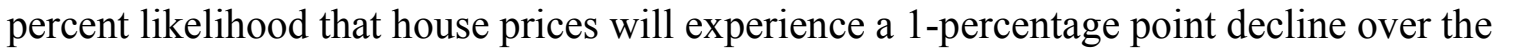

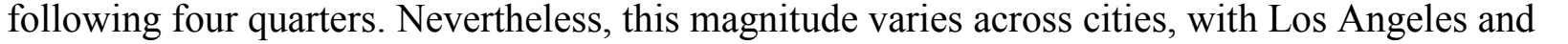

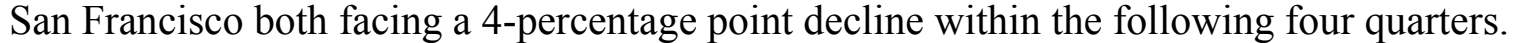

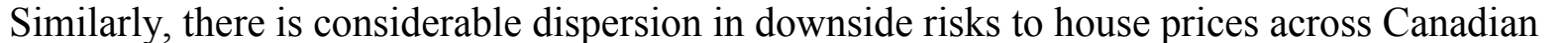

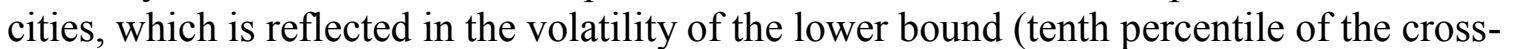

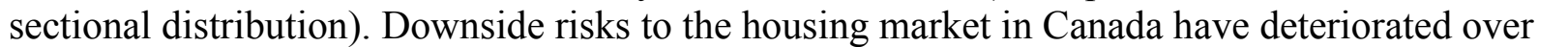
ए

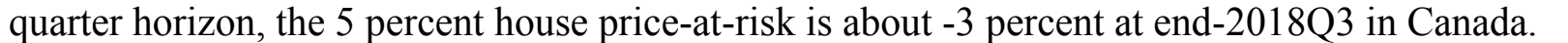

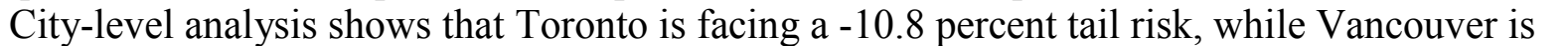

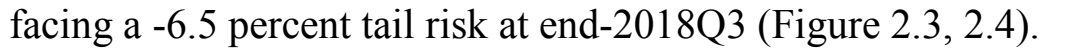

\section{$\square$}

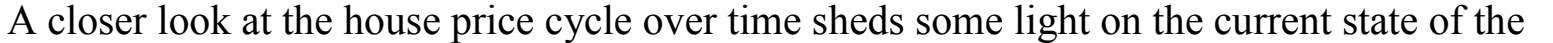

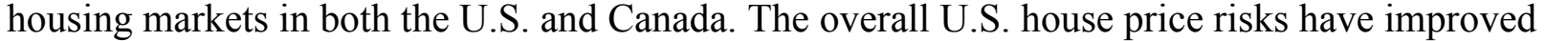

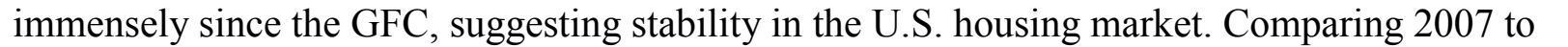

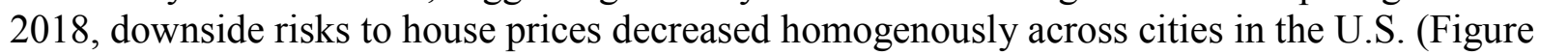

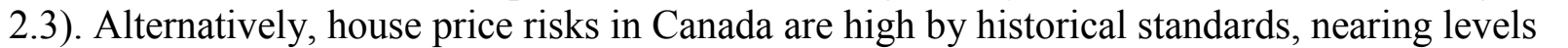

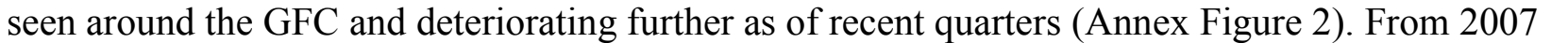
ए

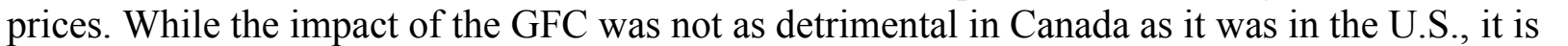

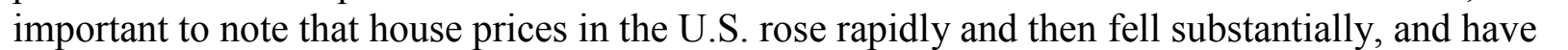

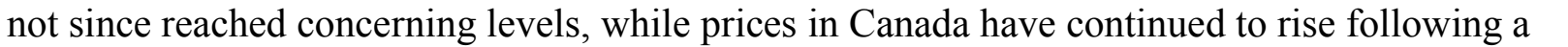

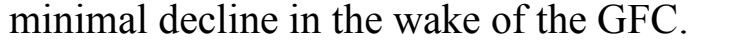

$\square$

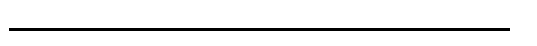

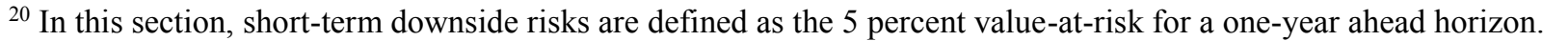

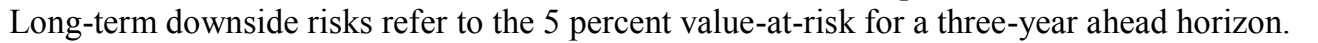




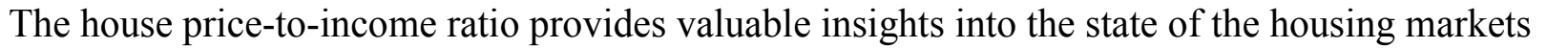

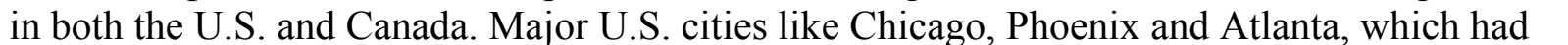

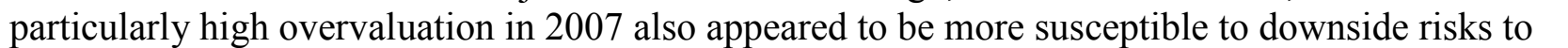

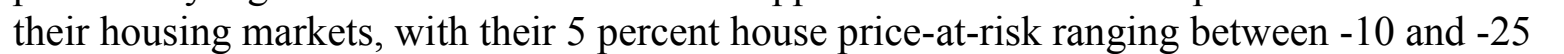

percent right before the GFC. This contrasts notably to 2018 when each city's house price

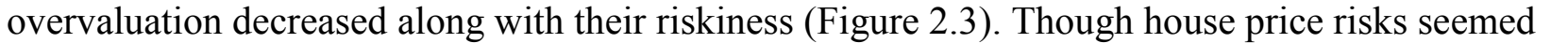

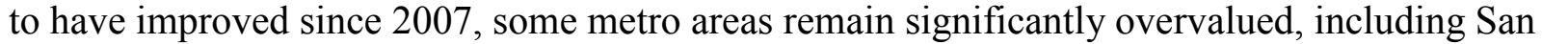

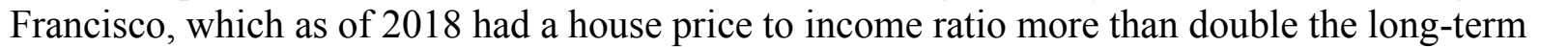

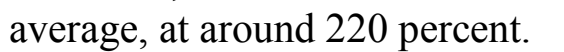

$\square$

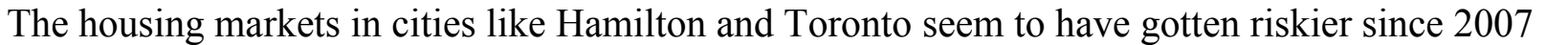

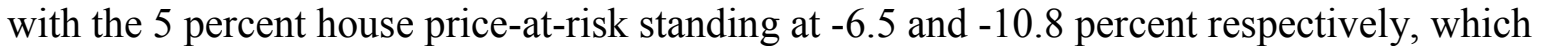

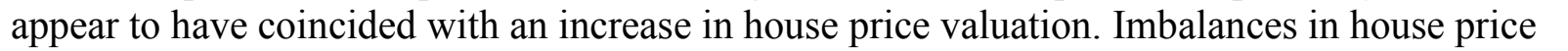

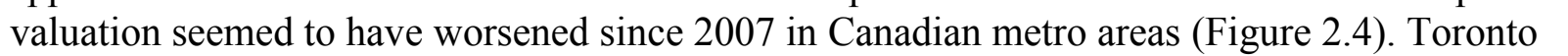

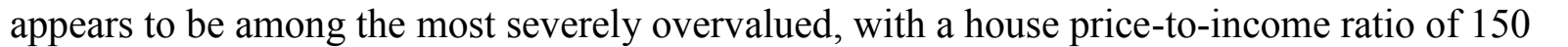

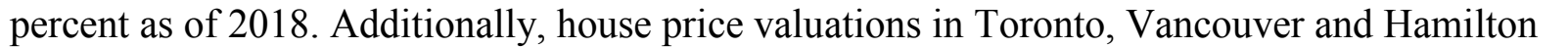

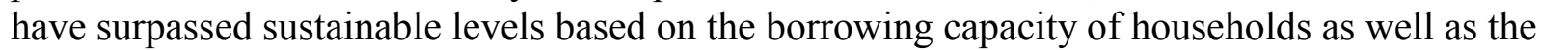

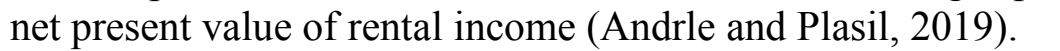

\section{$\square$}

पा ए।

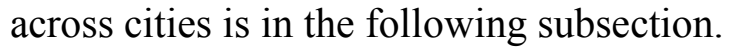


Figure 2. City-Level House Prices-at-risk: The Tails of Two Countries

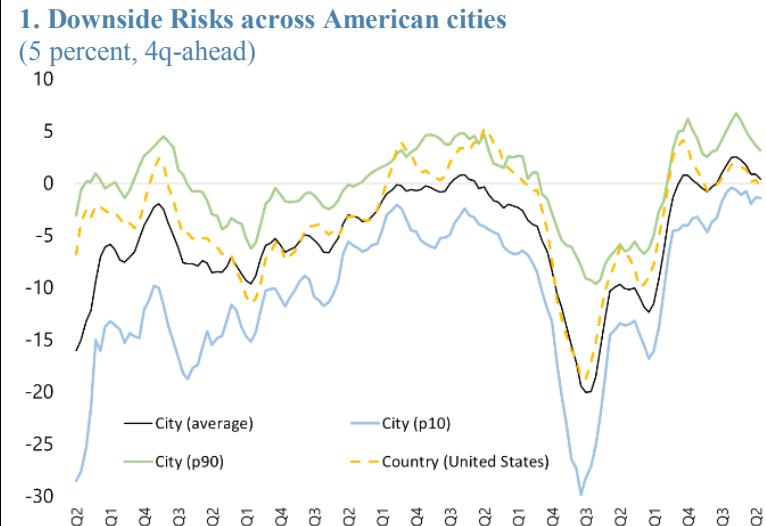

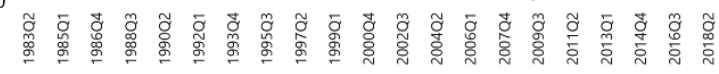

3. Downside Risks and Valuations across American cities

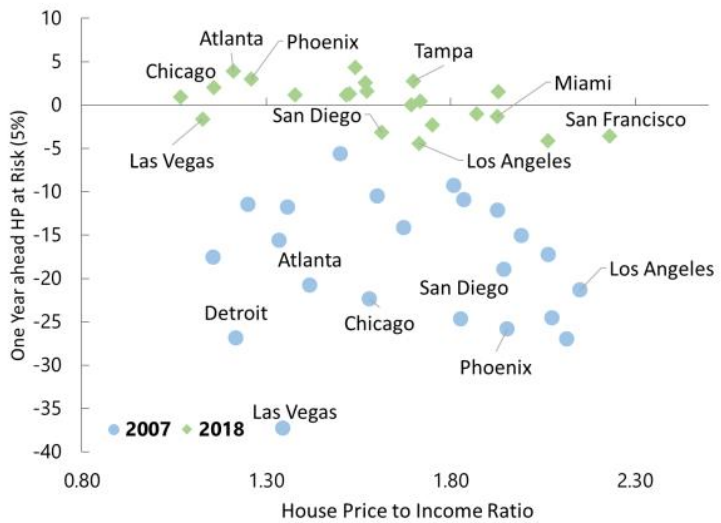

5. Downside Risks across American cities

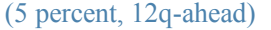

20

10

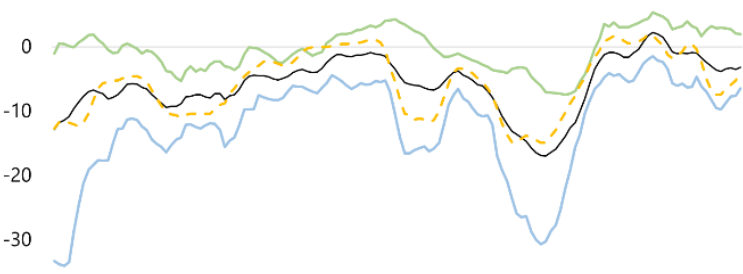

$-40-$ City (average) - City (p10) - City (p90) - - Country (United States)

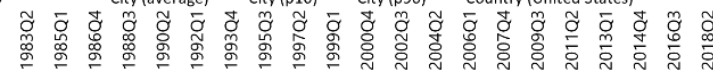

2. Downside Risks across Canadian cities

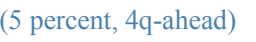

10

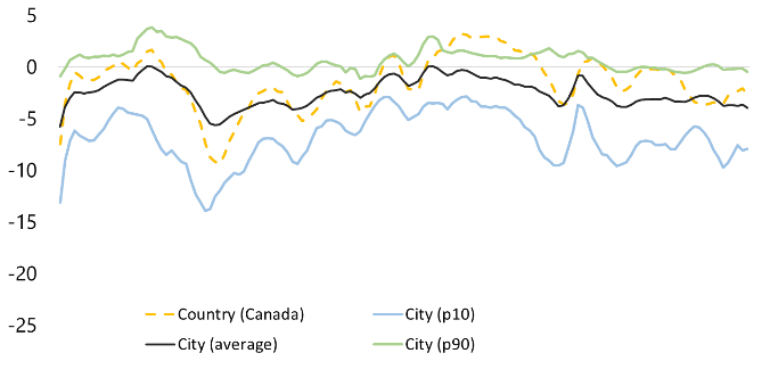

$-30$

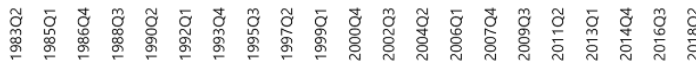

4. Downside Risks and Valuations across Canadian cities

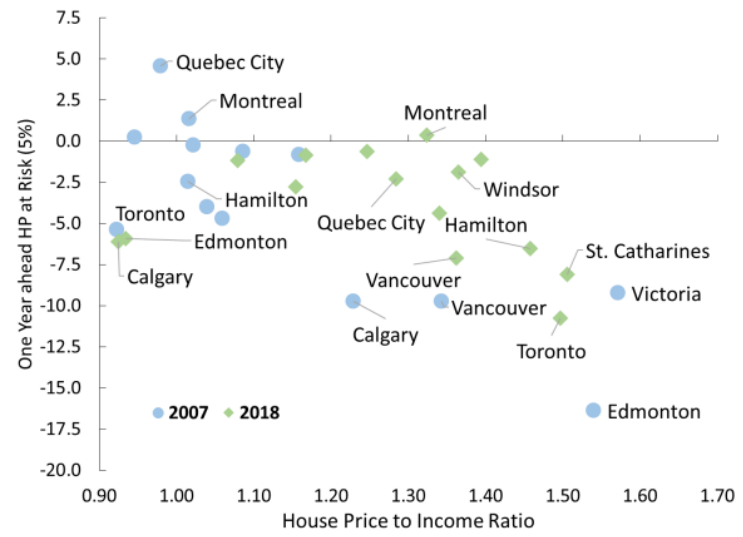

6. Downside Risks across Canadian cities

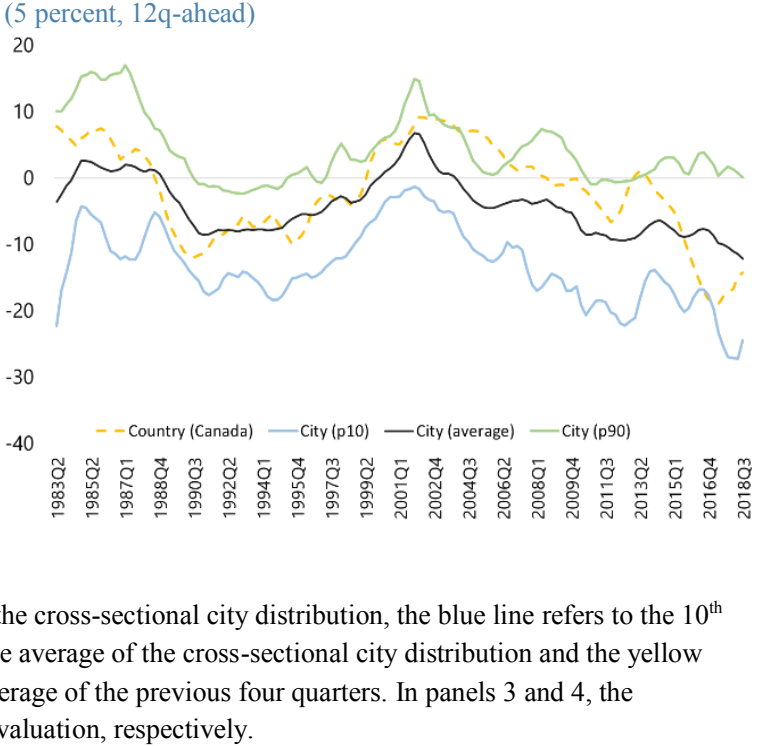




\section{B. Drivers of House Prices-at-Risk}

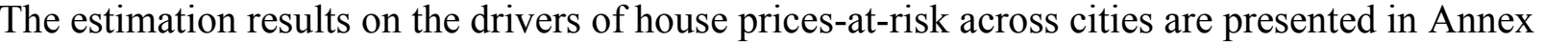

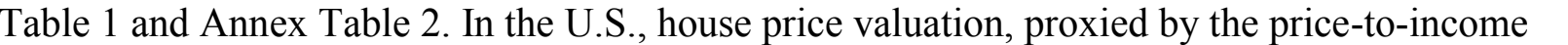

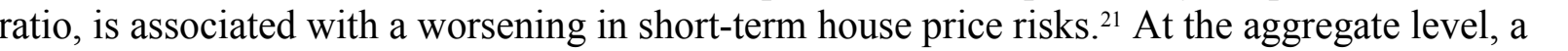

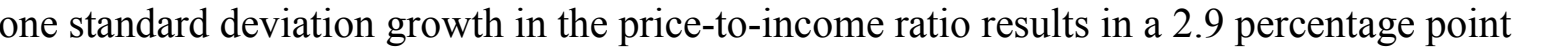

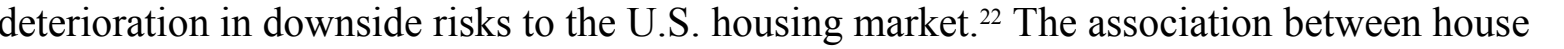

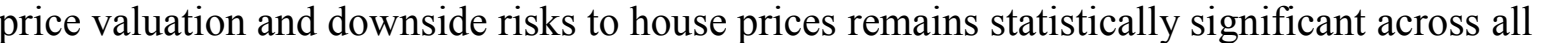

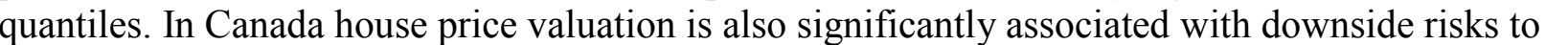

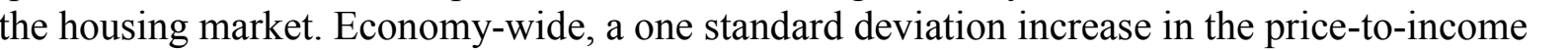

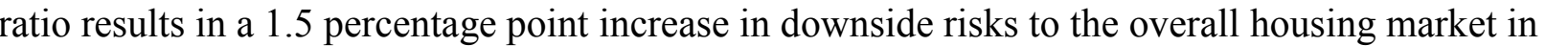

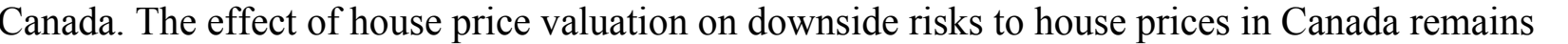

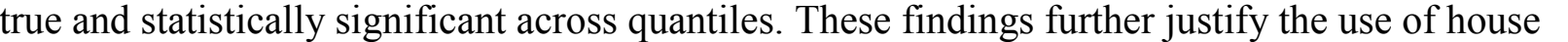

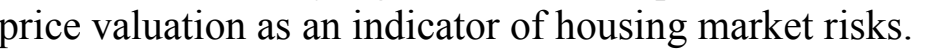

$\square$

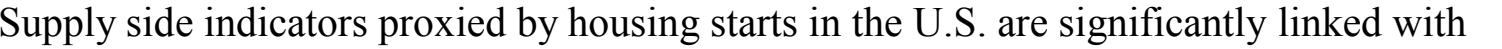

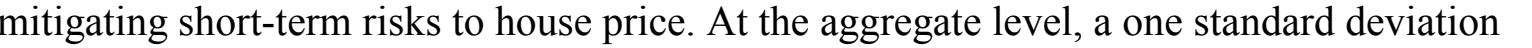

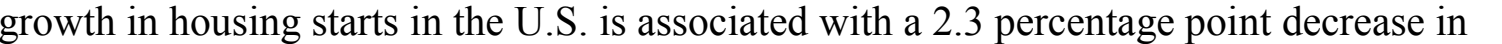

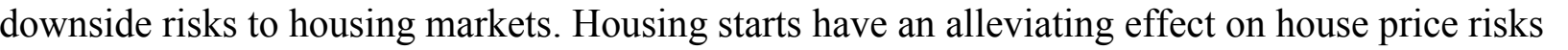

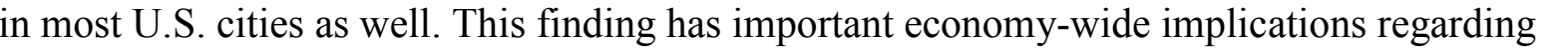

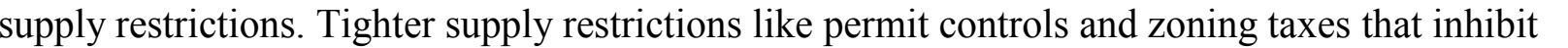

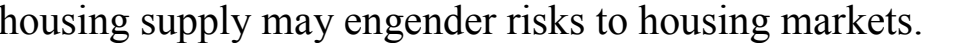

$\square$

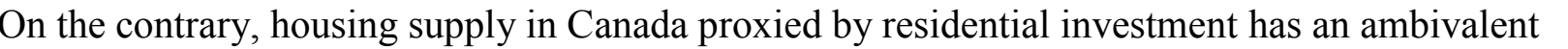

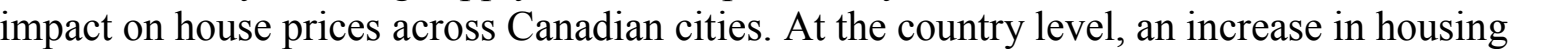

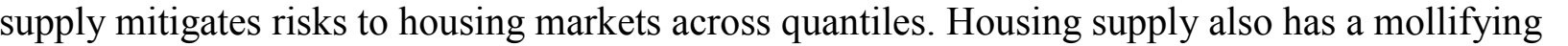

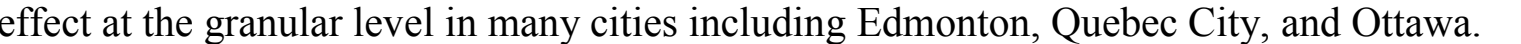

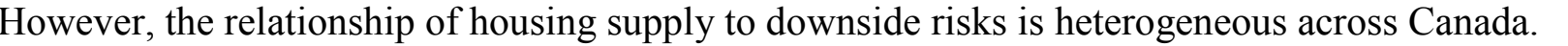

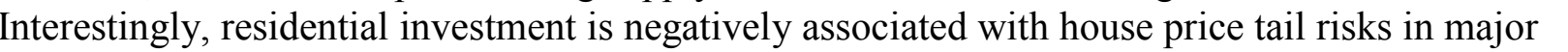

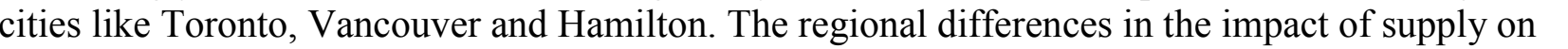

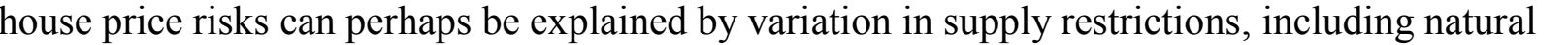

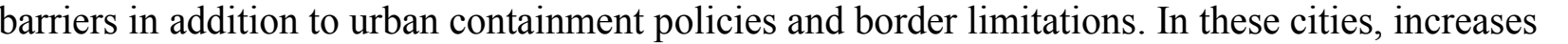
ए

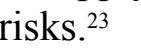

$\square$

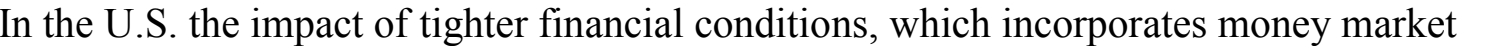

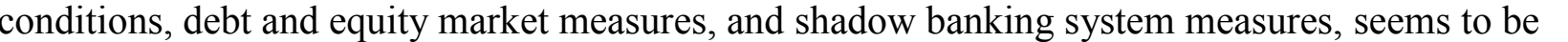

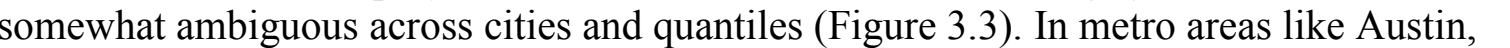

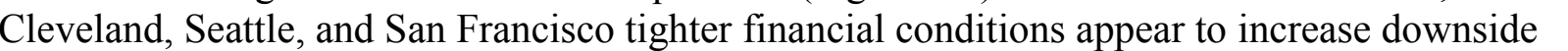

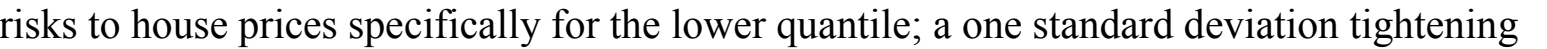

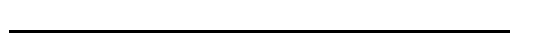

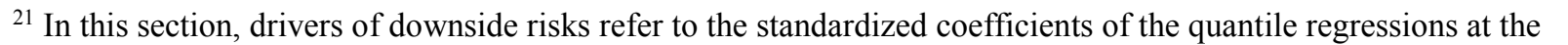

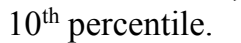

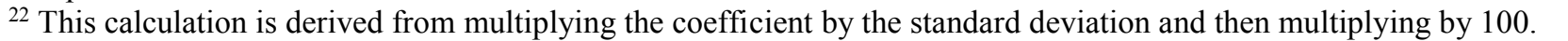

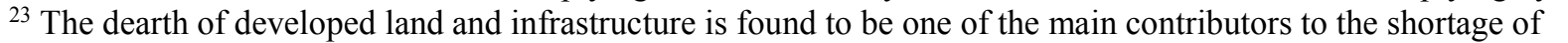

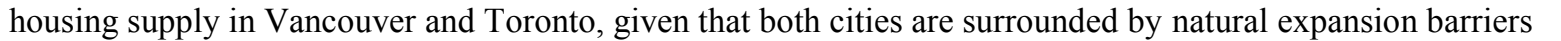
ए

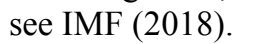




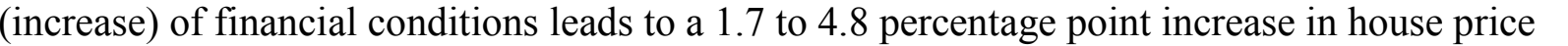

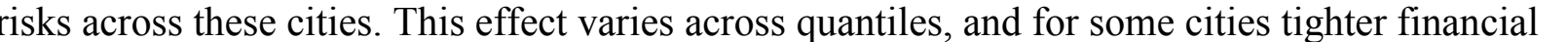

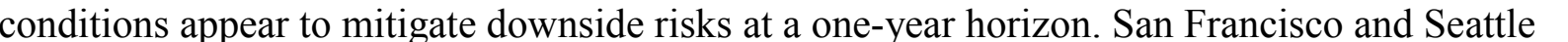

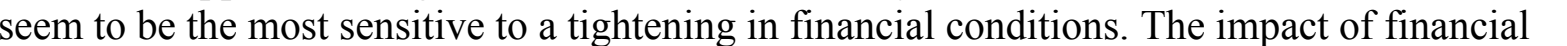

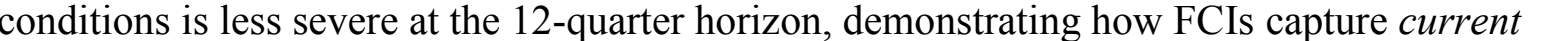

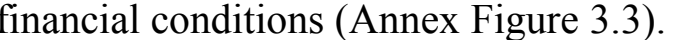

$\square$

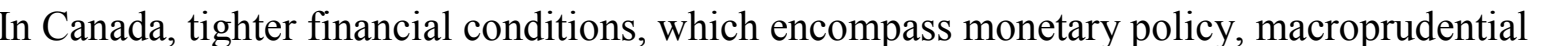

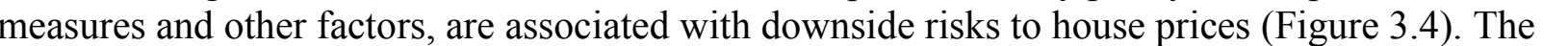

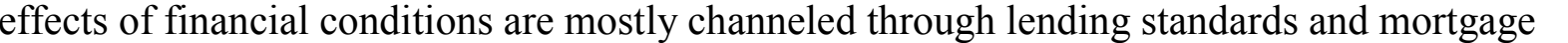

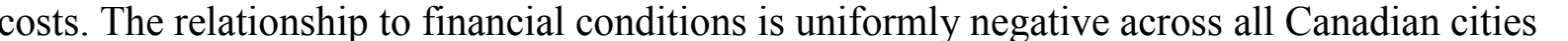

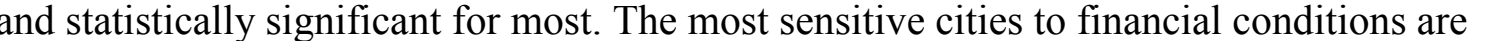

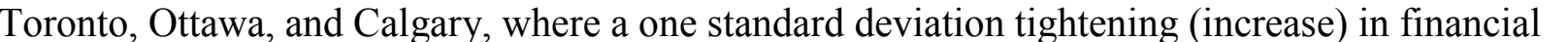

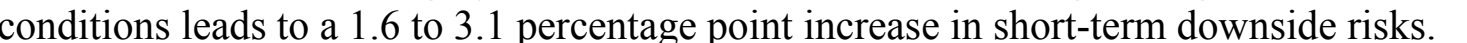

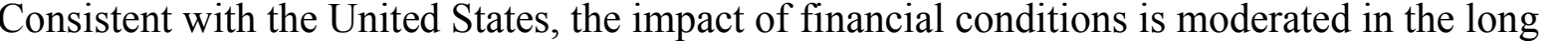

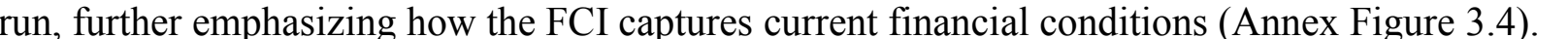
$\square$

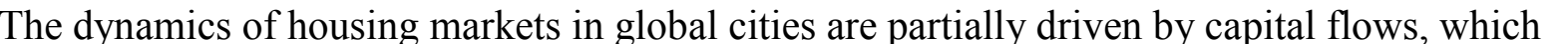

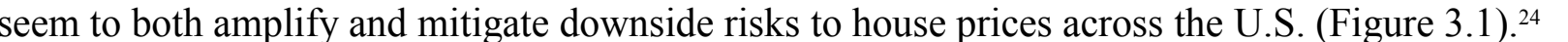

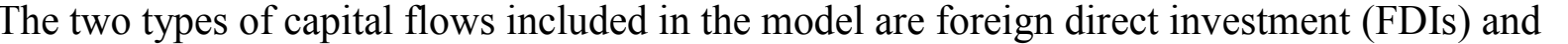

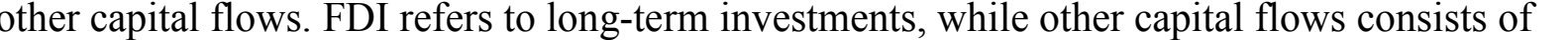

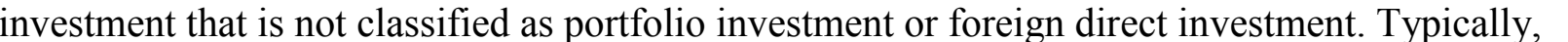

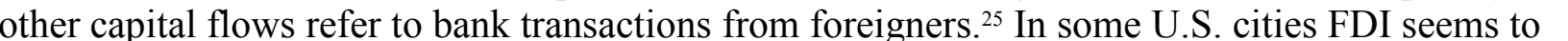

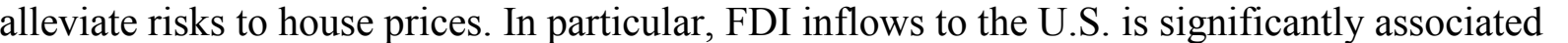

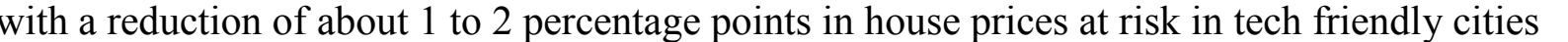

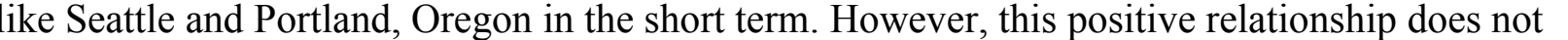

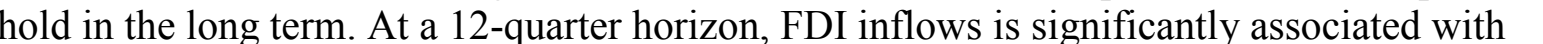

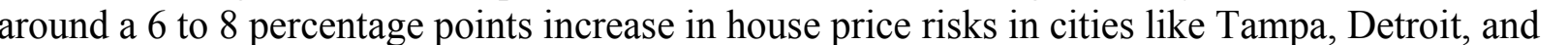

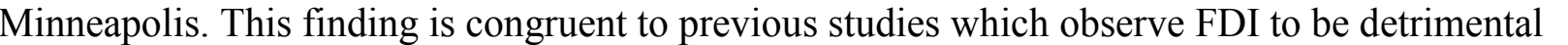

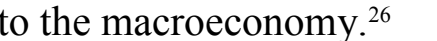

$\square$

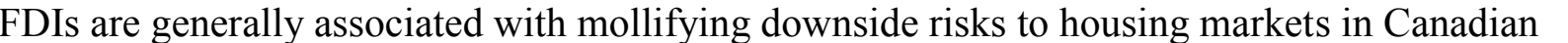

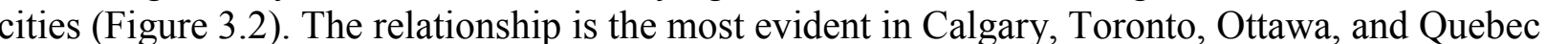

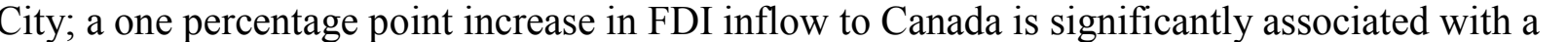

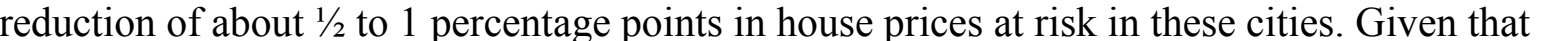

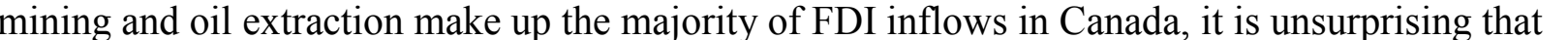

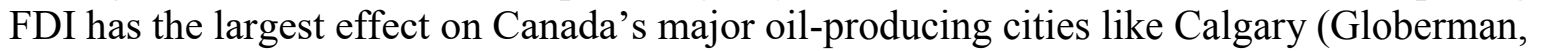

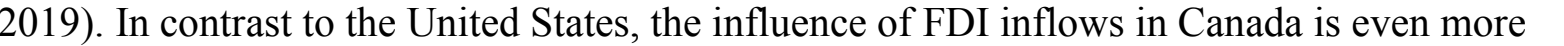

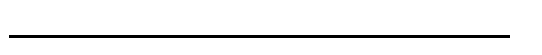

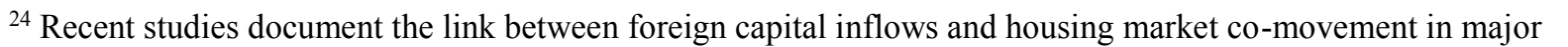

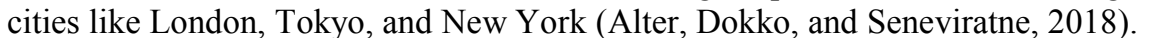

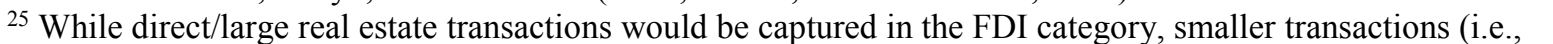
ए एव ए

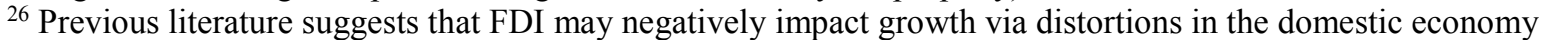

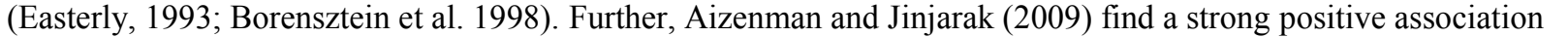

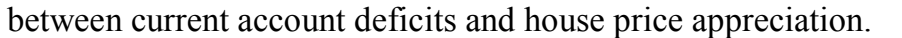




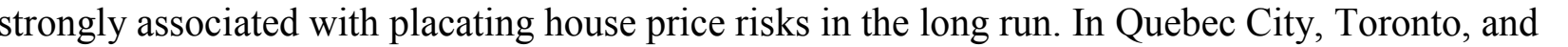

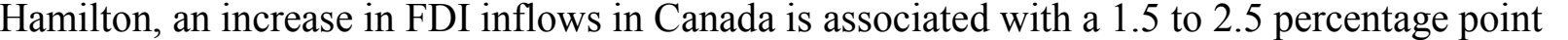

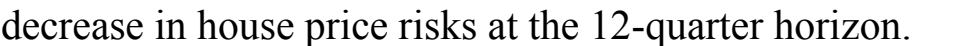

$\square$

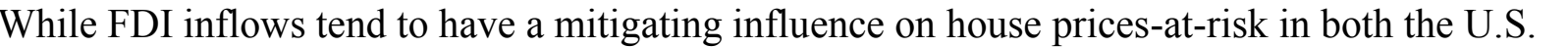

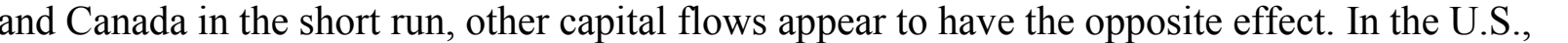

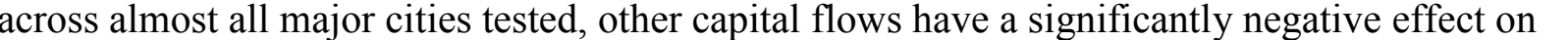

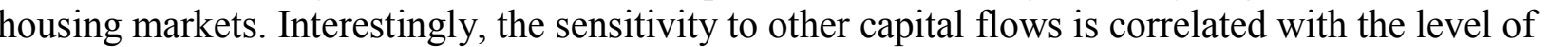

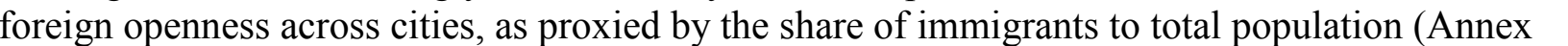

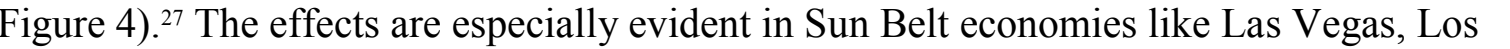

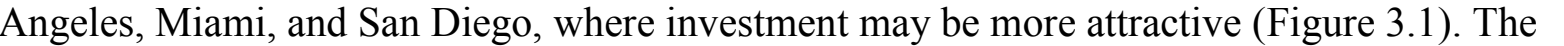

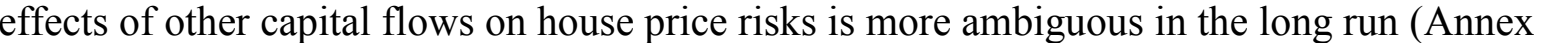

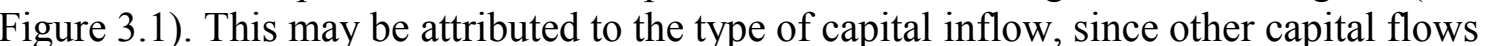
ए

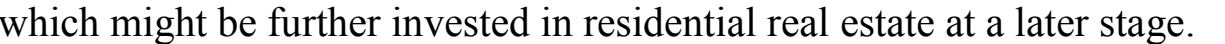

$\square$

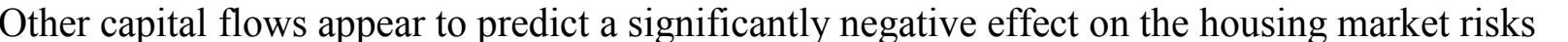

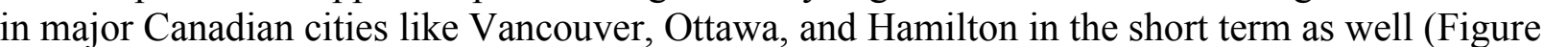

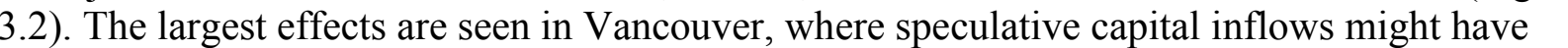

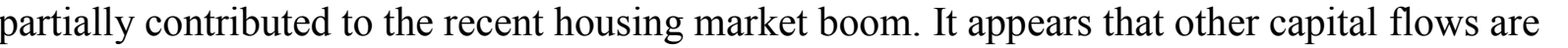
ए।

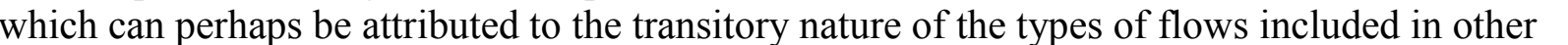

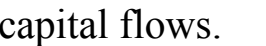

$\square$

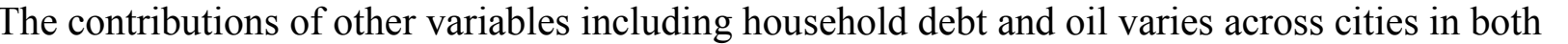

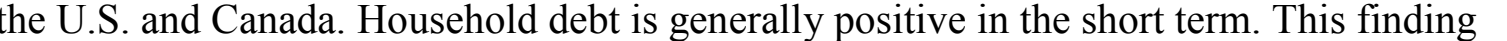

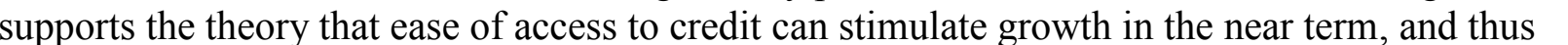

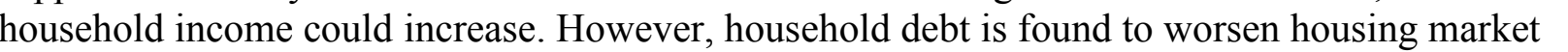

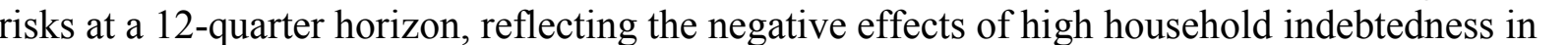

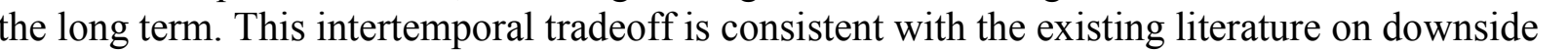

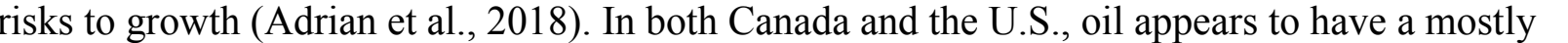

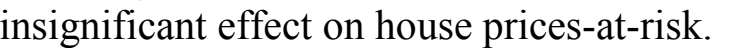

$\square$

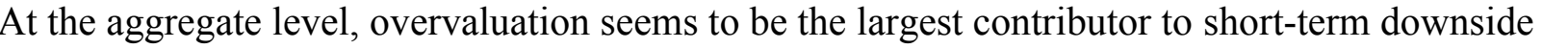

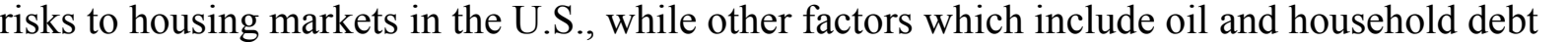

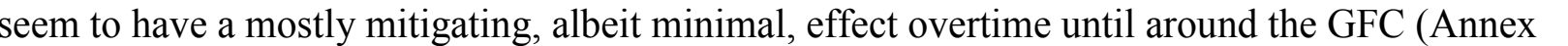

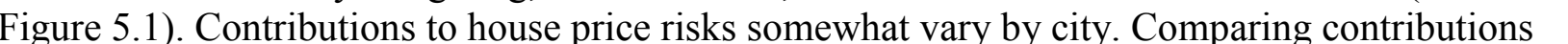

to Los Angeles' house price risks to contributions to Chicago's house price risks exemplifies the

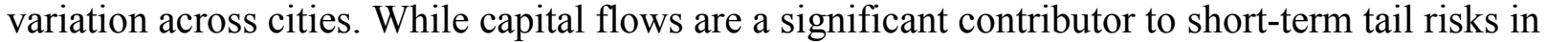

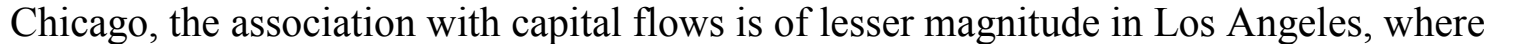

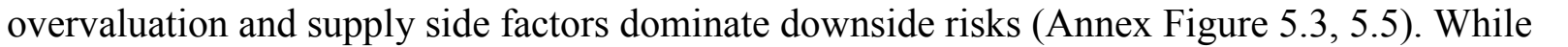

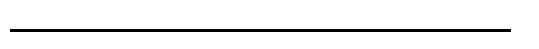

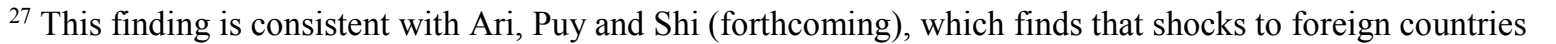

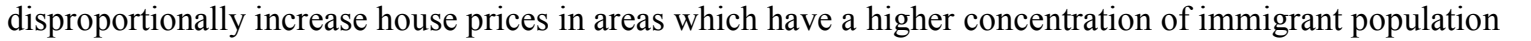

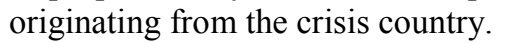




\section{ए}

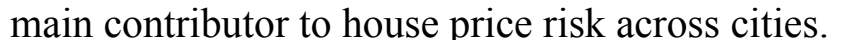

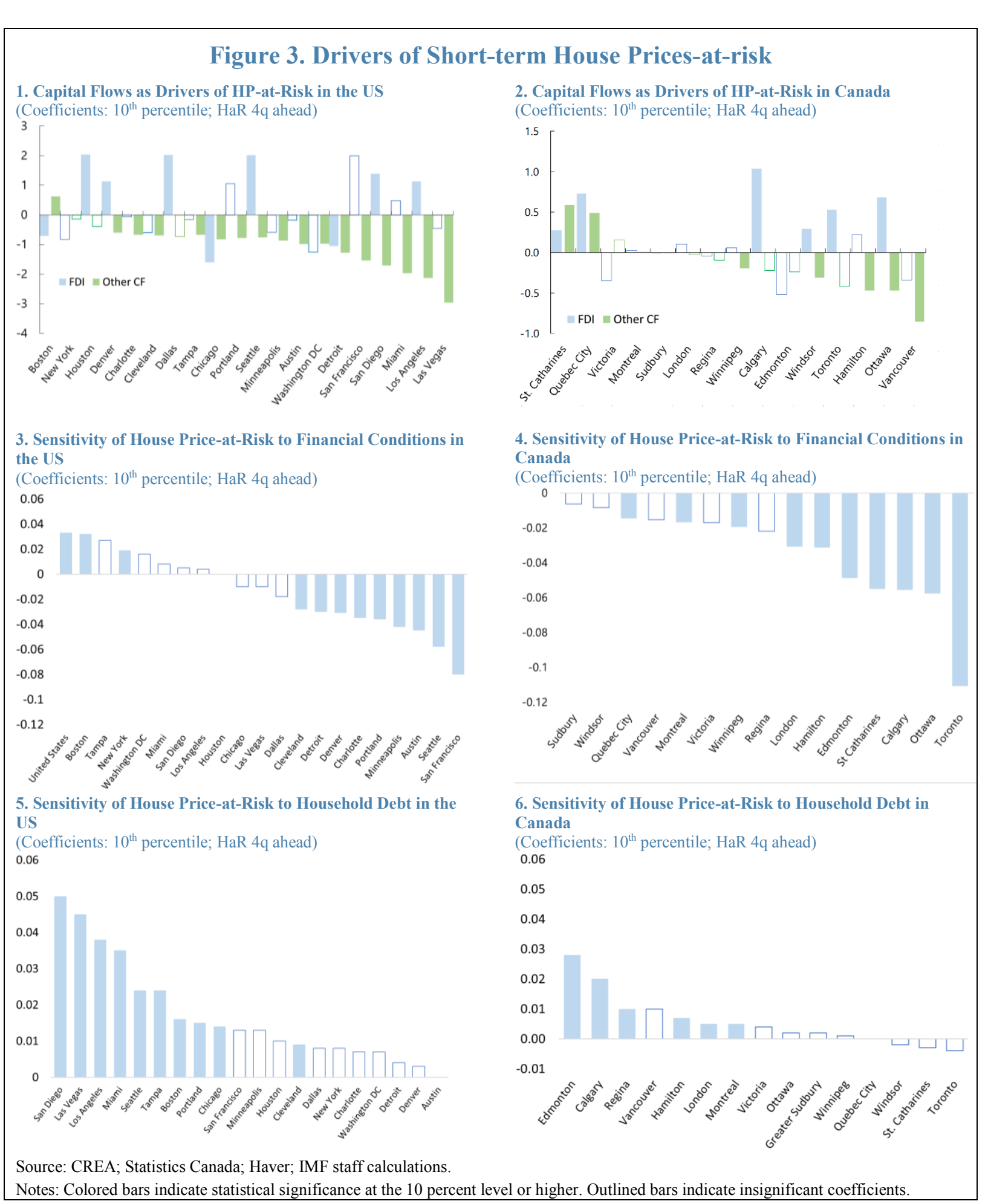

$\square$

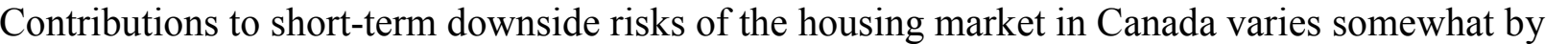

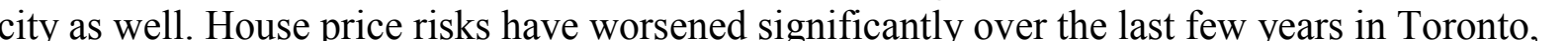


exacerbated by increased overvaluation and constrained supply. Vancouver's housing market

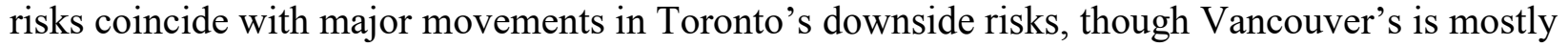

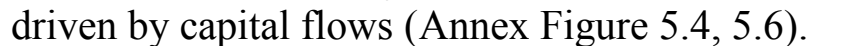

$\square$

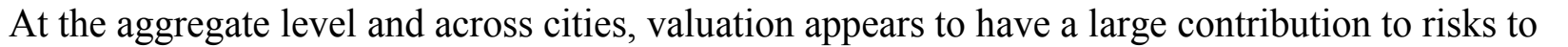

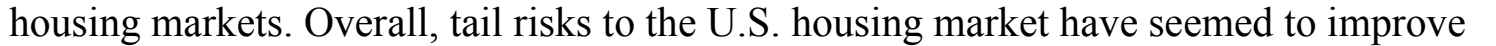

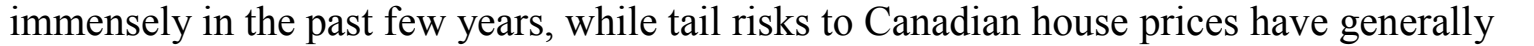

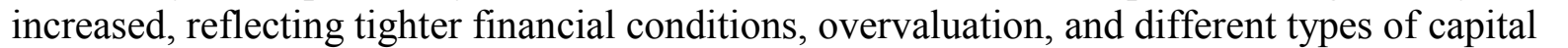
밈밈

$\square$

\section{MicRo-LeVel EVIDENCE: Risky DeBT}

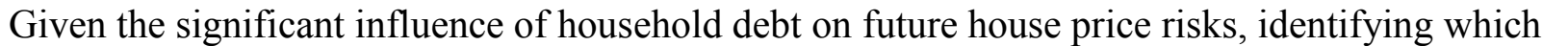
ए

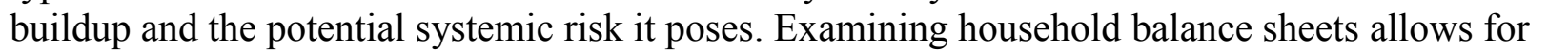

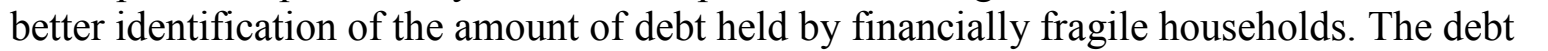

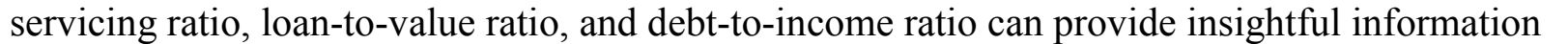

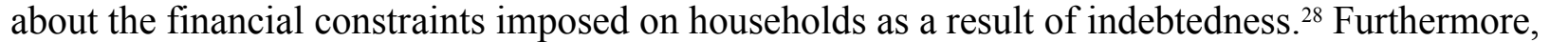

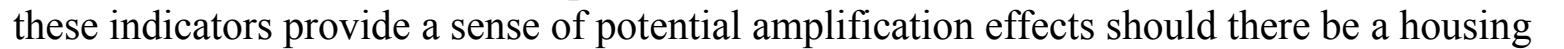

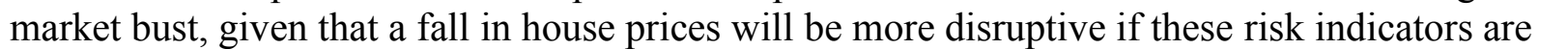

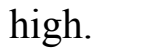

$\square$

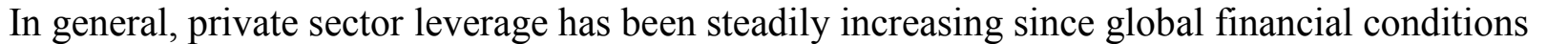

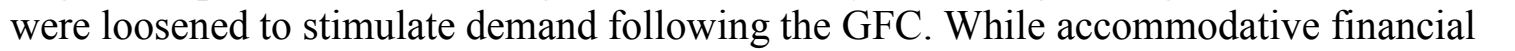

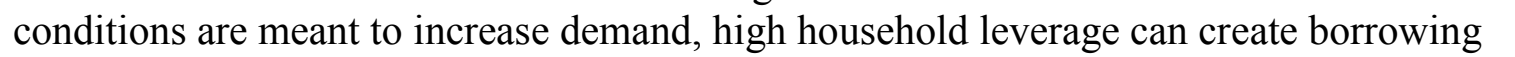

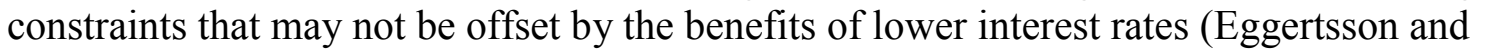

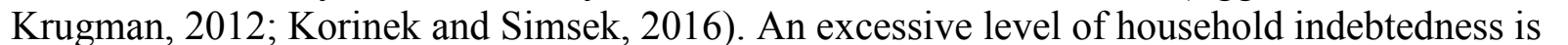

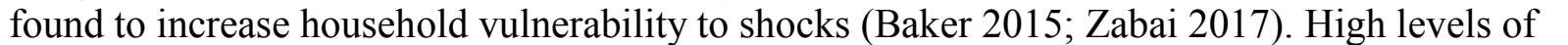

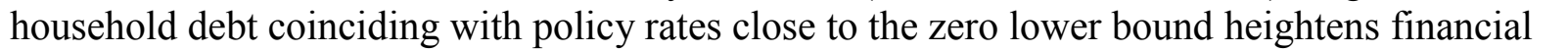

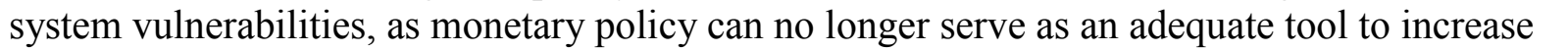

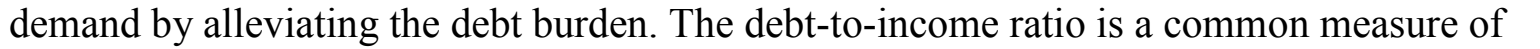

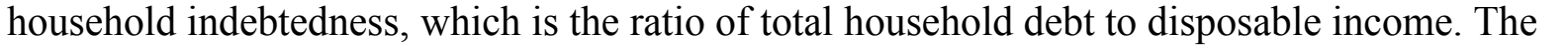

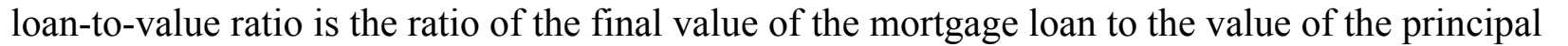

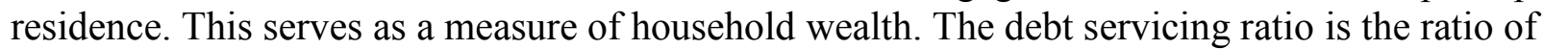

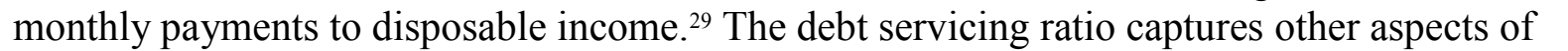

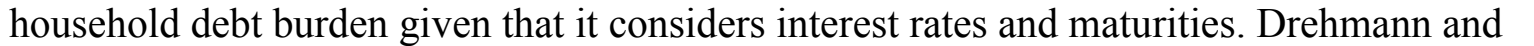

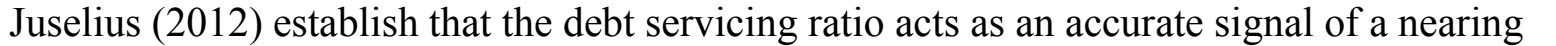

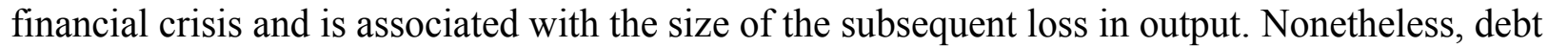

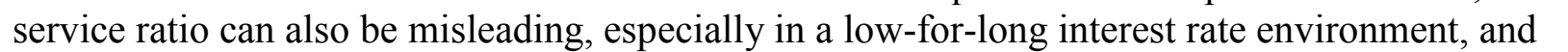

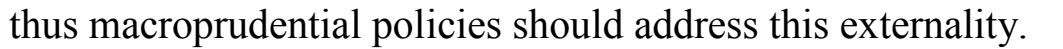

m m+m!m

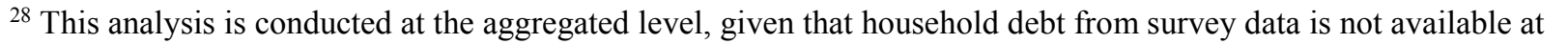

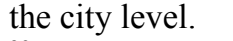

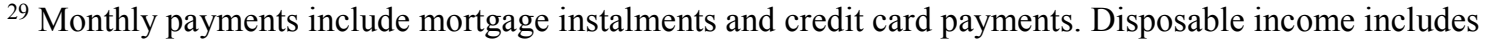

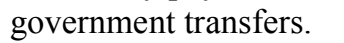




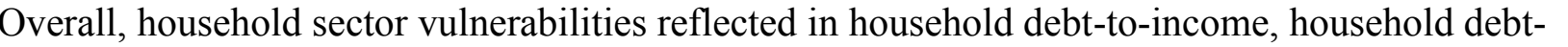

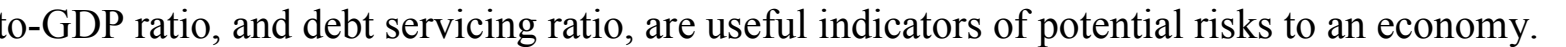

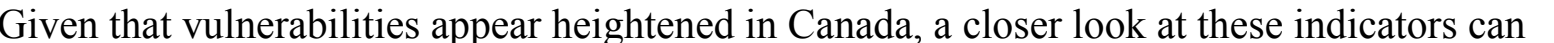

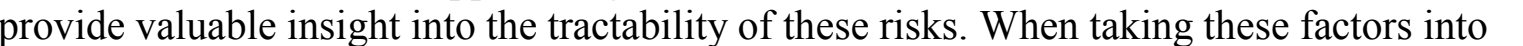

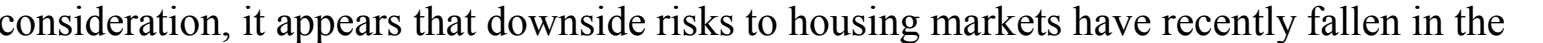

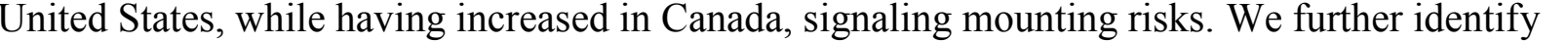

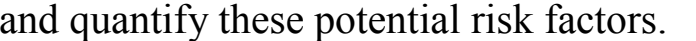

$\square$

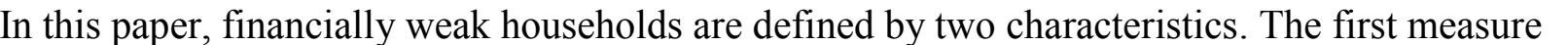

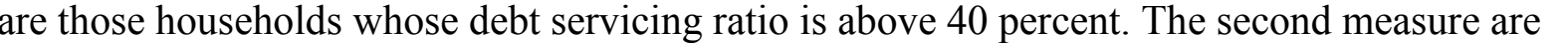

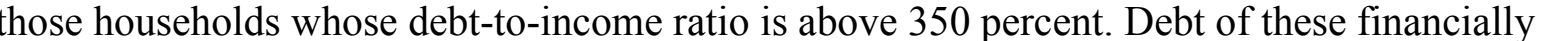
weak households underpins the household “ $\square\|\|\|\| \|$ " concept. Alternative definitions of risky

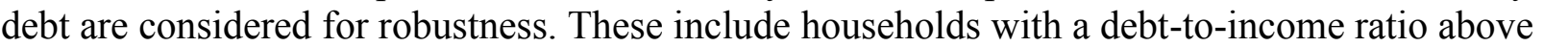

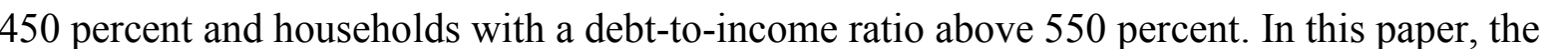

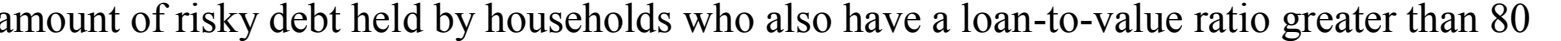

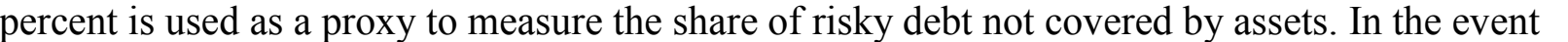

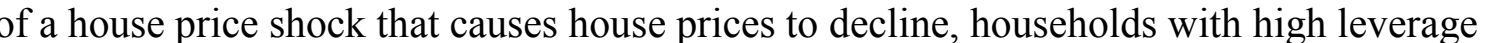

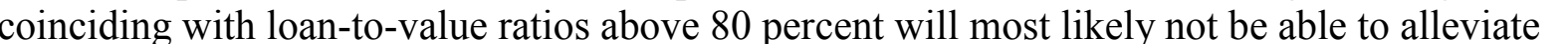

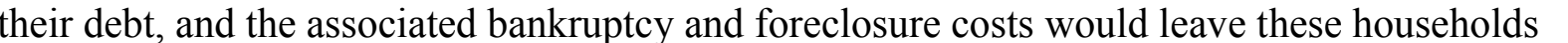

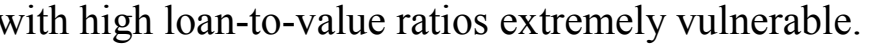

$\square$

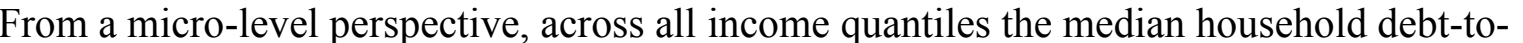
एम

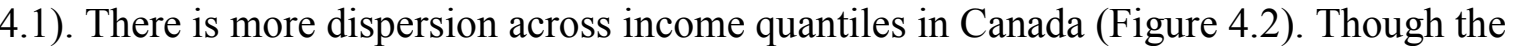

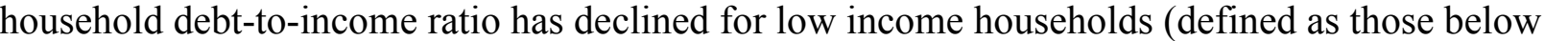
पाm

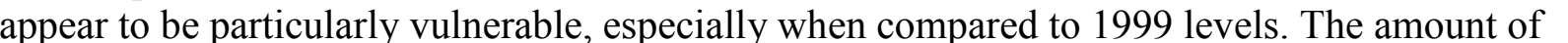

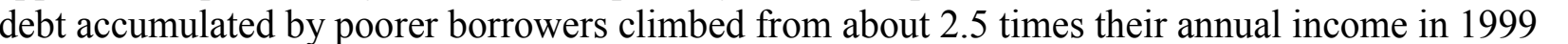

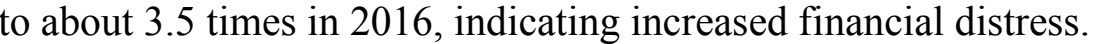

$\square$

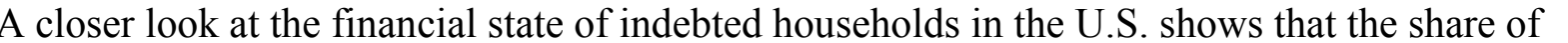

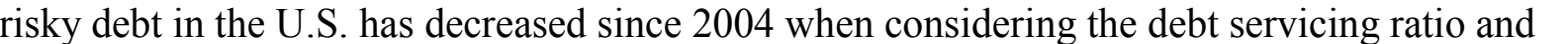

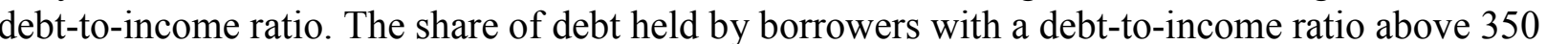

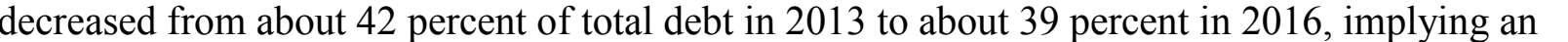

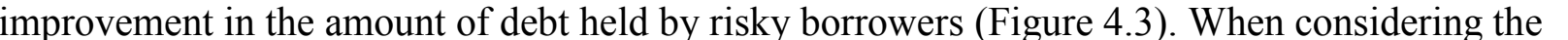

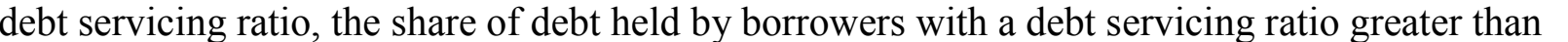

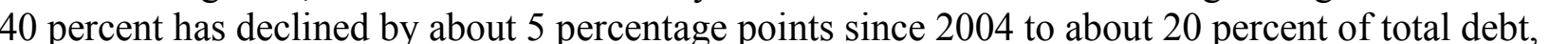

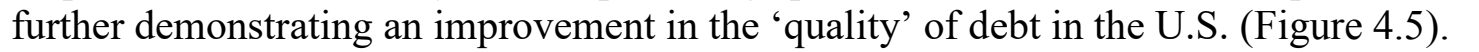

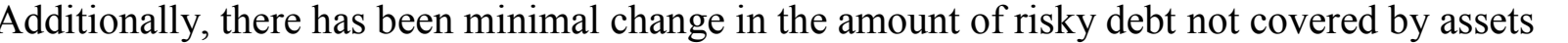
प $\square \square\|\|\|\| \|$

$\square$ 


\section{Figure 4. Household Indebtedness}

1. Debt-to-Income (DTI) in the US

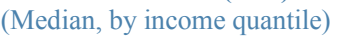

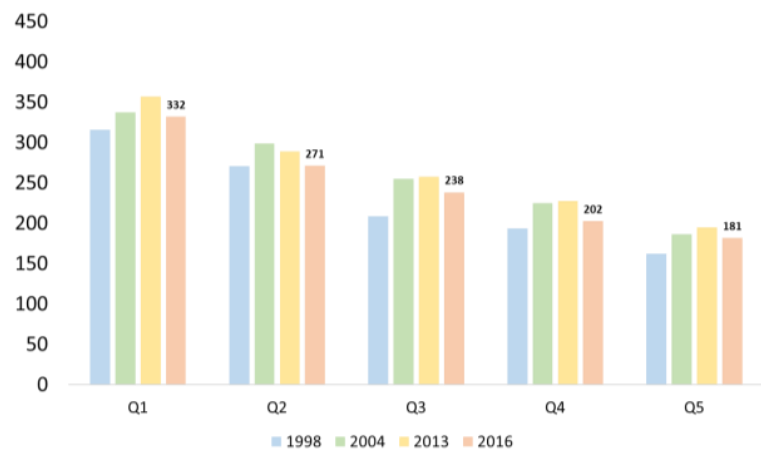

3. Household Risky Debt in the US, 1998-2016

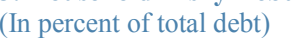

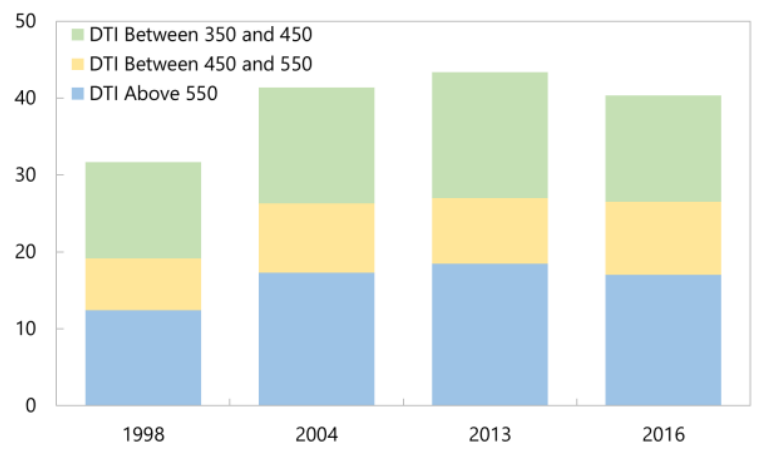

5. Share of Risky Debt in the US, 2016

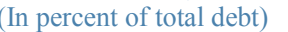

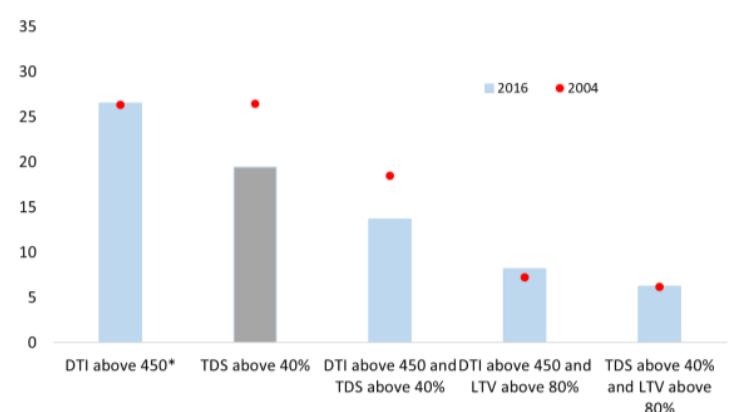

2. Debt-to-Income (DTI) in Canada

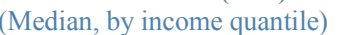

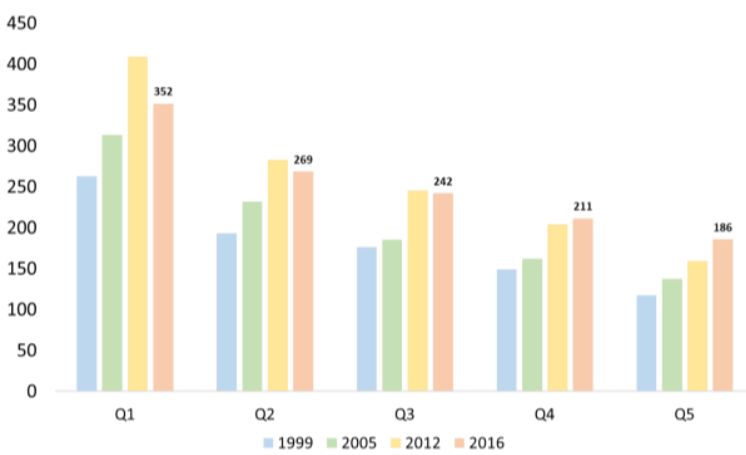

4. Household Risky Debt in Canada, 1999-2016

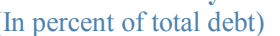

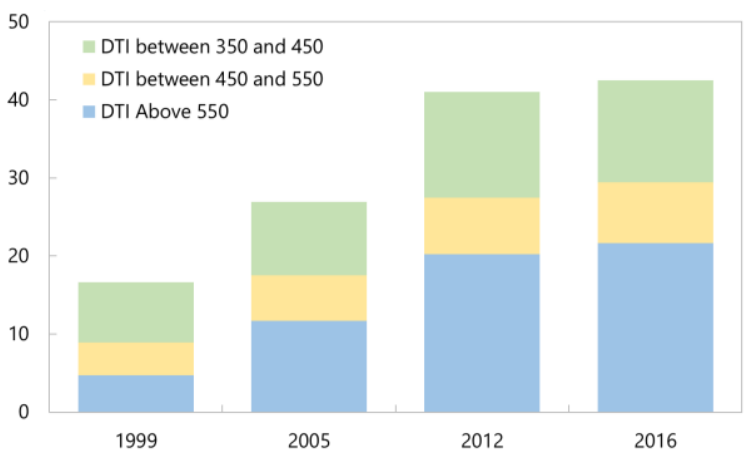

6. Share of Risky Debt in Canada, 2016

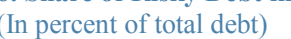

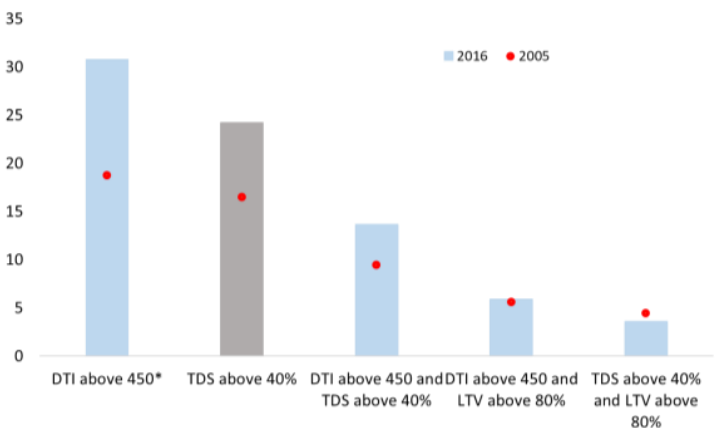

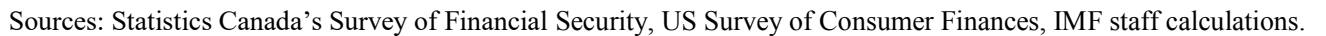

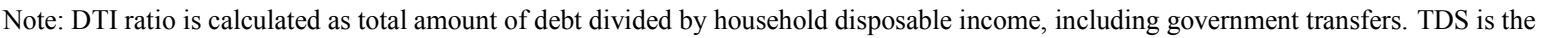

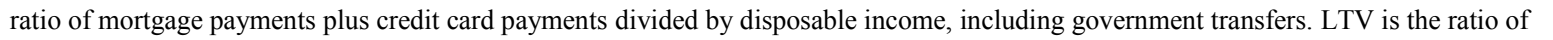

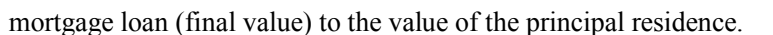




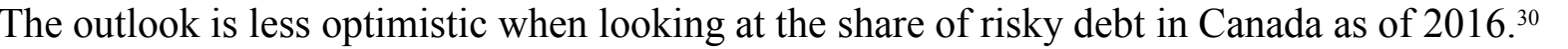

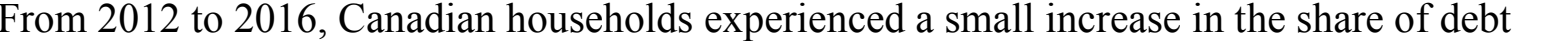

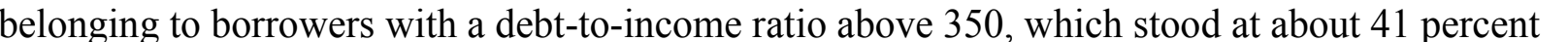

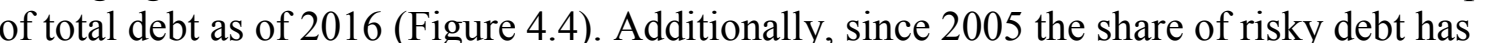

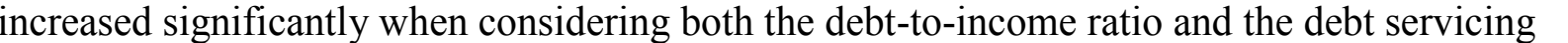

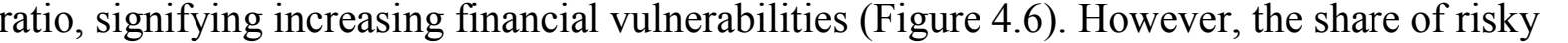

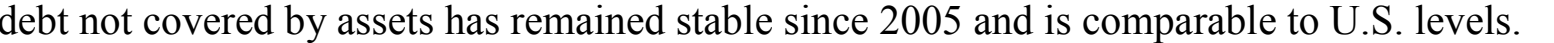
$\square$

\section{RoBUSTNESS}

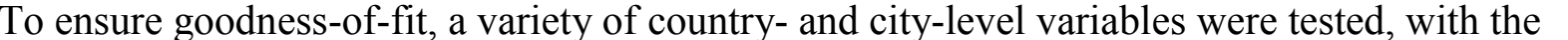

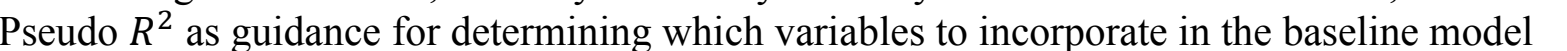

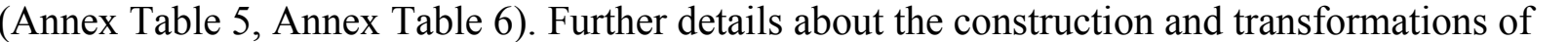

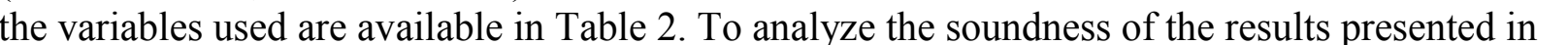

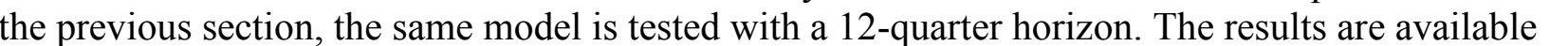

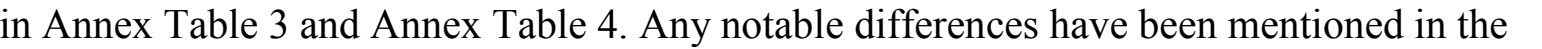

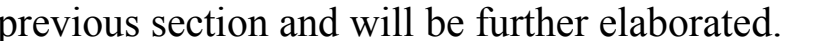

$\square$

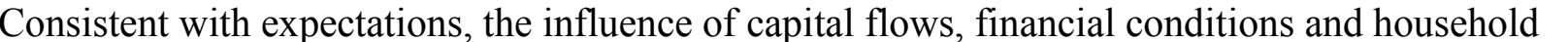

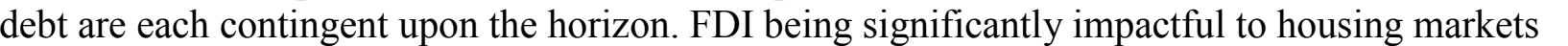

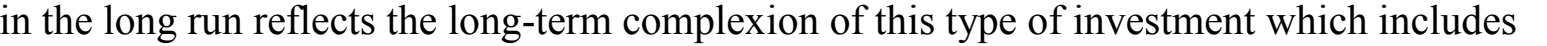

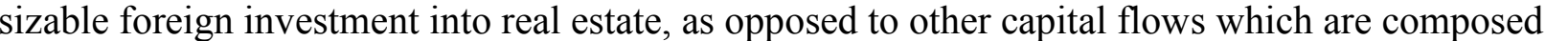

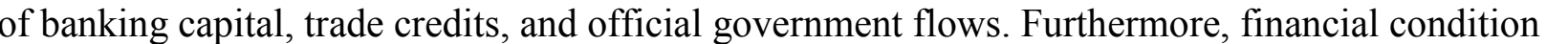
ए

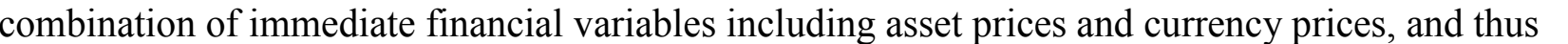
प ए

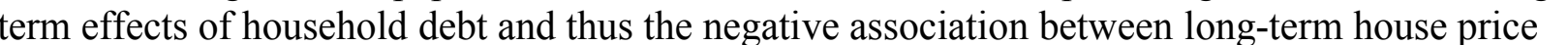

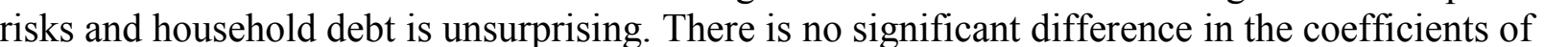

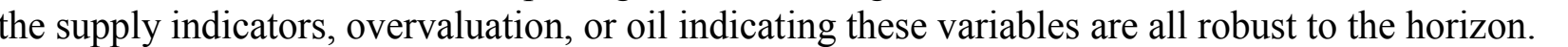

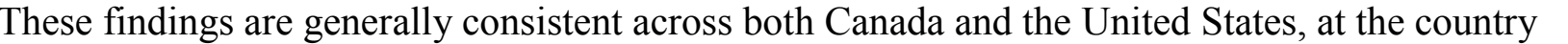

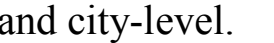

$\square$

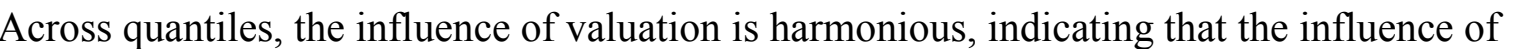

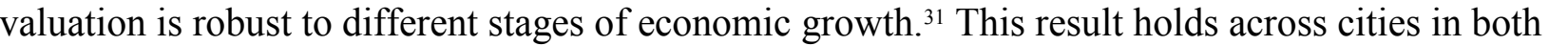

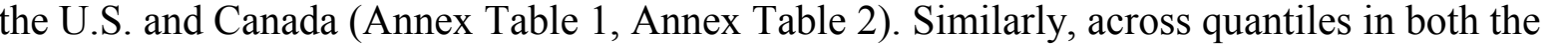

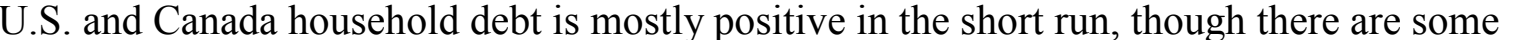

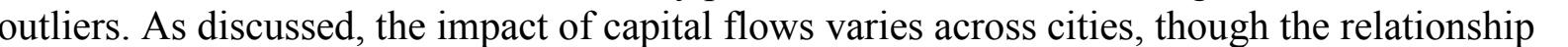

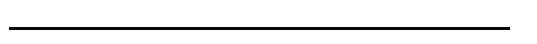

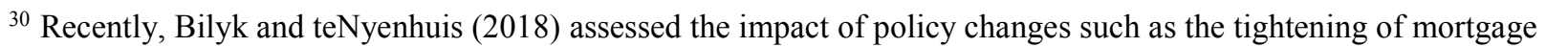

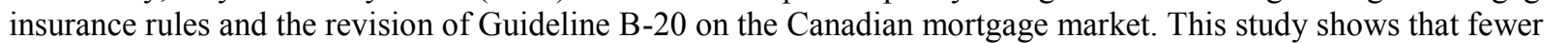

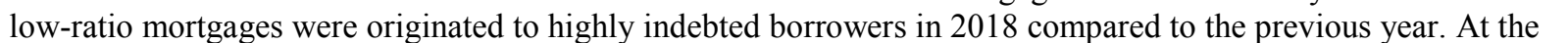

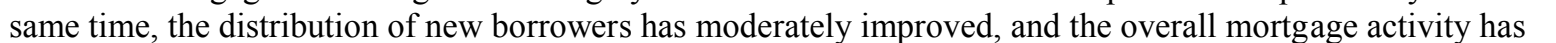

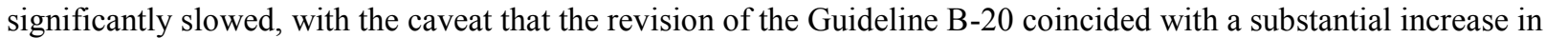

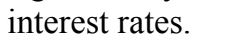

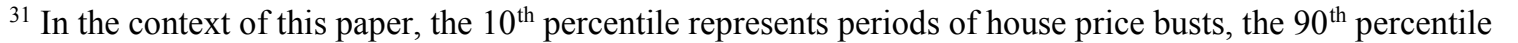

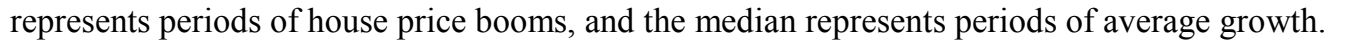




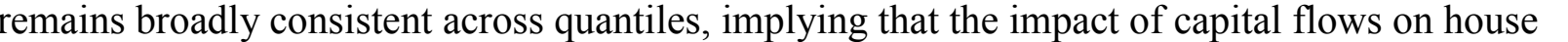

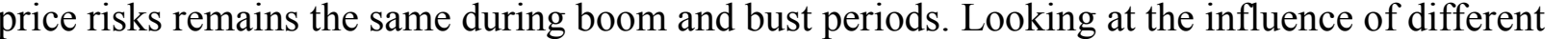

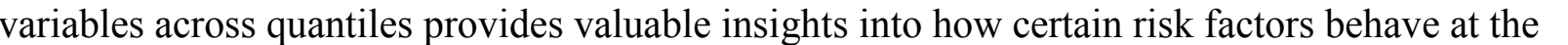

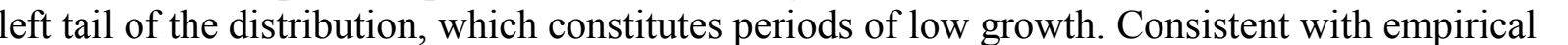

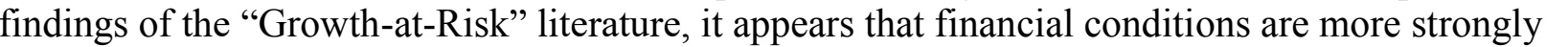

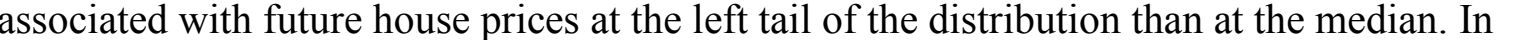

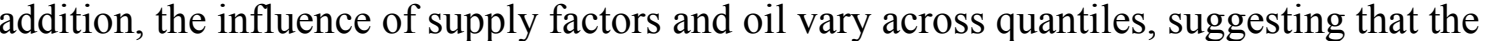

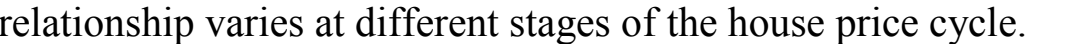

$\square$

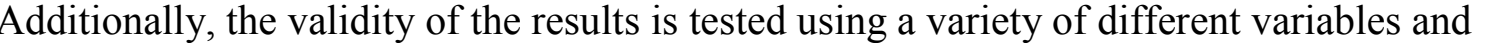

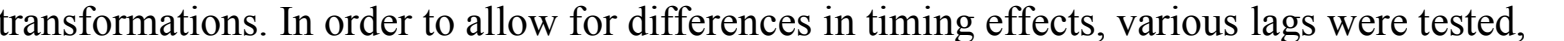
ए

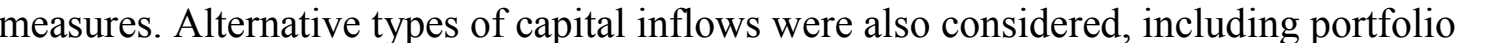

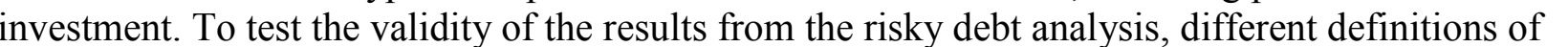

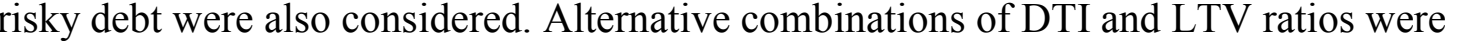

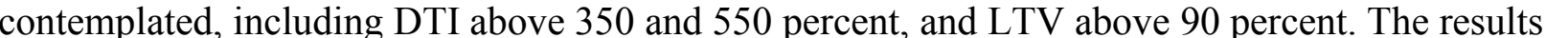

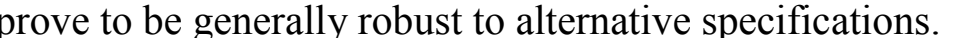




\section{CONCLUSION}

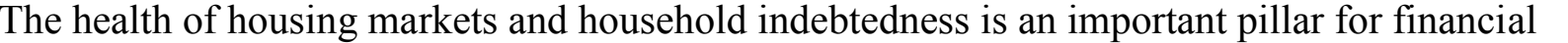

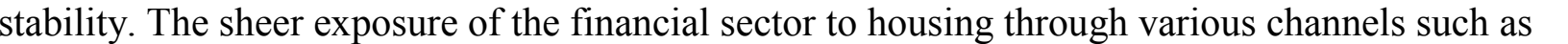

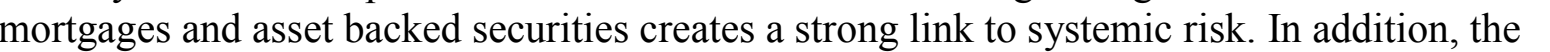

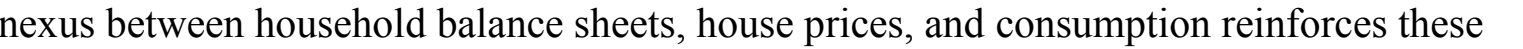
$\square \square\|1\| \square \square \square$

$\square$

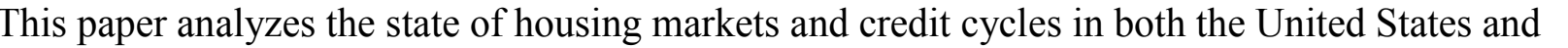

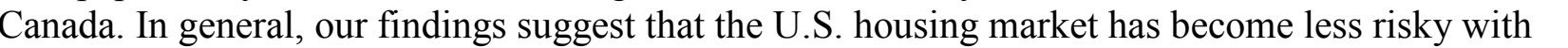

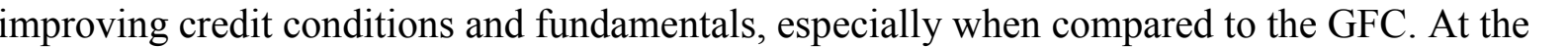

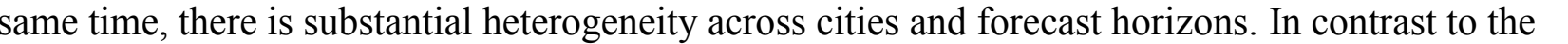

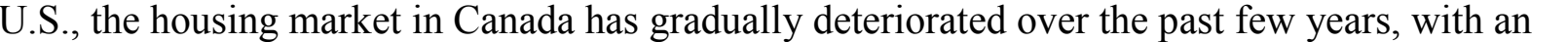
पा

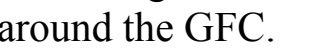

$\square$

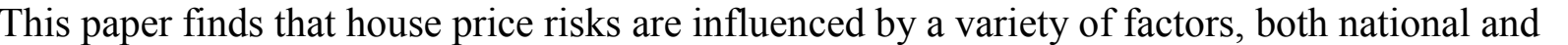
ए

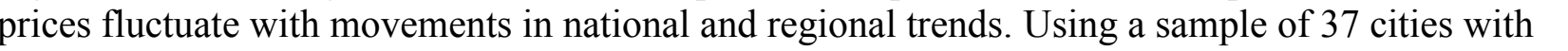

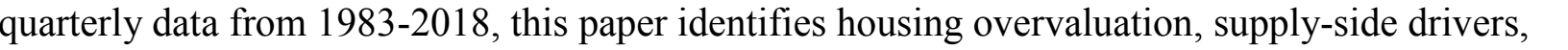

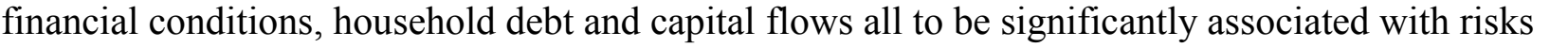

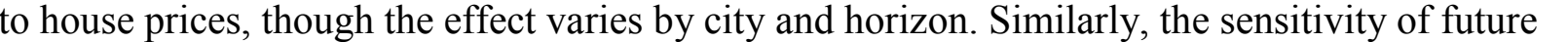

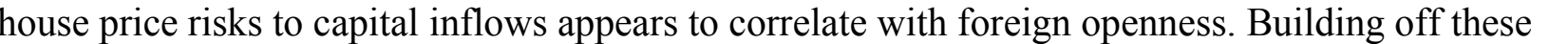
ए पा

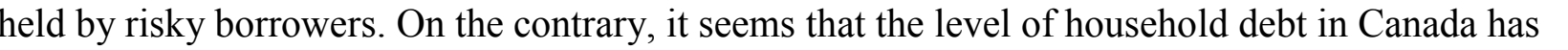

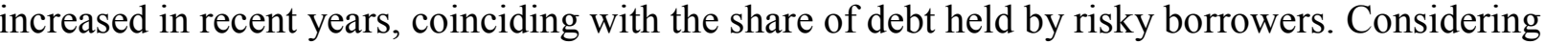

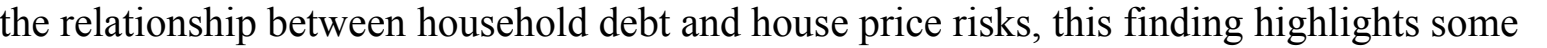

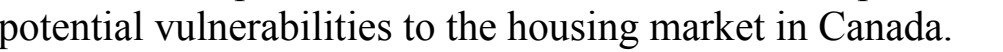

$\square$

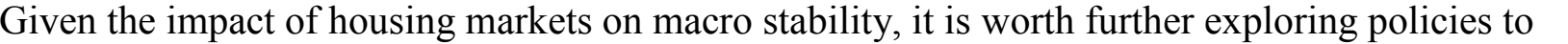

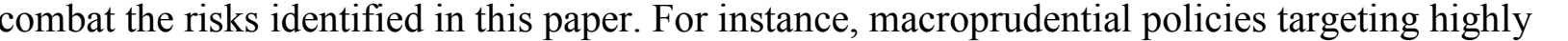

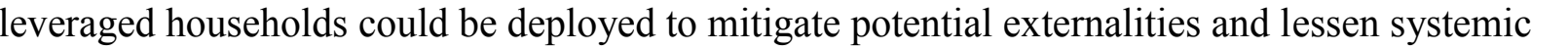
प

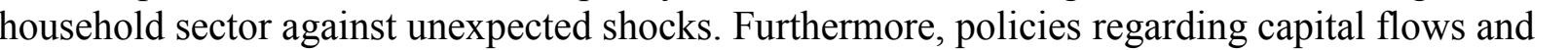

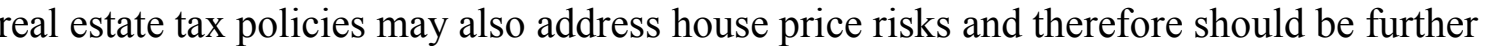

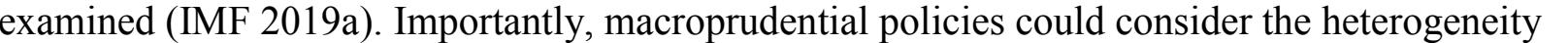

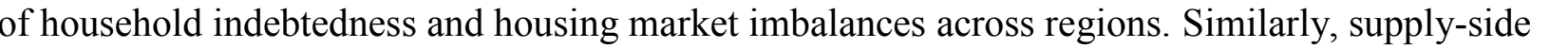

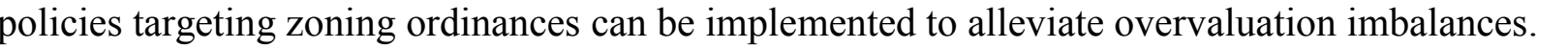

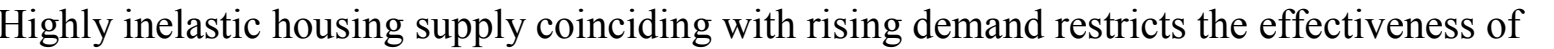

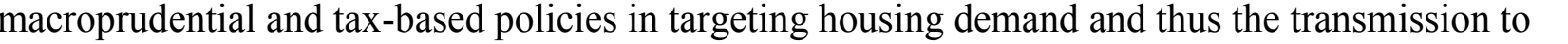

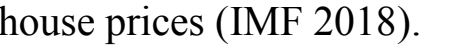


Table 1. City List

\begin{tabular}{|c|c|c|c|}
\hline \multicolumn{2}{|c|}{ United States } & \multicolumn{2}{|c|}{ Canada } \\
\hline$\square \square \square \|$ & $\square \square \square$ & 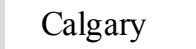 & 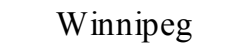 \\
\hline 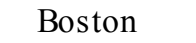 & 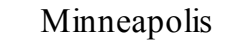 & 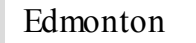 & 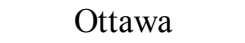 \\
\hline 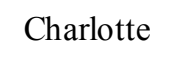 & 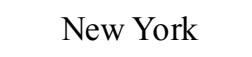 & पमएण & 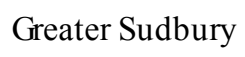 \\
\hline पणमाए & 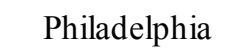 & 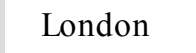 & 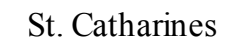 \\
\hline पणामाप & $\square \square \square \square \square$ & 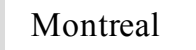 & \\
\hline प्णाए & 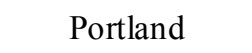 & 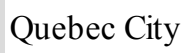 & \\
\hline$\square \square \square \square \square$ & पणापणए & पणाएण & \\
\hline 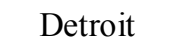 & 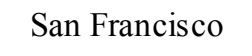 & 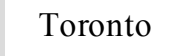 & \\
\hline$\square \square \square \square \square$ & 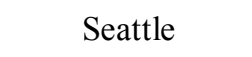 & 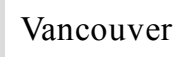 & \\
\hline 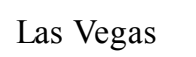 & $\square \square \square \square$ & पणाणा & \\
\hline 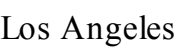 & 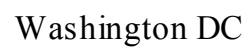 & $\square \square \square \square \square$ & \\
\hline
\end{tabular}

\section{Table 2. Variable Descriptions}

\begin{tabular}{|c|c|c|c|c|c|}
\hline \multicolumn{3}{|c|}{ United States } & \multicolumn{3}{|c|}{ Canada } \\
\hline 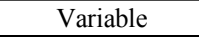 & 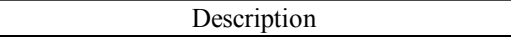 & $\square 110$ & पपाणापा & 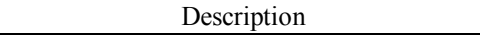 & $\square \mid \Pi \square$ \\
\hline 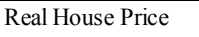 & 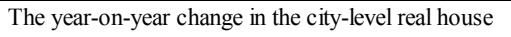 & 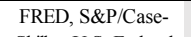 & पषापापाषा & 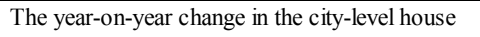 & \\
\hline पण口ण & 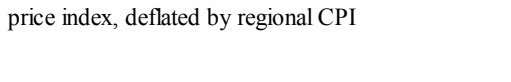 & 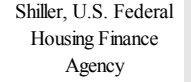 & 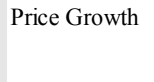 & 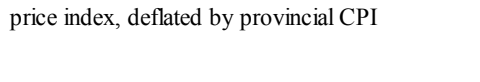 & 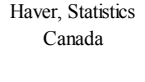 \\
\hline 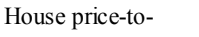 & 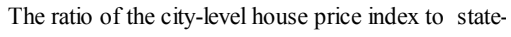 & & पणापाएण & 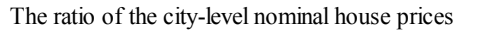 & \\
\hline पाएव & 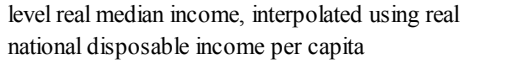 & 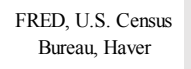 & पणाएव & 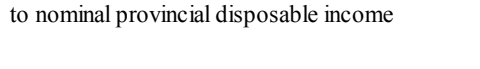 & 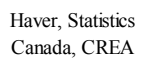 \\
\hline 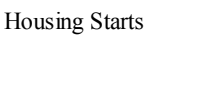 & 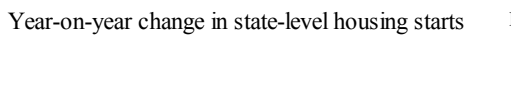 & 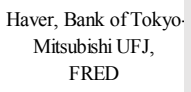 & 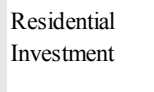 & 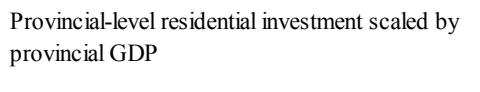 & 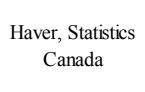 \\
\hline 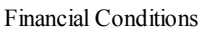 & 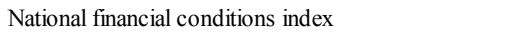 & & 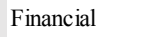 & 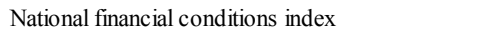 & \\
\hline पाषाणापा & & 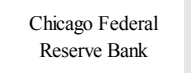 & 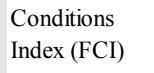 & & 四문 \\
\hline पणाणापापा & 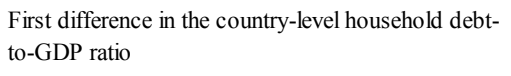 & मपाणापा & $\begin{array}{l}\square \square \Pi \| \square \square \\
\square \square \square\end{array}$ & 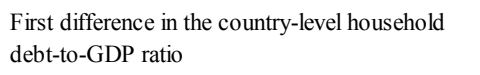 & पणाणाप \\
\hline 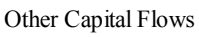 & 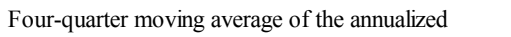 & & 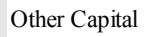 & 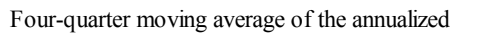 & \\
\hline & 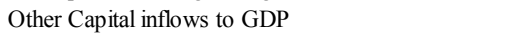 & 四四四 & प्राप्र & 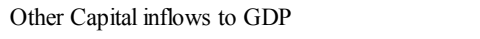 & 四 \\
\hline पणमाणाएा & 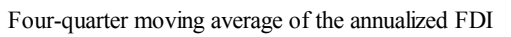 & & 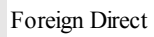 & 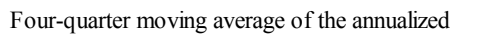 & \\
\hline 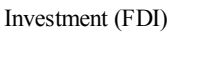 & 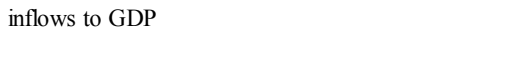 & 四 प⿴囗十丁口卄 & 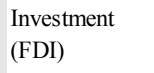 & 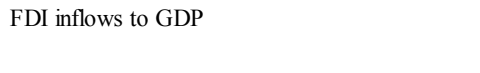 & 四 \\
\hline$\square \square$ & 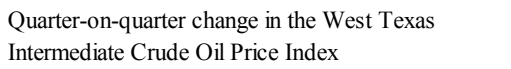 & $\square \square \square$ & $\square \square$ & 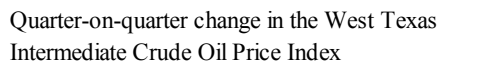 & $\square \square$ \\
\hline
\end{tabular}


Table 3. Country-level Summary Statistics

United Sates

\begin{tabular}{|c|c|c|c|c|c|}
\hline Variable & 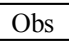 & $\square \square$ & 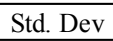 & $\square \mathbb{\square}$ & $\square \square$ \\
\hline House Price Growth (YoY) & $\square$ & 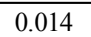 & 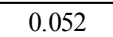 & पाणा & पाII \\
\hline House Price-to-Income & $\square$ & पणा & एणा & एणाए & पा। \\
\hline Housing Starts (YoY) & $\square$ & $\square \square$ & पणाप & एणा & पणा \\
\hline FCI & $\Pi$ & घाए & पणा & एखा & पणा \\
\hline$\Delta$ Household Debt (\% of GDP) & $\square$ & एणा & पाए & एणा & पाए \\
\hline FDI (\% of GDP) & $\square$ & पणाए & पणाए & $\square \square$ & पणा \\
\hline Other Capital Flows (\% of GDP) & 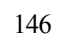 & पणाप & पणाए & पाण & एणा \\
\hline Oil (QoQ) & $\Pi$ & पाणा & पाण & एणाए & पणा \\
\hline
\end{tabular}

Canada

\begin{tabular}{|c|c|c|c|c|c|}
\hline Variable & $\square \square$ & 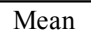 & पणाण口卄 & $\square \square$ & $\square \square$ \\
\hline House Price Growth (YoY) & $\square \square$ & एणाए & पणा & एणाए & पाण \\
\hline House Price-to-Income & $\square$ & एणाए & एणा & पाए & लाए \\
\hline Residential Investment (\% of GDP) & $\square$ & पण口 & पणा। & $\square \square \square$ & पाण \\
\hline FCI & $\square$ & पण口 & पणा। & पाणाए & पा। \\
\hline$\Delta$ Household Debt (\% of GDP) & $\square$ & एणाए & पणा & एणाए & पाए \\
\hline FDI (\% of GDP) & Ш & पणा & पणाप & एापा & एण \\
\hline Other Capital Flows (\% of GDP) & $\square$ & पाए & पणा & एण口 & पाए। \\
\hline Oil (QoQ) & $\square$ & पणा। & पणाए & पण口卄 & पा। \\
\hline
\end{tabular}

Table 4. City-level Summary Statistics

\begin{tabular}{|c|c|c|c|c|c|c|c|c|c|c|c|c|c|}
\hline \multirow{2}{*}{$\frac{\text { United States }}{\text { City }}$} & \multicolumn{5}{|c|}{ 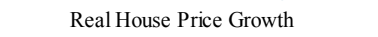 } & \multicolumn{4}{|c|}{ 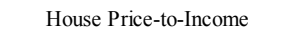 } & \multicolumn{4}{|c|}{ 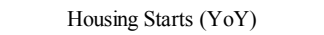 } \\
\hline & $\square \square$ & $\square \square \square$ & 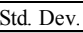 & $\square \square$ & $\square \square$ & 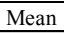 & पणाणाप & $\square \mathbb{1}$ & $\square \square$ & 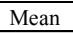 & पणापापाप & $\square \square$ & $\begin{array}{ll}\square \square \\
\end{array}$ \\
\hline Atlanta & $\square$ & पणा & पाणा & पणाए & पाणा & पणाए & पाएा & पाणाए & पाणा & वाण & पाणा & पाणाए & पाणा \\
\hline Austin & $\Pi$ & पणा & पणा। & पणाए & पणाप & पणाए & पणाए & पणाए & पण口 & एणाए & पणा & पण口 & पापाए \\
\hline Boston & $\square$ & पण口 & पणा। & एणा & पणाए & पणा & पणा & पणा & पणाए & पाणा & पणाए & पण口卄 & पणा \\
\hline Charlotte & $\Pi$ & पणा & $\square ण 11$ & पणाए & पाणा & पणाए & एणा & पणाए & पाणा & पणा & पापाए & पाणाए & पणा। \\
\hline Chicago & 110 & पणाप & पणाए & पणा & पाणा & पणाए & पणाए & पणाए & पणा & पणा & पणाए & पाणाए & पणाए \\
\hline Cleveland & $\square$ & पाए & $\square ण 11$ & पण口 & पणाए & पणाए & एण & पणाए & $\square \square$ & पण口 & पण口 & पणा & पणाए \\
\hline Dallas & $\square$ & एणा & पणाए & एण口 & पणाए & पणाए & एणा & पणा & पाणाए & एणा & पणा & पण口 & पणा \\
\hline Denver & 11 & पणा & पणाए & पणम & पाणा & पणाए & पणाए & पणाए & पणा & पणा & पणाए & पाणा & पणाए \\
\hline Detroit & पाए & पापा & पणा & पाणा & पाणा & पणाए & पणा & पणाए & पापा & पापा & पणा & पाण & पणाए \\
\hline Houston & $\square$ & एणा & पणाए & एण口 & पणाए & पणाए & एणा & पणा & पाणाए & एण & पणाए & पण口 & पणा \\
\hline Las Vegas & $\square$ & पणा & पणा। & पणाए & पाणा & पणाए & पणाए & पणाए & पाणा & पणाए & पणाए & पाणाए & पणा \\
\hline Los Angeles & पाए & पापा & पणा & पाणा & पाणा & पणाए & पणा & पणाए & पणा & पणाप & पणा & पाण & पणाए \\
\hline Miami & पा & पणा & पणा। & पणा & पणा & पणाए & पणाए & वाण & पणाप & पणमा & पणाए & पाயए & पणा \\
\hline Minne apolis & 11 & पणाए & पणा। & पणाए & पाणा & पणाए & पणाए & पणाए & पाणा & पणा & पणाए & पाणाए & पणा \\
\hline New York & $\square$ & पणाए & पणा। & पणा & पणा & पणाए & पणाए & वणा & पण口 & पाणाए & पणा & पण口卄 & पणाए \\
\hline Philadelphia & Шा & पणा & पणा & पाण & पाणा & पणाए & पणा & वणा & पणाए & पणा & पणाए & एण口 & पणा \\
\hline Phoenix & 11 & पणा। & वणा। & पणाए & पणाप & पणाए & पणाए & पणाए & पणाए & पणाए & पाणा & पाणाए & पणा \\
\hline Portland & $\square$ & पणाप & पणा। & पणाए & पणा & पणाए & पणाए & पणाए & पापा & पाणा & पणाए & पणाए & पणाए \\
\hline San Diego & $\square$ & पणा & पणाए & पणा & पणाए & पणाए & पणा & पणाए & पाणाए & पण口 & पणा & पण口卄 & पणा \\
\hline San Francisco & 11 & पणा & पणाए & पाणा & पणाए & एणाए & पणाए & पणाए & पणाए & पणा & पाणा & पाणा & पणा \\
\hline Seattle & 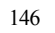 & पाणा & पणा & पणाए & पणाए & पणा & पणा & पणाए & पणाए & पणा & पणा & पाणा & पणा \\
\hline Tampa & $\square$ & पणाप & पणाए & पाणा & पणाए & पणाए & पणा & पणाए & पाणाए & पण口卄 & पणा & पण口卄 & पणा \\
\hline Washington DC & $\square$ & पणा & $\square ण 10$ & एणा & $\square ण 1$ & एणाए & एवा & $\square ण 1$ & एवा & पणा & पणाप & पण口卄 & पणाए \\
\hline
\end{tabular}

\begin{tabular}{|c|c|c|c|c|c|c|c|c|c|c|c|c|c|}
\hline Canada & & 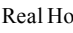 & \|\|\|\|\|\||| & पण口卄 & & & \|\|\|\|$\|$ & 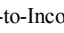 & & 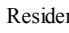 & $\mid\|\|\|\|\|\|\|\|$ & 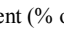 & Iपिए। \\
\hline City & $\square \square$ & $\square \square \square$ & पापाणाप & $\square \square$ & $\square \square$ & $\square \square$ & पणाणाप & $\square \mathbb{U}$ & $\square \square$ & $\square \square$ & 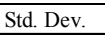 & $\square \square$ & $\begin{array}{ll}\square \square \\
\end{array}$ \\
\hline Calgary & $\square$ & $\square \square \square$ & पण1। & 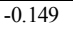 & पाणाए & पणाए & पाणाए & पाणा & पापाए & $\square \square \square$ & पापा & पाणाए & $\square 011$ \\
\hline Edmonton & $\square$ & एणए & $\square \square \square$ & पणा & पणा & पणाए & पणाए & पणा & पणाए & पणाप & एणा & पणाए & पणाए \\
\hline Hamilton & $\square$ & एण & पणा & एणा & पणाए & पणा & पणाप & पणाए & पणाए & पणा & एणा & पणाप & पणाए \\
\hline London & $\square$ & एणा & पणा & पणा & पाणा & पणाप & पणाप & पणाए & पाणा & पणाप & पाण & पाणाप & पाणा \\
\hline Montreal & प11 & पणा & पणा & एणाए & पणाए & पणा म्या - & 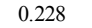 & पणाए & पणाए & 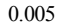 & पणा मा & पणाए & पणा। \\
\hline Quebec City & $\square$ & एण & पणा & एणा & पणाए & पणा & पणाप & पणाए & पणाए & पणा & एणा & पणाप & $\square ण 11$ \\
\hline Regina & 11 & पणाप & $\square \Pi 10$ & पालाए & पणाप & $\square \square \square$ & पाणा & पाणाप & पाणाप & पणाप & पाणा & पाणाप & पणाप \\
\hline Toronto & $\Pi 1$ & पणाए & पामा & पणाए & पणाए & पणाए & पणाप & पणाए & पाणा & पणाप & पाएा & पणाप & पणाए \\
\hline Vancouver & Шा & एणा & पणा & एणा & पणाए & पणाप म्या & एणाए & पणाए & पणाए & 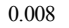 & एलाए मा म & पणाए & एणाए \\
\hline Victoria & 11 & पणाए & $\square \Pi 10$ & पालाए & पणाप & पणाप & पाणा & पाणाप & पणाए & पणाप & पाणा & पाणाप & पणाप \\
\hline Winds or & 11 & पणाए & पाण & पाणा & पणाप & पणाप & पाणा & पाणाप & पणा & पाणा & पणाप & पाणा & पणाए \\
\hline Winnipeg & $\square$ & एणा & पण口 & Шण口 & 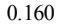 & पणाए & पणाए & एणाए & पणा & 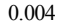 & पणा & पा山ाप & पणाए \\
\hline Ottawa & $\square$ & एणा & $\square \square$ & पणा & पणाए & पणाप & पणाए & पणाए & पाणा & पणाप & पाए & पाणा & पणाए \\
\hline Greater Sudbury & $\square$ & पाणा & पाण & पाणा & पणाप & पणाप & पाणा & पाणाप & पणा & पणाए & पणाए & पाणा & पणाए \\
\hline St. Catharines & $\square$ & पणा & पणा & पणाए & पणाए & पणा & पणाए & पणाए & $\square \mathrm{IIL}$ & पणा & पणाए & पाणा & पणा। \\
\hline
\end{tabular}


ANNEX

\section{Annex Figure 1. Household Balance Sheets: Canada vs United States}
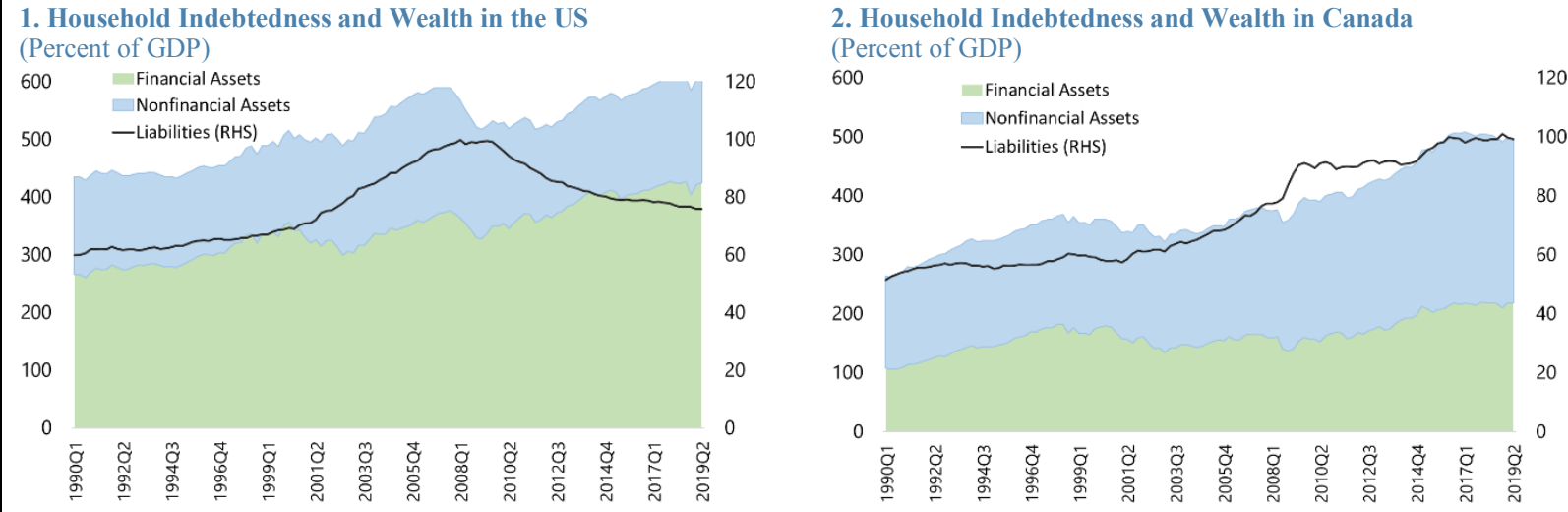

3. Composition of Household Debt in the US

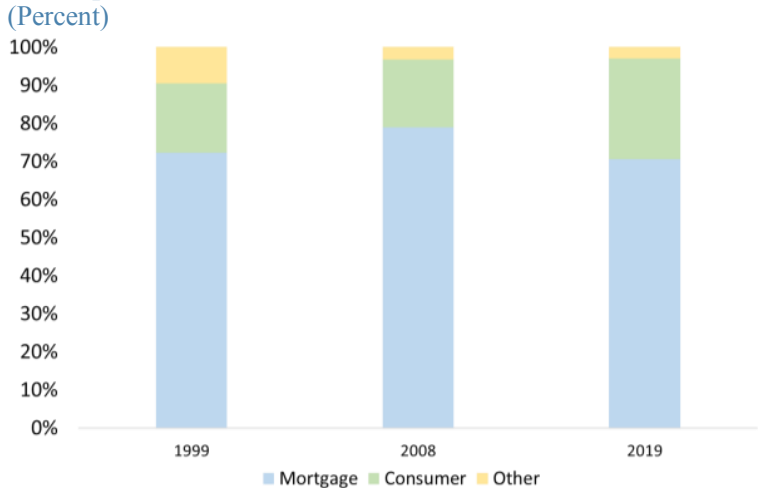

4. Composition of Household Debt in Canada

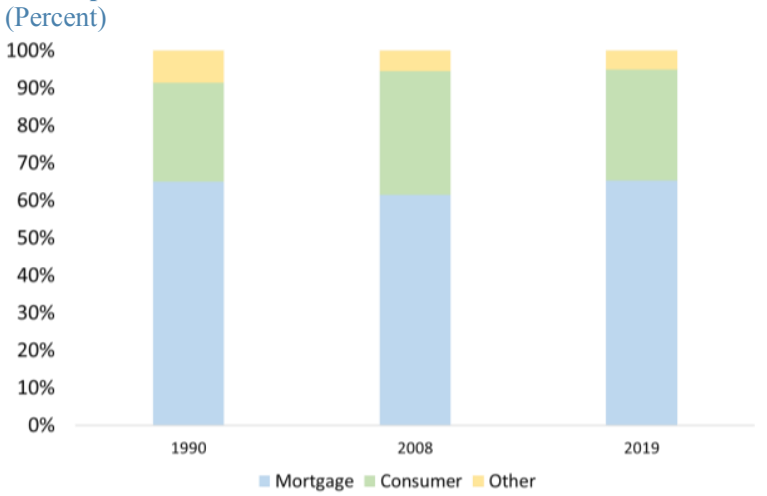

5. Real Estate Wealth and Consumption in the US

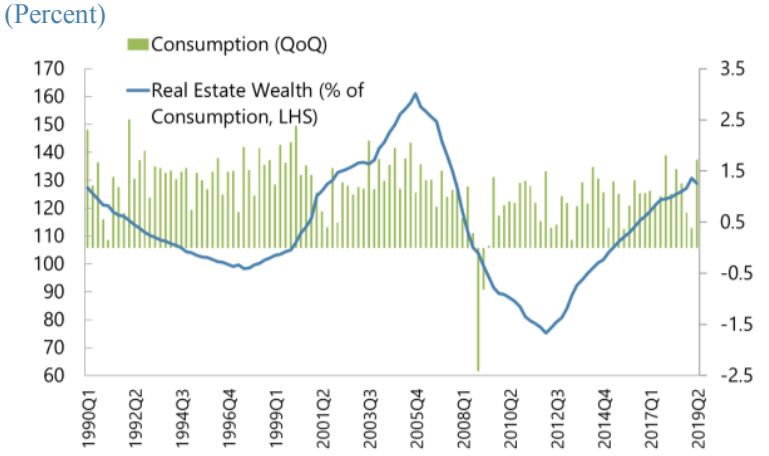

6. Real Estate Wealth and Consumption in Canada

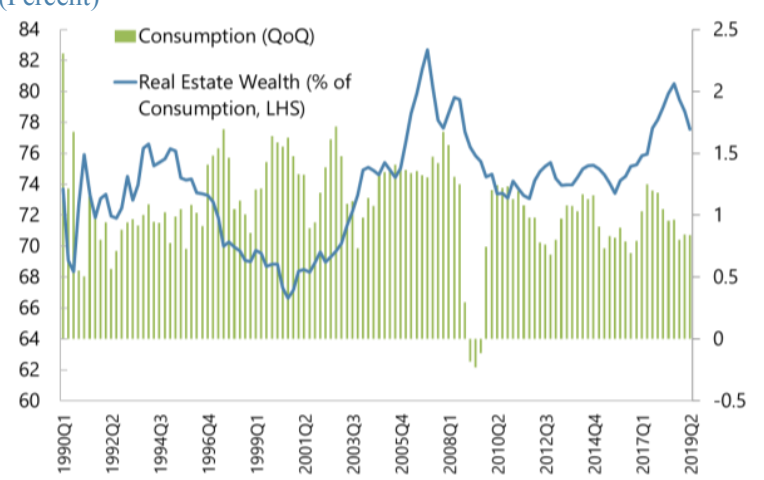




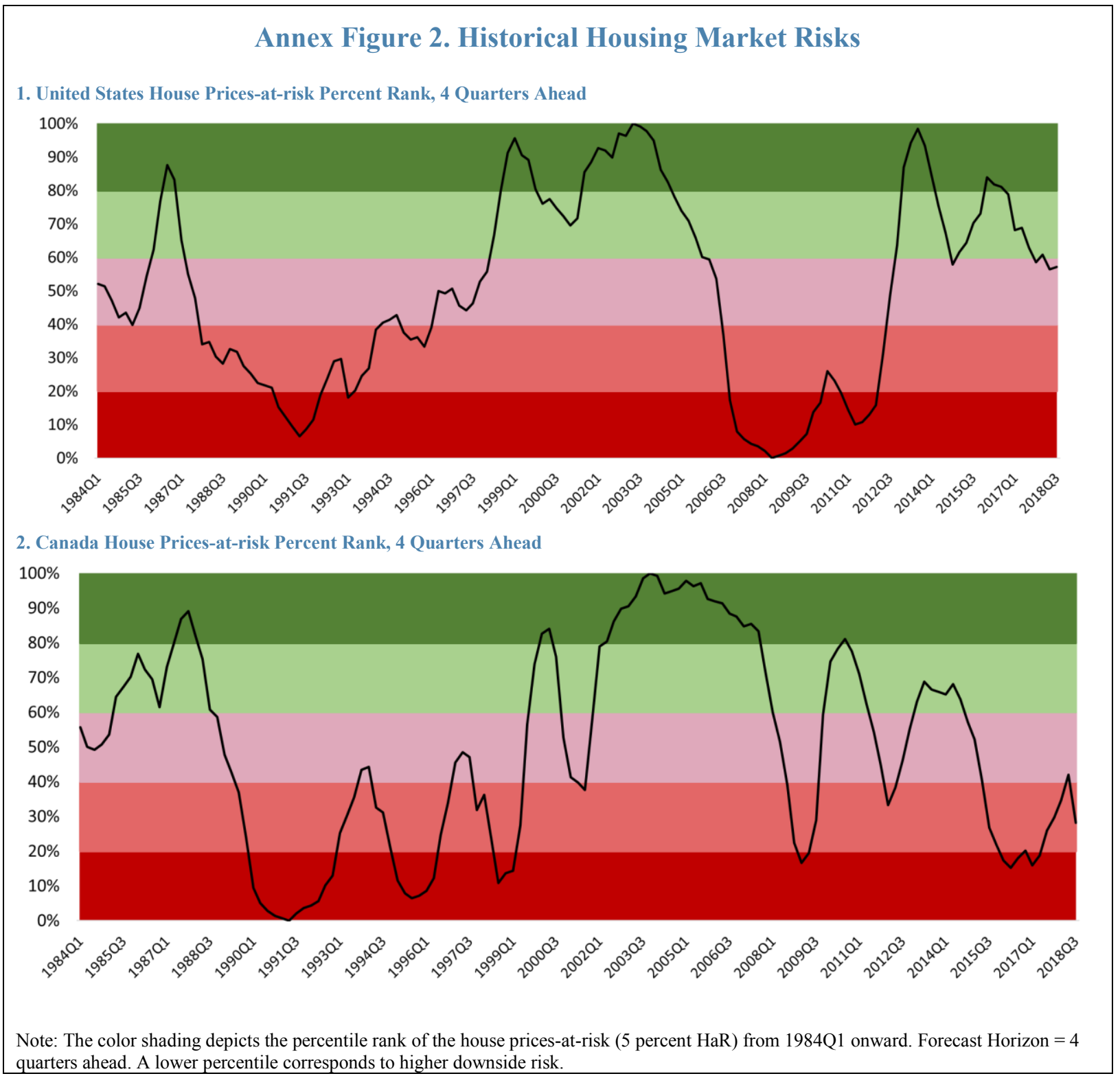




\section{Annex Figure 3. Drivers of Long-term House Prices-at-risk}

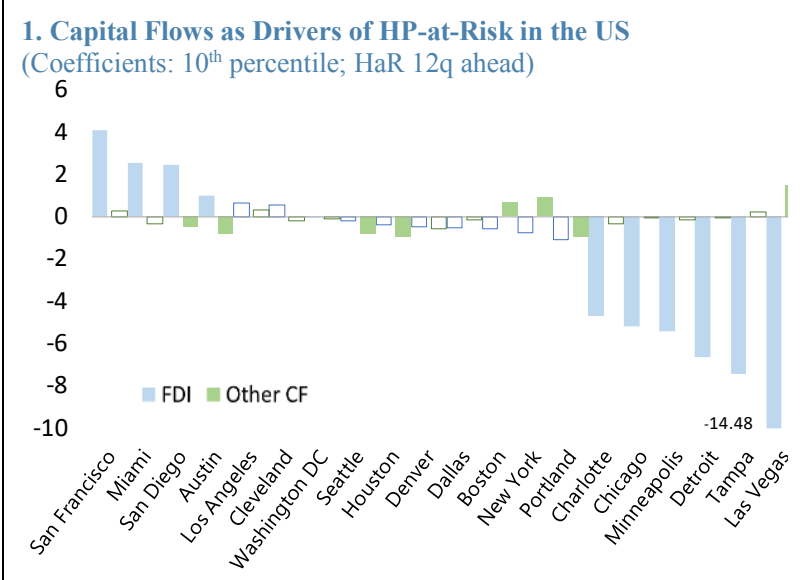

3. Sensitivity of House Price-at-Risk to Financial Conditions in the US

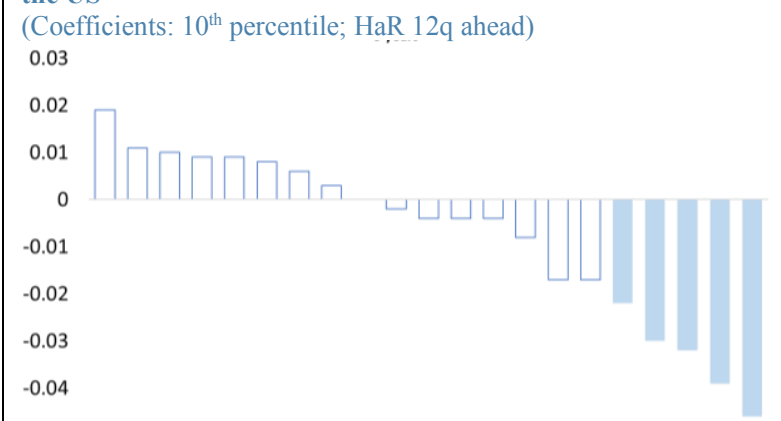

$-0.05$

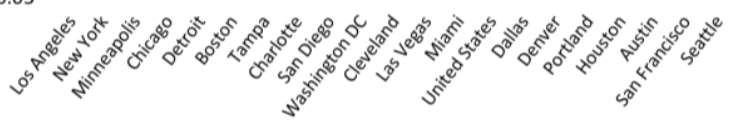

5. Sensitivity of House Price-at-Risk to Household Debt in the US

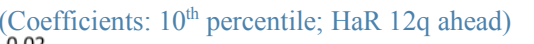

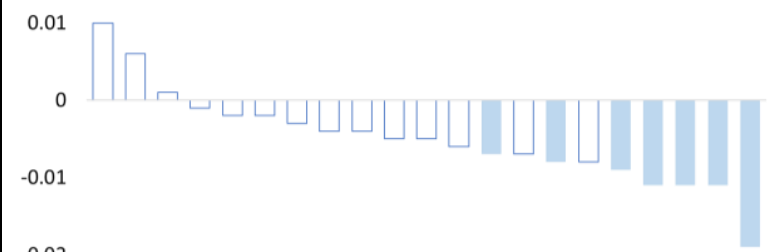

$-0.02$

$-0.03$

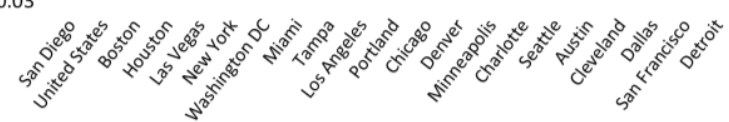

2. Capital Flows as Drivers of HP-at-Risk in Canada

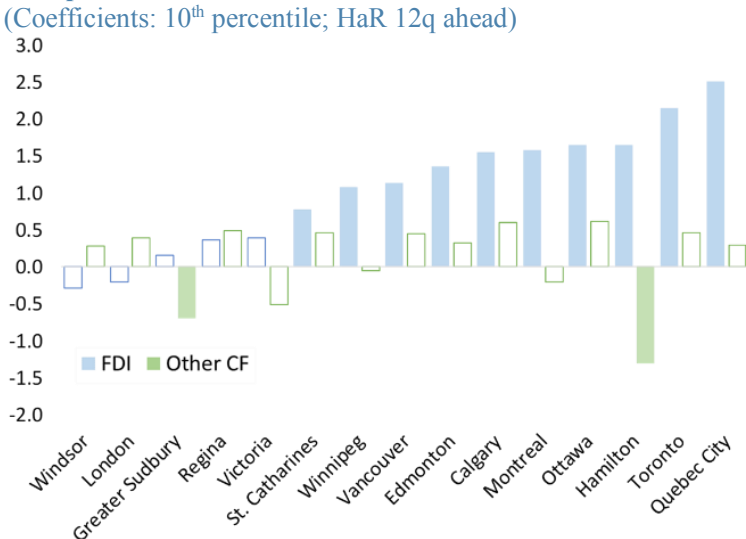

4. Sensitivity of House Price-at-Risk to Financial Conditions in Canada

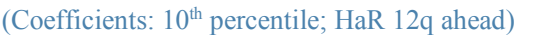

0.08

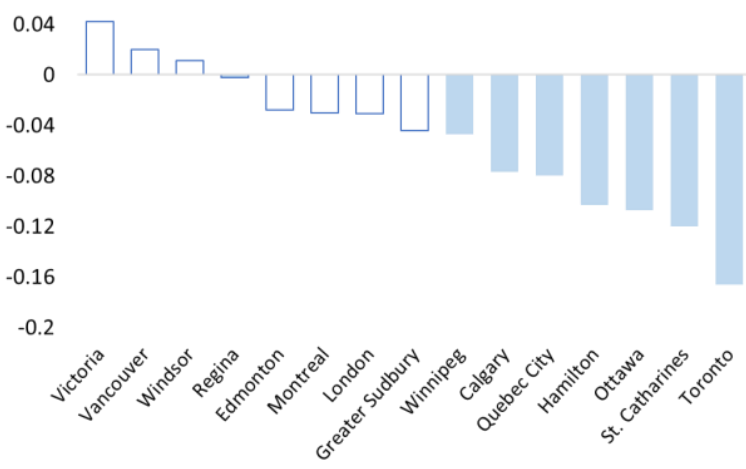

6. Sensitivity of House Price-at-Risk to Household Debt in Canada

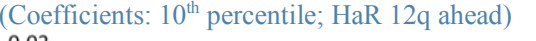

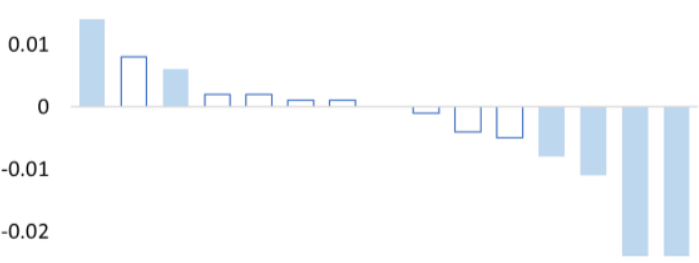

$-0.03$

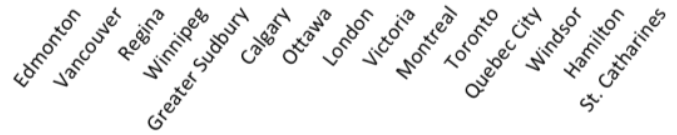


Annex Figure 4. Foreign Openness and Sensitivity to Capital Inflows

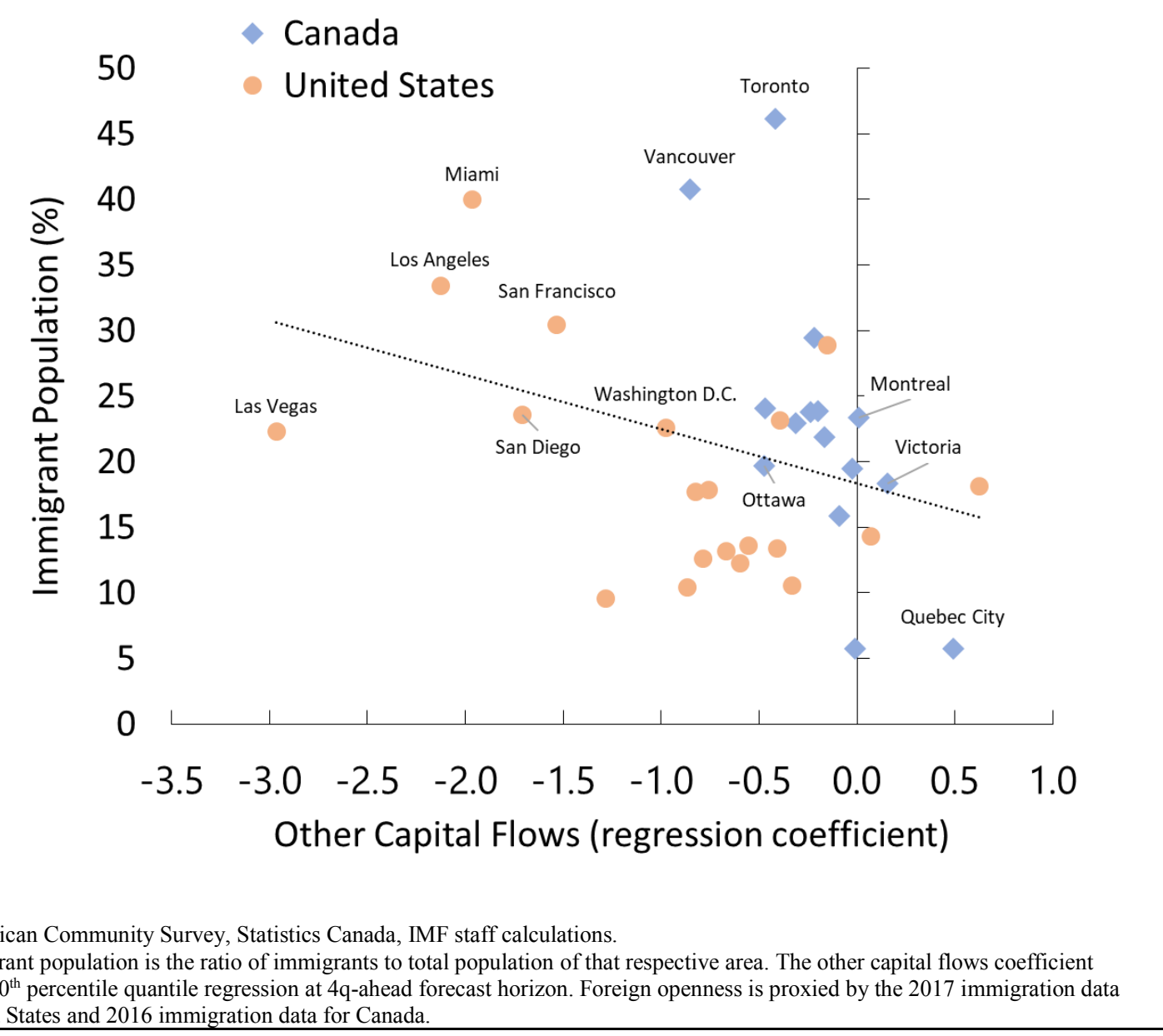




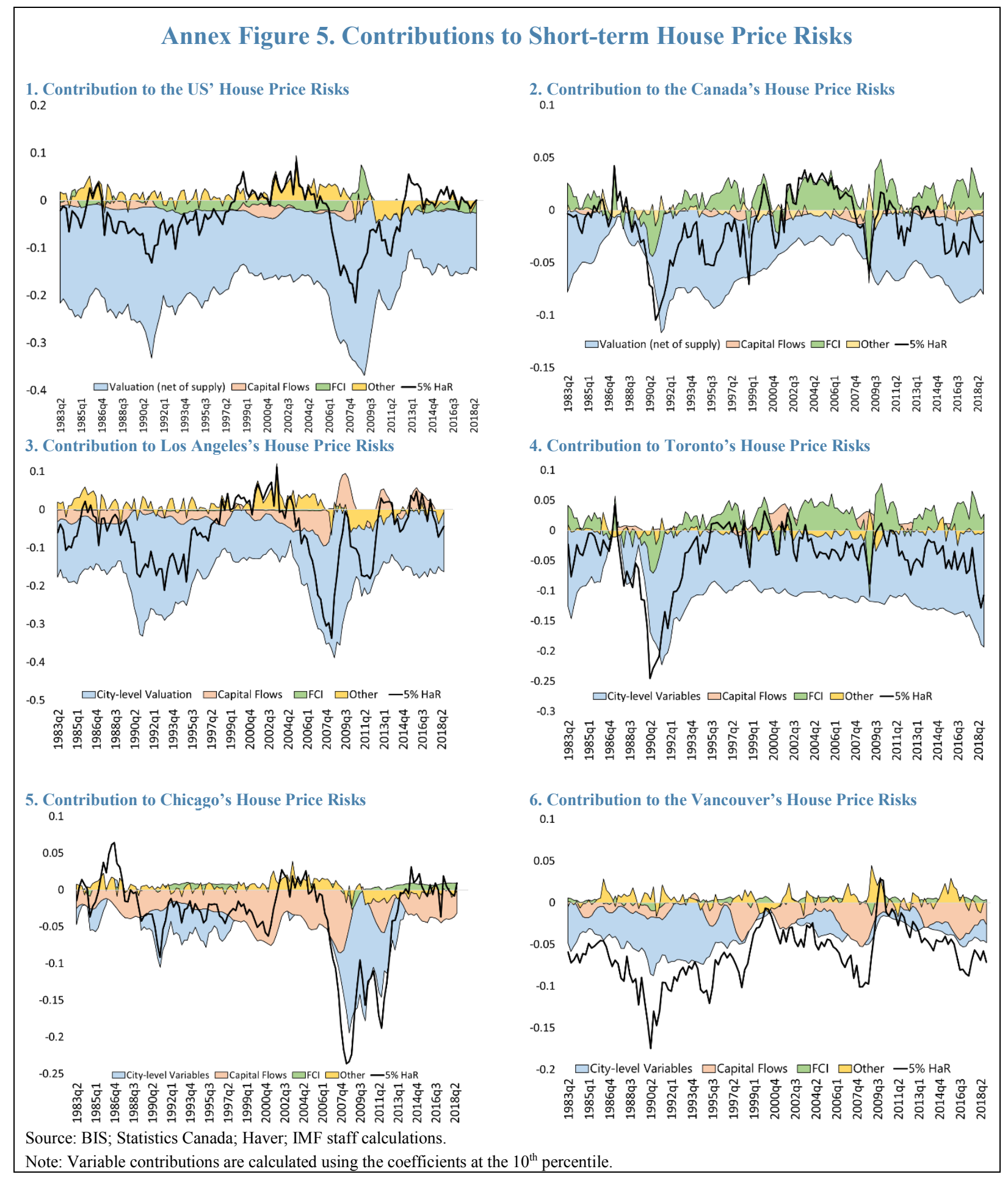

CInternational Monetary Fund. Not for Redistribution 
$\square \square$

Annex Table 1. United States: Short-term City-level Coefficients

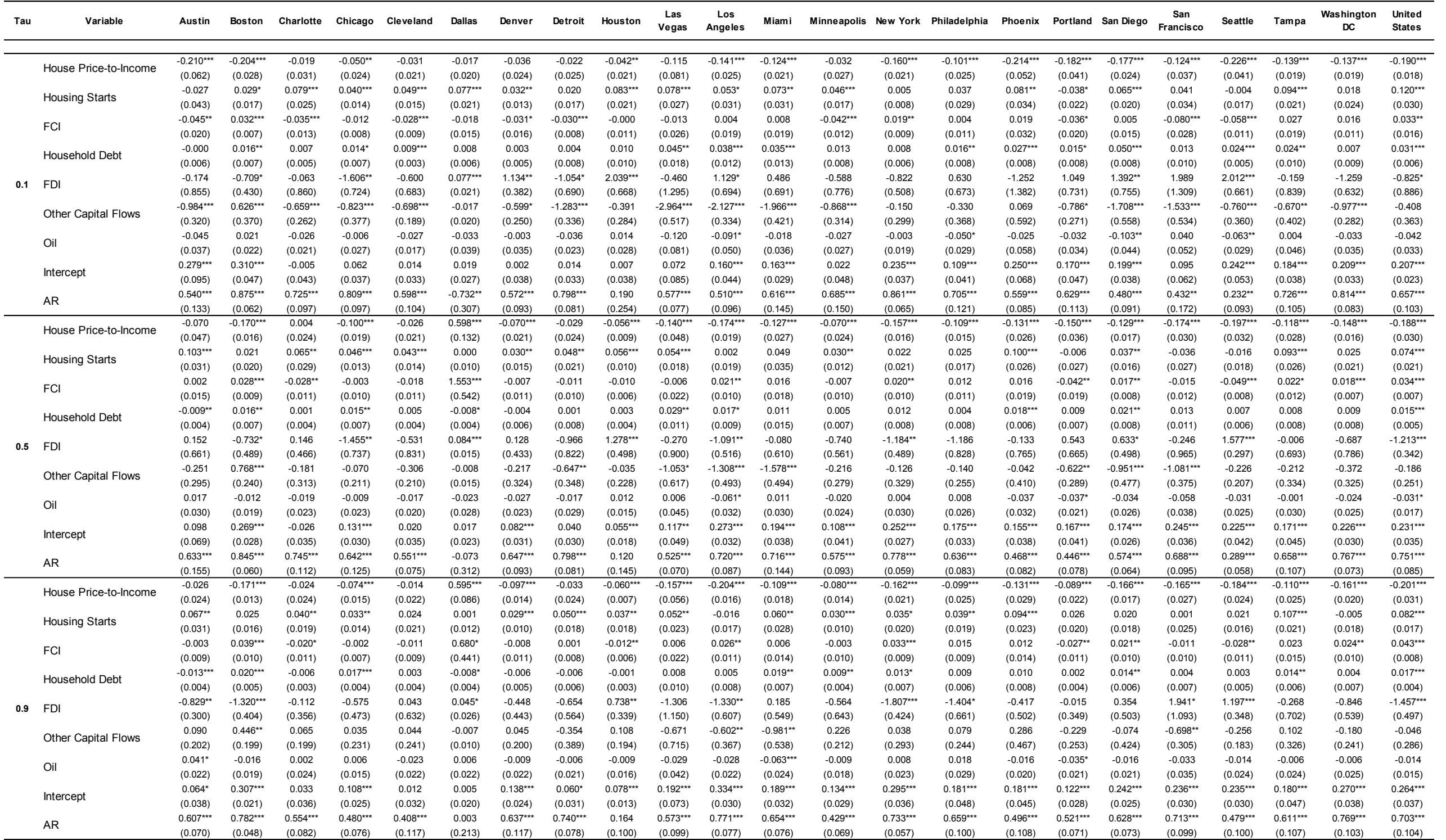

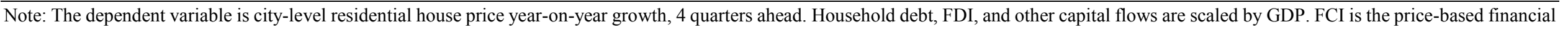

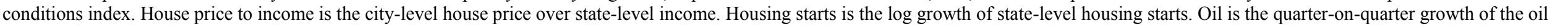

पालाणाएण 
$\square \square$

Annex Table 2. Canada: Short-term City-level Coefficients

\begin{tabular}{|c|c|c|c|c|c|c|c|c|c|c|c|c|c|c|c|c|c|}
\hline Tau & Variable & Calgary & Edmonton & Ham ilton & London & Montreal & Quebec City & Regina & Toronto & Vancouver & Victoria & Windsor & Winnipeg & Ottawa & $\begin{array}{l}\text { Greater } \\
\text { Sudbury }\end{array}$ & $\begin{array}{c}\text { St. } \\
\text { Catharines } \\
\end{array}$ & Canada \\
\hline \multirow{18}{*}{0.1} & \multirow[b]{2}{*}{ House Price-to-Income } & $-0.249^{*+*}$ & $-0.244^{* * *+\pi}$ & -0.016 & $-0.075^{* * *+1}$ & -0.001 & $-0.073^{*+*}$ & -0.024 & $-0.065^{* *}$ & $0.037^{* *}$ & $0.079^{* * *}$ & -0.024 & 0.017 & $-0.101^{*+*+*}$ & -0.010 & 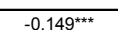 & $-0.187^{7+* x}>0$ \\
\hline & & $(0.093)$ & $(0.028)$ & $(0.028)$ & $(0.020)$ & $(0.011)$ & $(0.014)$ & $(0.022)$ & $(0.029)$ & $(0.018)$ & $(0.021)$ & $(0.040)$ & $(0.017)$ & $(0.021)$ & $(0.012)$ & $(0.043)$ & $(0.036)$ \\
\hline & \multirow{2}{*}{ Residential Investment } & -3.849 & $7.954^{* *}$ & $-13.114^{*}$ & $9.007^{+2+x}$ & 1.321 & $12.668^{* \star *}$ & $-4.731^{* \star *}$ & $-12.629^{* *}$ & $-9.040^{* * *}$ & $-10.669^{* * * *}$ & $5.291^{*}$ & $-4.110^{* *}$ & $13.839^{* * *}$ & $8.849^{*+*}$ & 8.655 & $7.391^{* *+*}$ \\
\hline & & $(6.678)$ & $(3.371)$ & $(7.050)$ & $(2.735)$ & $(1.777)$ & $(1.817)$ & $(1.582)$ & $(6.192)$ & $(1.422)$ & $(3.028)$ & (3.149) & $(1.859)$ & $(2.184)$ & $(1.565)$ & $(6.684)$ & (1.509) \\
\hline & \multirow{2}{*}{$\mathrm{FCl}$} & $-0.056^{* *}$ & $-0.049^{* *}$ & $-0.031^{*}$ & $-0.031^{* * *}$ & $-0.017^{* *}$ & $-0.015^{* *}$ & -0.022 & $-0.111^{* * * *}$ & -0.015 & -0.017 & -0.008 & $-0.019^{* * *}$ & $-0.058^{+\operatorname{tax}}$ & -0.006 & $-0.055^{n+*}$ & $-0.069^{\text {tox }}$ \\
\hline & & $(0.024)$ & $(0.019)$ & $(0.017)$ & $(0.010)$ & $(0.008)$ & $(0.007)$ & $(0.016)$ & $(0.025)$ & $(0.013)$ & $(0.020)$ & $(0.007)$ & $(0.005)$ & $(0.013)$ & $(0.006)$ & $(0.016)$ & $(0.017)$ \\
\hline & \multirow{2}{*}{ Household Debt } & $0.020^{* *}$ & $0.028^{t+x+x}$ & $0.007^{*}$ & $0.005^{*}$ & $0.005^{* t+*}$ & -0.000 & $0.010^{* *}$ & -0.004 & 0.010 & 0.004 & -0.002 & 0.001 & 0.002 & 0.002 & -0.003 & -0.002 \\
\hline & & $(0.008)$ & $(0.004)$ & $(0.004)$ & $(0.003)$ & $(0.002)$ & $(0.003)$ & $(0.004)$ & $(0.006)$ & $(0.006)$ & $(0.004)$ & $(0.003)$ & $(0.003)$ & $(0.005)$ & $(0.002)$ & $(0.007)$ & $(0.005)$ \\
\hline & \multirow{2}{*}{ FDI } & $1.037^{\text {tot }}$ & -0.520 & 0.217 & 0.104 & 0.024 & $0.733^{+*+*}$ & -0.044 & $0.536^{t+x}$ & -0.341 & -0.350 & $0.294^{t+x+x}$ & 0.056 & $0.684^{t+x+}$ & -0.014 & $0.274^{*}$ & -0.115 \\
\hline & & $(0.357)$ & $(0.318)$ & $(0.135)$ & $(0.110)$ & $(0.122)$ & $(0.060)$ & $(0.187)$ & $(0.198)$ & $(0.217)$ & $(0.260)$ & $(0.114)$ & $(0.084)$ & $(0.191)$ & $(0.072)$ & $(0.155)$ & $(0.221)$ \\
\hline & \multirow{2}{*}{ Other Capital Flows } & -0.219 & -0.239 & $-0.469^{*}$ & -0.023 & 0.011 & $0.493^{\text {t*x}}$ & -0.091 & -0.416 & $-0.853^{* * *+4}$ & 0.156 & $-0.313^{*}$ & $-0.198^{* *}$ & $-0.472^{* *}$ & -0.012 & $0.586^{* *}$ & -0.165 \\
\hline & & $(0.571)$ & $(0.259)$ & $(0.266)$ & $(0.146)$ & $(0.121)$ & $(0.105)$ & $(0.271)$ & $(0.319)$ & $(0.227)$ & $(0.296)$ & $(0.175)$ & $(0.090)$ & $(0.223)$ & $(0.149)$ & $(0.268)$ & $(0.194)$ \\
\hline & \multirow{2}{*}{ Oil } & 0.030 & -0.018 & -0.014 & -0.010 & -0.014 & -0.002 & -0.016 & -0.057 & $-0.050^{*}$ & -0.005 & -0.014 & $-0.019^{* *}$ & -0.028 & 0.000 & 0.025 & -0.038 \\
\hline & & $(0.043)$ & $(0.042)$ & $(0.024)$ & $(0.022)$ & $(0.010)$ & $(0.011)$ & $(0.022)$ & $(0.039)$ & $(0.028)$ & $(0.028)$ & $(0.015)$ & $(0.008)$ & $(0.020)$ & $(0.009)$ & $(0.041)$ & $(0.033)$ \\
\hline & \multirow{2}{*}{ Intercept } & $0.171^{+*+x}$ & $0.144^{+*+x}$ & $0.056^{* *}$ & 0.018 & $-0.012^{*}$ & $-0.026^{*+* *}$ & $0.033^{\text {tot }}$ & $0.072^{*}$ & 0.016 & -0.030 & -0.024 & -0.003 & -0.007 & $-0.052^{*+*}$ & 0.055 & $0.052^{*+*+}$ \\
\hline & & $(0.047)$ & $(0.025)$ & $(0.028)$ & $(0.026)$ & $(0.007)$ & $(0.010)$ & $(0.011)$ & $(0.037)$ & $(0.019)$ & $(0.027)$ & $(0.038)$ & $(0.008)$ & $(0.016)$ & $(0.012)$ & $(0.047)$ & $(0.013)$ \\
\hline & \multirow{2}{*}{ AR } & $0.245^{\text {tot }}$ & $0.136^{*}$ & $0.758^{t+t+x}$ & $0.162^{*}$ & $0.390^{* t+*}$ & $0.238^{+\ldots+x}$ & $0.171^{* *}$ & $0.559^{+*+*}$ & 0.079 & $0.399^{t+4 x}$ & $0.328^{*}$ & $0.375^{+2+x}$ & -0.040 & $0.218^{* *}$ & 0.171 & $0.291^{* *}$ \\
\hline & & $(0.075)$ & $(0.073)$ & $(0.226)$ & $(0.088)$ & $(0.060)$ & $(0.084)$ & $(0.073)$ & $(0.125)$ & $(0.075)$ & $(0.152)$ & $(0.178)$ & $(0.076)$ & $(0.075)$ & $(0.085)$ & $(0.202)$ & $(0.126)$ \\
\hline \multirow{17}{*}{0.5} & \multirow{2}{*}{ House Price-to-Income } & $-0.137^{* *+x}$ & $-0.081^{t+* x}$ & -0.021 & $-0.082^{* * t}$ & $-0.044^{* * *+}$ & $-0.091^{* * * t}$ & $-0.034^{* *}$ & $-0.038^{* *}$ & -0.032 & -0.013 & $-0.106^{* * t}$ & $-0.040^{* * * t}$ & $-0.089^{t+4+}$ & $-0.020^{+*+*}$ & $-0.098^{t+4+x}$ & $-0.147^{*+*+1}$ \\
\hline & & $(0.036)$ & $(0.025)$ & $(0.015)$ & $(0.010)$ & $(0.010)$ & $(0.014)$ & $(0.015)$ & $(0.017)$ & $(0.021)$ & $(0.018)$ & $(0.033)$ & $(0.015)$ & $(0.023)$ & $(0.007)$ & $(0.021)$ & $(0.041)$ \\
\hline & \multirow{2}{*}{ Residential Investment } & -4.071 & 0.859 & 0.816 & $11.616^{*+*+}$ & $3.265^{*}$ & $8.294^{1+*+*}$ & -2.413 & 2.102 & -4.135 & $-8.769^{* *+*}$ & 2.774 & $3.853^{*}$ & $7.228^{\text {tot }}$ & $6.369^{t+*}$ & 2.902 & $5.153^{*+*+}$ \\
\hline & & $(3.476)$ & $(2.862)$ & $(3.628)$ & $(2.601)$ & $(1.881)$ & $(1.436)$ & (1.789) & $(3.880)$ & (3.807) & $(1.765)$ & (2.240) & $(2.165)$ & $(2.123)$ & $(1.791)$ & (3.831) & $(1.742)$ \\
\hline & \multirow{2}{*}{$\mathrm{FCl}$} & $-0.064^{* *+*}$ & $-0.050^{* * *}$ & $-0.043^{* *}$ & $-0.027^{* * * *}$ & $-0.032^{* * *}$ & $-0.009^{*}$ & $-0.025^{* * *}$ & $-0.060^{* * * *}$ & -0.014 & -0.013 & -0.013 & $-0.038^{* * *}$ & $-0.037^{* * *}$ & -0.006 & $-0.041^{* *}$ & $-0.023^{* *}$ \\
\hline & & $(0.016)$ & $(0.011)$ & $(0.017)$ & $(0.005)$ & $(0.006)$ & $(0.005)$ & $(0.008)$ & $(0.016)$ & $(0.021)$ & $(0.016)$ & $(0.011)$ & $(0.007)$ & $(0.012)$ & $(0.006)$ & $(0.016)$ & $(0.009)$ \\
\hline & & 0.007 & $0.012^{* * * x}$ & 0.000 & 0.002 & $0.004^{*}$ & -0.000 & $0.011^{\text {t*** }}$ & 0.002 & $0.020^{*+* x}$ & $0.013^{*+* x}$ & -0.000 & $0.007^{*+*}$ & 0.005 & -0.000 & 0.001 & $0.005^{*+*+}$ \\
\hline & Household Debt & $(0.004)$ & $(0.004)$ & $(0.002)$ & $(0.002)$ & $(0.002)$ & $(0.001)$ & $(0.003)$ & $(0.003)$ & $(0.005)$ & $(0.004)$ & $(0.003)$ & $(0.002)$ & $(0.003)$ & $(0.002)$ & $(0.003)$ & $(0.002)$ \\
\hline & & $0.347^{* *}$ & -0.202 & 0.161 & 0.070 & $0.432^{+*+*}$ & $0.626^{t+4+x}$ & 0.053 & $0.316^{* *}$ & -0.260 & -0.051 & -0.127 & $-0.231^{* *}$ & $0.484^{+*+*}$ & -0.029 & 0.003 & -0.161 \\
\hline & FDI & $(0.171)$ & $(0.368)$ & $(0.170)$ & $(0.061)$ & $\begin{array}{l}(0.090) \\
(0.090\end{array}$ & $(0.123)$ & $(0.164)$ & $(0.145)$ & $(0.245)$ & $(0.201)$ & $(0.098)$ & $(0.104)$ & $(0.165)$ & $(0.078)$ & $(0.166)$ & $(0.148)$ \\
\hline & Other Capital Flows & -0.128 & $-0.447^{* *}$ & -0.226 & 0.037 & -0.010 & $0.465^{t+2 x}$ & -0.057 & -0.126 & -0.171 & -0.134 & -0.012 & 0.060 & -0.206 & -0.047 & $0.421^{*}$ & $-0.364^{* *}$ \\
\hline & Utner Capital riows & $(0.269)$ & $(0.193)$ & $(0.219)$ & $(0.093)$ & $(0.092)$ & $(0.093)$ & $(0.218)$ & $(0.144)$ & $(0.505)$ & $(0.222)$ & $(0.163)$ & $(0.177)$ & $(0.249)$ & $(0.127)$ & $(0.248)$ & $(0.151)$ \\
\hline & Oil & -0.026 & -0.018 & -0.023 & -0.003 & -0.004 & -0.005 & 0.012 & $-0.051^{1 *}$ & -0.036 & 0.033 & -0.008 & $-0.022^{* *}$ & -0.014 & -0.006 & -0.027 & $-0.024^{*}$ \\
\hline & & $(0.020)$ & $(0.021)$ & $(0.024)$ & $(0.008)$ & $(0.011)$ & $(0.012)$ & $(0.015)$ & $(0.023)$ & $(0.029)$ & $(0.038)$ & $(0.014)$ & $(0.011)$ & $(0.013)$ & $(0.010)$ & $(0.022)$ & $(0.014)$ \\
\hline & Intercept & $\begin{array}{l}0.144^{+4 * *+} \\
(0.018)\end{array}$ & $\begin{array}{l}0.077^{*+*} \\
(0.020)\end{array}$ & $\begin{array}{c}0.016 \\
(0.016)\end{array}$ & $\begin{array}{l}0.030^{*} \\
(0.017)\end{array}$ & $\begin{array}{c}0.014 \\
(0.009)\end{array}$ & $\begin{array}{l}0.028^{+\ldots+*} \\
0.009)\end{array}$ & $\begin{array}{l}0.045^{*+*} \\
0.011)\end{array}$ & $\begin{array}{c}0.018 \\
(0.023)\end{array}$ & $\begin{array}{l}0.065^{* *+*} \\
(0.022)\end{array}$ & $0.080^{+*+x}$ & $0.098^{* *}$ & $\begin{array}{l}0.036^{+2 *+1} \\
(0.012)\end{array}$ & $0.039^{*}$ & -0.011 & $0.077^{* * *+}$ & $0.077^{* * *}$ \\
\hline & & $0.222^{* *}$ & $0.396^{+* t+2}$ & $\begin{array}{l}(0.016) \\
0.605^{*+*}\end{array}$ & $\begin{array}{l}(0.017) \\
0.096\end{array}$ & $\begin{array}{l}(0.009) \\
0.520^{+4 *+}\end{array}$ & $\begin{array}{l}(0.009) \\
0.386^{* * *}\end{array}$ & $\begin{array}{l}(0.011) \\
0.558^{+*+*}\end{array}$ & $\begin{array}{l}(0.023) \\
0.474^{*+*}\end{array}$ & $\begin{array}{l}(0.022) \\
0.462^{*+*}\end{array}$ & $\begin{array}{l}(0.021) \\
0.740^{* *+*}\end{array}$ & $\begin{array}{l}(0.038) \\
0.261^{* *}\end{array}$ & $\begin{array}{l}(0.012) \\
0.475^{* *+*}\end{array}$ & $\begin{array}{l}(0.021) \\
0.287^{*+*+*}\end{array}$ & $\begin{array}{l}(0.011) \\
0.286^{* *+*}\end{array}$ & $\begin{array}{l}(0.018) \\
0.469^{*+*}\end{array}$ & $\begin{array}{l}(0.017) \\
0.445^{* * *}\end{array}$ \\
\hline & AR & $(0.099)$ & $(0.087)$ & $(0.093)$ & $\begin{array}{l}(0.102) \\
\end{array}$ & $(0.080)$ & $(0.070)$ & $(0.127)$ & $(0.085)$ & $(0.125)$ & $(0.078)$ & $(0.114)$ & $(0.106)$ & $(0.109)$ & $(0.099)$ & $(0.098)$ & $(0.067)$ \\
\hline & & -0.081 & $-0.201^{\text {t* }}$ & $-0.058^{*+* *}$ & $-0.205^{* * *}$ & $-0.062^{* *+*}$ & $-0.122^{*+* t}$ & $-0.058^{*+* t}$ & $-0.150^{* * * *}$ & $-0.131^{+*+*}$ & $-0.116^{*+* t}$ & $-0.163^{2+x+4}$ & -0.039 & $-0.120^{t+x+4}$ & $-0.090^{*+*}$ & $-0.154^{+*+x}$ & $-0.168^{x+x+x}$ \\
\hline & House Price-to-Income & $(0.096)$ & $(0.083)$ & $(0.015)$ & $(0.030)$ & $(0.018)$ & $(0.020)$ & $(0.021)$ & $(0.033)$ & $(0.021)$ & $(0.019)$ & $(0.023)$ & $(0.028)$ & $(0.019)$ & $(0.036)$ & $(0.026)$ & $(0.058)$ \\
\hline & & -8.799 & -7.906 & -1.540 & $13.137^{*}$ & 1.053 & $13.473^{* \star *}$ & -0.891 & $40.126^{* * *}$ & 7.334 & $-9.961^{* \star *}$ & 3.521 & -0.286 & 2.667 & $16.107^{* * *}$ & $10.875^{* \star *}$ & 3.702 \\
\hline & Residential Investment & $(10.870)$ & $(6.979)$ & $(3.875)$ & $(6.885)$ & $(3.025)$ & $(3.199)$ & $(3.518)$ & $(7.586)$ & $(6.160)$ & $(3.278)$ & $(2.525)$ & $(5.806)$ & $(3.533)$ & $(2.344)$ & $(2.610)$ & $(2.878)$ \\
\hline & $\mathrm{FCl}$ & -0.031 & $-0.069^{*}$ & $-0.029^{*}$ & $-0.043^{* * *+}$ & $-0.031^{* *+*}$ & -0.009 & $-0.056^{* * * *}$ & $-0.087^{* * *}$ & 0.020 & -0.020 & $-0.040^{* * * *}$ & $-0.035^{* * *}$ & $-0.055^{* * *}$ & $-0.019^{+* *}$ & -0.025 & -0.021 \\
\hline & $\mathrm{FCl}$ & $(0.041)$ & $(0.036)$ & $(0.016)$ & $(0.011)$ & $(0.011)$ & $(0.008)$ & $(0.016)$ & $(0.029)$ & $(0.031)$ & $(0.017)$ & $(0.011)$ & $(0.013)$ & $(0.014)$ & $(0.010)$ & $(0.022)$ & $(0.016)$ \\
\hline & Household Debt & 0.013 & $0.015^{* *}$ & 0.003 & $0.006^{* *+}$ & 0.002 & -0.003 & 0.004 & $0.014^{*}$ & $0.019^{+* t *}$ & $0.017^{*+* x}$ & $0.014^{* * *}$ & $0.015^{+2+4}$ & -0.004 & $0.008^{*}$ & $0.007 * *$ & $0.012^{* * *+}$ \\
\hline & Monsenoria Dede & $(0.011)$ & $(0.007)$ & $(0.004)$ & $(0.003)$ & $(0.002)$ & $(0.002)$ & $(0.004)$ & $(0.008)$ & $(0.005)$ & $(0.005)$ & $(0.006)$ & $(0.005)$ & $(0.005)$ & $(0.005)$ & $(0.004)$ & $(0.003)$ \\
\hline 0.9 & FDI & $-0.725^{*}$ & -0.577 & $-0.236^{* *}$ & $-0.591^{* *+*}$ & $-0.364^{*}$ & $0.499^{+\ldots+*}$ & 0.100 & $-0.923^{\text {t*x }}$ & -0.250 & $-0.730^{* * *}$ & -0.180 & -0.160 & 0.294 & -0.061 & $-0.710^{* * * *}$ & $-0.652^{2+*+}$ \\
\hline 0.9 & $\mathrm{FDI}$ & $(0.401)$ & $(0.392)$ & $(0.120)$ & $(0.166)$ & $(0.204)$ & $(0.088)$ & $(0.147)$ & $(0.289)$ & $(0.428)$ & $(0.253)$ & $(0.177)$ & $(0.165)$ & $(0.199)$ & $(0.259)$ & $(0.223)$ & $(0.120)$ \\
\hline & Other Capital Flows & -0.925 & -0.521 & -0.031 & $0.576^{\text {** }}$ & 0.300 & $0.444^{*+* x}$ & $1.316^{* *}$ & $-0.797^{*}$ & 0.611 & $1.365^{\text {ton }}$ & -0.460 & 0.112 & 0.144 & -0.042 & $0.841^{* *}$ & $0.820^{*}$ \\
\hline & & $(0.609)$ & $(0.847)$ & $(0.321)$ & $(0.281)$ & $(0.215)$ & $(0.159)$ & $(0.634)$ & $(0.422)$ & $(0.624)$ & $(0.427)$ & $(0.295)$ & $(0.364)$ & $(0.238)$ & $(0.222)$ & $(0.417)$ & $(0.423)$ \\
\hline & Oil & -0.004 & $\begin{array}{l}-0.065 \\
-0.064)\end{array}$ & -0.021 & $\begin{array}{l}-0.041^{* * *} \\
(0.015)\end{array}$ & $\begin{array}{l}-0.045^{* \star * *} \\
0.012)\end{array}$ & $\begin{array}{l}-0.020 \\
-0.013)\end{array}$ & 0.007 & $\begin{array}{l}-0.112^{* *} \\
(0.045\end{array}$ & $\begin{array}{l}-0.008 \\
-0.036\end{array}$ & $\begin{array}{l}-0.034 \\
-0.031\end{array}$ & $\begin{array}{l}-0.055 \\
-0.037\end{array}$ & $\begin{array}{r}-0.036 \\
0.033)\end{array}$ & $\begin{array}{r}-0.009 \\
-0.018\end{array}$ & $\begin{array}{l}0.007 \\
0.017\end{array}$ & $\begin{array}{l}-0.002 \\
(0.019)\end{array}$ & $\begin{array}{c}-0.057^{\star} \\
(0.030\end{array}$ \\
\hline & Uil & $(0.062)$ & $(0.064)$ & $(0.017)$ & $(0.015)$ & $(0.012)$ & $(0.013)$ & $(0.020)$ & $(0.045)$ & $(0.036)$ & $(0.031)$ & $(0.037)$ & $(0.033)$ & $(0.018)$ & $(0.017)$ & $(0.019)$ & $(0.030)$ \\
\hline & Intercept & $0.200^{*+*+*}$ & $0.299^{\text {tat* }}$ & $0.090^{*+* x+}$ & $0.172^{* * * *}$ & $0.066^{*+* x}$ & $0.054^{* * * *}$ & $0.059^{+\ldots+*}$ & -0.003 & $0.110^{* *}$ & $0.215^{\text {tow }}$ & $0.181^{*+*}$ & $0.058^{*+*+}$ & $0.118^{*+\alpha}$ & 0.033 & $0.132^{+*+*}$ & $0.142^{2+*+}$ \\
\hline & & $(0.054)$ & $(0.059)$ & $(0.018)$ & $(0.024)$ & $(0.012)$ & $(0.012)$ & $(0.013)$ & $(0.032)$ & $(0.047)$ & $(0.032)$ & $(0.027)$ & $(0.015)$ & $(0.026)$ & $(0.033)$ & $(0.027)$ & $(0.018)$ \\
\hline & AR & $0.958^{* *}$ & $0.739^{* \star *}$ & $0.987^{*+*+*}$ & $0.427^{*}$ & $1.168^{+* x+}$ & $0.344^{* *}$ & $1.098^{t+* x}$ & $0.50^{+* * *}$ & $0.296^{* * *+}$ & $0.648^{+4+4}$ & $0.363^{* *}$ & $0.849^{*+* * *}$ & $0.760^{m+* *+}$ & -0.011 & $0.311^{*}$ & $0.703^{* * * x}$ \\
\hline
\end{tabular}

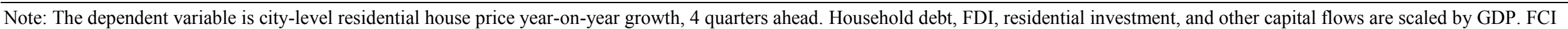

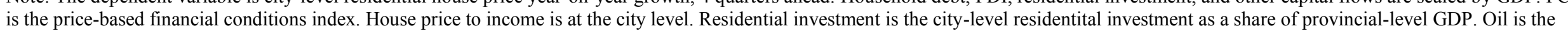

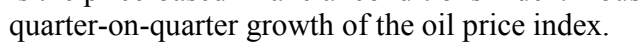


$\square \square$

Annex Table 3. United States: Long-term City-level Coefficients

\begin{tabular}{|c|c|c|c|c|c|c|c|c|c|c|c|c|c|c|c|c|c|c|c|c|c|c|c|c|}
\hline Tau & Variable & Atlanta & Boston & Charlotte & Chicago & Cleveland & Dallas & Denver & Detroit & Houston & Las Vegas & $\begin{array}{l}\text { Los } \\
\text { Angeles }\end{array}$ & Miami & Minneapolis & New York & Philadelphia & Phoenix & Portland & San Diego & $\begin{array}{c}\text { San } \\
\text { Francisco }\end{array}$ & Seattle & Tampa & $\begin{array}{c}\text { Washington } \\
\mathrm{DC}\end{array}$ & $\begin{array}{l}\text { United } \\
\text { States }\end{array}$ \\
\hline \multirow{17}{*}{0.1} & \multirow[b]{2}{*}{ House Price-to-Income } & $0.138^{\mathrm{tan}}$ & -0.016 & $0.061^{*}$ & 0.024 & $0.057^{* \mathrm{~mm}}$ & $0.048^{*}$ & $0.038^{\text {** }}$ & 0.038 & -0.001 & $\begin{array}{c}-0.028 \\
-12\end{array}$ & $0.094^{* *}$ & 0.056 & 0.015 & -0.014 & -0.007 & -0.015 & 0.028 & $0.085^{\text {wn+ }}$ & $0.172^{2+*+}$ & 0.016 & -0.009 & -0.002 & 0.023 \\
\hline & & $(0.035)$ & $(0.021)$ & $(0.034)$ & $(0.030)$ & $(0.018)$ & $(0.028)$ & $(0.018)$ & $(0.027)$ & $(0.023)$ & $(0.037)$ & $(0.043)$ & $(0.056)$ & & $(0.014)$ & & $(0.028)$ & & & $(0.025)$ & $(0.0$ & & & \\
\hline & \multirow{2}{*}{ Housing Starts } & -0.447 & $0.656{ }^{* *}$ & -0.355 & -0.080 & -0.206 & -0.154 & -0.572 & -0.056 & $-0.983^{+* m}$ & $1.512^{*}$ & 0.297 & -0.325 & -0.171 & $0.896^{\mathrm{m} * m}$ & -0.162 & $-1.218^{* * m}$ & 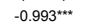 & $-0.484^{*}$ & 0.282 & $-0.827 \cdots$ & 0.231 & -0.099 & -0.029 \\
\hline & & $(0.005)$ & $(0.003)$ & $(0.004)$ & $(0.003)$ & $(0.003)$ & $(0.002)$ & $(0.004)$ & $(0.005)$ & $(0.003)$ & $(0.009)$ & $(0.005)$ & $(0.004)$ & $(0.003)$ & $(0.003)$ & $(0.003)$ & $(0.004)$ & $(0.003)$ & $(0.003)$ & $(0.007)$ & $(0.003)$ & $(0.005)$ & $(0.002)$ & $(0.003)$ \\
\hline & \multirow{2}{*}{$\mathrm{FCl}$} & 0.007 & 0.008 & 0.003 & 0.009 & -0.004 & -0.017 & -0.017 & 0.009 & $-0.030^{+m+m}$ & -0.004 & 0.019 & -0.004 & 0.010 & 0.011 & -0.001 & $-0.046^{m+m}$ & $-0.022^{* \prime}$ & -0.003 & $-0.039^{+2 n+4}$ & $-0.044^{6 \cdots+m}$ & 0.006 & -0.002 & -0.008 \\
\hline & & $(0.019)$ & $(0.010)$ & $(0.019)$ & $(0.010)$ & $(0.009)$ & $(0.011)$ & $(0.015)$ & $(0.010)$ & $(0.011)$ & $(0.041)$ & $(0.019)$ & $(0.022)$ & $(0.012)$ & $(0.011)$ & $(0.014)$ & $(0.016)$ & $(0.010)$ & $(0.012)$ & $(0.012)$ & $(0.012)$ & $(0.035)$ & $(0.014)$ & $(0.016)$ \\
\hline & \multirow{2}{*}{ Household Debt } & $-0.014^{\prime * m}$ & 0.001 & $-0.008^{* * *}$ & -0.006 & $-0.011^{x+m}$ & $-0.011^{\prime * m}$ & $-0.007^{* *}$ & $-0.019^{+\cdots+}$ & -0.001 & -0.002 & -0.005 & -0.004 & -0.007 & -0.002 & $-0.006^{n+*+4}$ & -0.003 & -0.005 & $0.010^{\cdots \cdots}$ & $-0.011^{* * *}$ & -0.008 & -0.004 & -0.003 & $0.006^{\cdots+m}$ \\
\hline & & $(0.003)$ & $(0.003)$ & $(0.003)$ & $(0.004)$ & $(0.003)$ & $(0.002)$ & $(0.003)$ & $(0.004)$ & $(0.002)$ & $(0.007)$ & $(0.004)$ & $(0.005)$ & $(0.004)$ & $(0.002)$ & $(0.002)$ & $(0.004)$ & $(0.004)$ & $(0.003)$ & $(0.004)$ & $(0.005)$ & $(0.006)$ & $(0.002)$ & $(0.002)$ \\
\hline & \multirow{2}{*}{ FDI } & 0.450 & -0.594 & $-4.709^{\circ}$ & $-5.188^{t+m+*}$ & 0.566 & -0.531 & -0.476 & $-6.657^{* *}$ & -0.418 & $-14.484^{\prime \cdots m}$ & 0.624 & $2.570^{\prime * m+*}$ & $-5.456^{\mathrm{ntm}}$ & $-0.771^{*}$ & -2.388 & $-3.974^{* *}$ & -1.106 & $2.438^{\prime *}$ & $4.079^{\cdots \cdots}$ & -0.182 & $-7.452^{* *}$ & -0.034 & $-4.111^{\prime \prime \prime}$ \\
\hline & & $(0.015)$ & $(0.006)$ & $(0.025)$ & $(0.016)$ & $(0.013)$ & $(0.015)$ & $(0.006)$ & $(0.027)$ & $(0.008)$ & $(0.037)$ & $(0.017)$ & $(0.009)$ & $(0.015)$ & $(0.005)$ & $(0.017)$ & $(0.018)$ & $(0.010)$ & $(0.007)$ & $(0.007)$ & $(0.011)$ & $(0.032)$ & $(0.010)$ & $(0.013)$ \\
\hline & \multirow{2}{*}{ Other Capital Flows } & 0.028 & 0.030 & 0.033 & 0.037 & 0.022 & 0.014 & 0.007 & -0.003 & -0.035 & 0.064 & $0.090^{* *}$ & 0.015 & 0.032 & $0.040^{\circ}$ & 0.023 & -0.009 & 0.019 & 0.030 & -0.049 & -0.030 & 0.003 & 0.010 & -0.011 \\
\hline & & $(0.031)$ & $(0.030)$ & $(0.034)$ & $(0.026)$ & $(0.023)$ & $(0.023)$ & $(0.023)$ & $(0.043)$ & $(0.029)$ & $(0.071)$ & $(0.043)$ & $(0.052)$ & $(0.022)$ & $(0.024)$ & $(0.035)$ & $(0.022)$ & $(0.025)$ & $(0.026)$ & $(0.039)$ & $(0.035)$ & $(0.038)$ & $(0.044)$ & $(0.024)$ \\
\hline & Oil & $(0.060)$ & $(0.046)$ & $(0.106)$ & $(0.061)$ & $(0.046)$ & $(0.052)$ & $(0.058)$ & $(0.081)$ & $(0.056)$ & $(0.112)$ & $(0.057)$ & $(0.060)$ & $(0.078)$ & $(0.026)$ & $(0.059)$ & $(0.092)$ & $(0.040)$ & $(0.031)$ & $(0.060)$ & $(0.052)$ & $(0.108)$ & $(0.065)$ & (0.032) \\
\hline & \multirow{2}{*}{ Intercept } & 0.014 & $-0.262^{2 \text { tot }}$ & -0.103 & $-0.121^{m+* x}$ & 0.035 & $-0.0599^{* *}$ & $-0.109^{* *}$ & -0.032 & $-0.098^{+*+4}$ & $-0.497^{+\cdots+4}$ & $-0.239^{+* n+4}$ & $-0.309^{+*+4}$ & $-0.138^{t+4}$ & $-0.247^{*+\cdots+4}$ & $-0.137^{70+0+}$ & $-0.237^{7+\cdots+*}$ & $-0.217^{7+n+x}$ & $-0.318^{t+4}$ & $-0.137^{7+\ldots+k}$ & $-0.160^{* *+*}$ & $-0.331^{1+x+x}$ & $-0.274^{t+n+x}$ & $-0.431^{\prime \prime \cdots}$ \\
\hline & & $(0.033)$ & $(0.027)$ & $(0.063)$ & $(0.044)$ & $(0.026)$ & $(0.024)$ & $(0.043)$ & $(0.051)$ & $(0.032)$ & $(0.105)$ & $(0.032)$ & $(0.038)$ & $(0.044)$ & $(0.014)$ & $(0.029)$ & $(0.063)$ & $(0.030)$ & $(0.021)$ & $(0.042)$ & $(0.041)$ & $(0.058)$ & $(0.036)$ & $(0.029)$ \\
\hline & \multirow{2}{*}{$A R$} & $0.178^{* \prime}$ & $0.299^{\prime \prime *}$ & $0.224^{*}$ & 0.187 & $0.522^{n+m+4}$ & 0.180 & $0.252^{*}$ & $0.247^{*}$ & 0.025 & 0.028 & 0.000 & -0.042 & $0.281^{*}$ & $0.128^{* \prime \prime}$ & $0.234^{*+\ldots+}$ & $-0.221^{* *+*}$ & -0.010 & -0.019 & $-0.256^{t+m+\infty}$ & -0.118 & 0.016 & 0.065 & $-0.184^{* *}$ \\
\hline & & $(0.082)$ & $(0.051)$ & $(0.114)$ & $(0.124)$ & $(0.142)$ & $(0.205)$ & $(0.132)$ & $(0.143)$ & $(0.175)$ & $(0.099)$ & $(0.063)$ & $(0.135)$ & $(0.131)$ & $(0.060)$ & $(0.067)$ & $(0.061)$ & $(0.099)$ & $(0.053)$ & $(0.067)$ & $(0.121)$ & $(0.111)$ & $(0.054)$ & $(0.078)$ \\
\hline & & $0.124^{\prime \cdots m}$ & -0.008 & $0.078^{\text {tont }}$ & $0.046^{*}$ & $0.081^{\text {tow }}$ & 0.028 & $0.043^{* *-m}$ & $0.098^{+\mathrm{mat}}$ & 0.014 & 0.042 & $0.118^{\text {twat }}$ & $0.080^{*}$ & 0.017 & 0.004 & 0.009 & -0.020 & 0.003 & $0.064^{4 *}$ & $0.163^{3 * m}$ & 0.025 & $0.054^{*}$ & 0.038 & 0.021 \\
\hline & House Price-to-Income & $(0.024)$ & $(0.014)$ & $(0.024)$ & $(0.024)$ & $(0.013)$ & $(0.025)$ & $(0.014)$ & $(0.026)$ & $(0.021)$ & $(0.034)$ & $(0.020)$ & $(0.047)$ & $(0.018)$ & $(0.017)$ & $(0.020)$ & $(0.041)$ & $(0.024)$ & $(0.029)$ & $(0.022)$ & $(0.019)$ & $(0.025)$ & $(0.033)$ & $(0.039)$ \\
\hline & & 0.093 & $0.483^{* *}$ & $-0.441^{\cdots \cdots}$ & 0.104 & -0.309 & -0.146 & -0.215 & 0.029 & $-0.514^{\cdots+\cdots}$ & $1.278^{* *}$ & -0.378 & -0.181 & 0.174 & $0.823^{n+\cdots}$ & -0.051 & $-1.376^{* \ldots+\cdots}$ & -0.472 & 0.022 & -0.145 & $-0.7399^{* \prime}$ & -0.086 & 0.329 & -0.161 \\
\hline & Housing Starts & $(0.002)$ & $(0.002)$ & $(0.001)$ & $(0.003)$ & $(0.002)$ & $(0.001)$ & $(0.002)$ & $(0.004)$ & $(0.002)$ & $(0.006)$ & $(0.004)$ & $(0.003)$ & $(0.003)$ & $(0.002)$ & $(0.002)$ & $(0.003)$ & $(0.003)$ & $(0.003)$ & $(0.005)$ & $(0.004)$ & $(0.002)$ & $(0.003)$ & $(0.002)$ \\
\hline & $F C$ & 0.002 & 0.012 & $-0.017^{*}$ & 0.012 & -0.001 & $-0.022^{* *}$ & -0.012 & 0.009 & $-0.018^{* *+}$ & 0.026 & 0.006 & -0.008 & 0.000 & $0.026^{* *}$ & 0.005 & 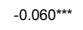 & $-0.043^{+\ldots+m}$ & -0.006 & $-0.034^{* * *}$ & $-0.038^{* *+*}$ & 0.005 & 0.018 & -0.018 \\
\hline & $\mathrm{FCl}$ & $(0.018)$ & $(0.012)$ & $(0.010)$ & $(0.009)$ & $(0.006)$ & $(0.010)$ & $(0.011)$ & $(0.013)$ & $(0.008)$ & $(0.023)$ & $(0.016)$ & $(0.023)$ & $(0.012)$ & $(0.010)$ & $(0.011)$ & $(0.019)$ & $(0.015)$ & $(0.015)$ & $(0.015)$ & $(0.012)$ & $(0.015)$ & $(0.016)$ & $(0.014)$ \\
\hline & & $-0.013^{\text {wat }}$ & 0.004 & $-0.005^{+* * *}$ & -0.000 & $-0.005^{\text {tom }}$ & $-0.007^{+\cdots+n}$ & $-0.011^{\text {tom }}$ & $-0.019^{+m+\infty}$ & -0.001 & 0.002 & 0.002 & -0.002 & $-0.0066^{* \prime}$ & -0.000 & -0.002 & -0.003 & $-0.008^{* *}$ & $0.007^{* *}$ & $-0.006^{* *+}$ & -0.001 & 0.003 & 0.003 & $0.004^{*}$ \\
\hline & Household Debt & $(0.003)$ & $(0.003)$ & $(0.002)$ & $(0.003)$ & $(0.001)$ & $(0.001)$ & $(0.002)$ & $(0.004)$ & $(0.002)$ & $(0.004)$ & $(0.005)$ & $(0.004)$ & $(0.003)$ & $(0.002)$ & $(0.002)$ & $(0.006)$ & $(0.003)$ & $(0.003)$ & $(0.003)$ & $(0.004)$ & $(0.003)$ & $(0.002)$ & $(0.002)$ \\
\hline 0.5 & $F D \mid$ & 0.594 & -0.815 & -0.203 & $-3.714^{* *}$ & 0.669 & -0.234 & -0.404 & -1.123 & 0.099 & $-8.956^{* * *}$ & 1.456 & $2.543^{\text {twn }}$ & $-3.313^{*}$ & $-1.000^{*}$ & -1.211 & -2.016 & -1.294 & $1.837^{* *}$ & $2.968^{* \cdots+\cdots}$ & 1.269 & -0.479 & -1.288 & $-1.358^{*}$ \\
\hline & Other Capital Flows & $(0.033)$ & $(0.023)$ & $(0.014)$ & $(0.018)$ & $(0.011)$ & $(0.021)$ & $(0.023)$ & $(0.023)$ & $(0.021)$ & $(0.050)$ & $(0.055)$ & $(0.036)$ & $(0.020)$ & $(0.021)$ & $(0.024)$ & $(0.030)$ & $(0.028)$ & $(0.028)$ & $(0.040)$ & $(0.035)$ & $(0.031)$ & $(0.039)$ & $(0.023)$ \\
\hline & Oil & -0.006 & $0.4666^{* \cdots}$ & $0.060^{*}$ & $0.275^{m+x}$ & -0.012 & $0.089^{\text {tant }}$ & $0.124^{*+*}$ & -0.034 & $0.156^{\mathrm{men}}$ & $0.450^{+3 *}$ & $0.262^{t+4+}$ & $0.278^{*+* x}$ & $0.201^{1 *}$ & $0.415^{\text {tant }}$ & $0.257^{\mathrm{knt}}$ & $0.280^{+5 *}$ & $0.273^{*+\cdots}$ & $0.369^{m+*}$ & $0.176^{\text {ton }}$ & $0.273^{+\ldots+m}$ & $0.345^{\text {tat }}$ & $0.464^{+\cdots+1}$ & $0.376^{\mathrm{mat}}$ \\
\hline & Oil & $(0.051)$ & $(0.062)$ & $(0.032)$ & $(0.055)$ & $(0.024)$ & $(0.028)$ & $(0.045)$ & $(0.054)$ & $(0.036)$ & $(0.089)$ & $(0.060)$ & $(0.073)$ & $(0.079)$ & $(0.033)$ & $(0.049)$ & $(0.099)$ & $(0.035)$ & $(0.040)$ & $(0.042)$ & $(0.047)$ & $(0.058)$ & $(0.053)$ & $(0.060)$ \\
\hline & Intercept & 0.000 & $-0.285^{+\cdots *+}$ & $-0.040^{*}$ & $-0.179^{+* *+*}$ & 0.001 & $-0.060^{+0 *+\infty}$ & $-0.086^{+* *+*}$ & 0.054 & $-0.10^{+\cdots *}$ & $-0.373^{\text {tont }}$ & $-0.197^{7 * *}$ & $-0.209^{+* n+x}$ & $-0.108^{+* * *}$ & $-0.260^{+* * *}$ & $-0.162^{2 * n+m}$ & $-0.204^{4 * m}$ & $-0.201^{n+m}$ & $-0.287^{* \mathrm{cot}}$ & $-0.139^{+m+x}$ & $-0.214^{* \ldots+x}$ & $-0.225^{+* x}$ & $-0.295^{\mathrm{m*}}$ & $-0.328^{+\cdots+}$ \\
\hline & Intercept & $(0.030)$ & $(0.036)$ & $(0.022)$ & $(0.032)$ & $(0.017)$ & $(0.014)$ & $(0.032)$ & $(0.040)$ & $(0.021)$ & $(0.057)$ & $(0.032)$ & $(0.048)$ & $(0.041)$ & $(0.019)$ & $(0.028)$ & $(0.078)$ & $(0.023)$ & $(0.023)$ & $(0.027)$ & $(0.036)$ & $(0.039)$ & $(0.029)$ & $(0.055)$ \\
\hline & & 0.195 & $0.243^{\text {mw }}$ & $0.203^{\text {"w }}$ & 0.098 & $0.533^{+\ldots+n}$ & 0.091 & $0.191^{\text {wm }}$ & $0.227^{* *}$ & -0.113 & 0.018 & -0.048 & -0.083 & 0.235 & $0.117^{7 *}$ & $0.143^{* * *}$ & $-0.243^{+m+x}$ & -0.092 & 0.016 & $-0.275^{\text {tax }}$ & $-0.240^{m *}$ & 0.099 & 0.058 & -0.072 \\
\hline & $A R$ & $(0.122)$ & $(0.056)$ & $(0.090)$ & $(0.086)$ & $(0.074)$ & $(0.122)$ & $(0.073)$ & $(0.101)$ & $(0.096)$ & $(0.059)$ & $(0.055)$ & $(0.135)$ & $(0.148)$ & $(0.055)$ & $(0.064)$ & $(0.073)$ & $(0.108)$ & $(0.078)$ & $(0.060)$ & $(0.119)$ & $(0.106)$ & $(0.069)$ & $(0.121)$ \\
\hline & & $0.082^{2+*}$ & $-0.025^{*}$ & $0.069^{\mathrm{man}}$ & $0.080^{+* *+}$ & $0.037^{7 *}$ & $\begin{array}{l}0.038 \\
\end{array}$ & $0.026^{\mathrm{tat}}$ & $0.096^{\text {twat }}$ & 0.010 & \begin{tabular}{l|l|}
0.025 \\
\end{tabular} & $0.079^{\text {tonte }}$ & $0.102^{*+4 t}$ & $0.039^{*}$ & -0.001 & -0.001 & $\begin{array}{l}0.006 \\
\end{array}$ & $-0.026^{* *}$ & $0.087^{7+m+1}$ & $0.110^{m+m}$ & 0.007 & $0.061^{1 *}$ & $\begin{array}{l}0.022 \\
\end{array}$ & $\begin{array}{l}0.028 \\
\end{array}$ \\
\hline & House Price--to-Income & $(0.015)$ & $(0.015)$ & $(0.019)$ & $(0.028)$ & $(0.016)$ & $(0.025)$ & $(0.009)$ & $(0.012)$ & $(0.025)$ & $(0.017)$ & $(0.019)$ & $(0.033)$ & $(0.022)$ & $(0.021)$ & $(0.021)$ & $(0.035)$ & $(0.013)$ & $(0.014)$ & $(0.028)$ & $(0.028)$ & & & $(0.040)$ \\
\hline & & 0.017 & $0.6077^{*}$ & $-0.436^{* *}$ & 0.0 & -0.052 & -0.299 & -0.4 & -0.094 & -0.175 & -0.084 & 0.5 & -0.023 & 0.49 & 0.61 & -0.3 & $-1.131 \ldots+\cdots$ & -0.79 & 0.2 & -0.6 & $-0.547^{*}$ & & 0.4 & $-0.445^{*}$ \\
\hline & Housing Starts & $(0.002)$ & $(0.003)$ & $(0.002)$ & $(0.0$ & $(0.002)$ & $(0.002)$ & $(0.0$ & $(0.00$ & $(0.003)$ & $(0.0$ & $(0.0$ & $(0.002)$ & $(0.0)$ & $(0.0$ & $(0.0)$ & $(0.003)$ & $(0.0$ & $(0.0$ & & $(0.0)$ & & & $(0.003)$ \\
\hline & $\mathrm{FCl}$ & $-0.030^{*-}$ & $0.020^{\circ *}$ & $-0.019^{* * *}$ & 0.016 & 0.001 & $-0.031^{1+* *}$ & $-0.041^{* * * *}$ & 0.015 & -0.018 & 0.0 & 0.0 & 0.001 & 0.003 & 0.02 & 0.028 & $-0.044^{*}$ & -0.05 & 0.00 & -0. & -0.04 & 0.0 & 0.0 & 0.0 \\
\hline & $\mathrm{FCl}$ & $(0.014)$ & $(0.009)$ & $(0.008)$ & $(0.016)$ & & $(0.009)$ & $(0.007)$ & $(0.015)$ & $(0.012)$ & & $(0.0$ & $(0.022)$ & & $(0.0$ & & & $(0 . c$ & $(0.0$ & & $(0.0$ & & $(0.0$ & $(0.015)$ \\
\hline & Household Debt & $-0.013^{\mathrm{mat}}$ & $0.004^{4 *}$ & $-0.004^{-4 *}$ & 0.0 & -0.00 & $-0.008^{+* * *}$ & -0.00 & $-0.019^{\text {tow }}$ & -0.002 & 0.0 & 0.0 & 0.002 & $-0.0 \mathrm{c}$ & 0.0 & 0.00 & 0.00 & -0.00 & 0.00 & -0. & -0.0 & & 0.00 & $0.008^{\text {"w* }}$ \\
\hline & Housenold Debt & $(0.002)$ & $(0.002)$ & $(0.001)$ & $(0.0$ & & $(0.001)$ & $(0.0)$ & $(0.003)$ & $(0.00)$ & & $(0.00)$ & $(0.003)$ & $(0.0$ & $(0.0$ & $(0.00)$ & $(0.00)$ & $(0.0$ & $(0.0$ & & $(0.0$ & & $(0.0$ & $(0.001)$ \\
\hline 0.9 & FDI & 0.389 & -0.717 & -0.7 & -0.7 & & -0.4 & 0. & -1.00 & -0.3 & & 0.3 & 3.09 & & -0. & & -0.6 & & 1.57 & 2.7 & 0.7 & & & -0.9 \\
\hline 0.9 & $\mathrm{FDI}$ & $(0.00$ & $(0.0$ & $(0.0$ & $(0.0$ & & $(0.0$ & $(0.0)$ & $(0.0$ & $(0 . c$ & & 10.8 & $(0.0$ & & $(0.0$ & & $(0.0)$ & $(0 . c$ & $(0.0$ & & $(0.0$ & & & $(0.0$ \\
\hline & Other Capital Flows & 0.0 & 0.05 & 0.0 & 0.0 & & & & & & & & & & & & & & & & & & & \\
\hline & Other Capital Flows & $(0.025)$ & $(0.032)$ & $(0.010)$ & $(0.0)$ & $(0.4$ & $(0.018)$ & & $(0.030)$ & $(0.0)$ & & $(0 . c$ & & $(0.02$ & $(0.0$ & $(0.0)$ & $(0.026)$ & $(0.0)$ & $(0.0)$ & $(0.4$ & $(0.0)$ & $(0)$. & $(0.6$ & $(0.014)$ \\
\hline & Oil & -0.020 & $0.482^{2 * \cdots}$ & $0.077^{* *}$ & $0.239^{\mathrm{m} m}$ & & $0.111^{1+* * *}$ & & -0.0 & 0.13 & & & & & & & & & & & & & $0.4 c$ & $0.396^{\mathrm{wat}}$ \\
\hline & OII & $(0.030)$ & $(0.029)$ & $(0.035)$ & $(0.066)$ & $(0.0$ & $(0.023)$ & $(0.033)$ & $(0.028)$ & $(0.04$ & & $(0.07$ & $(0.043)$ & & $(0.0$ & $(0 . c$ & $(0.098)$ & $(0.025)$ & $(0.0$ & $(0.0$ & $(0.061)$ & $(0.063)$ & $(0.049)$ & $(0.061)$ \\
\hline & Intercept & 0.023 & $-0.282^{2 * * *}$ & $\begin{array}{l}-0.042^{*} \\
0.025)\end{array}$ & $-0.161+\cdots x$ & 0.03 & $-0.0611^{* w * *}$ & -0.09 & $0.088^{* * * *}$ & -0.078 & -0.2 & -0.24 & $-0.141+\cdots *$ & -0.0 & -0.25 & -0.1 & $-0.209+\cdots$ & -0.1 & -0.27 & -0.21 & $-0.175^{* \cdots * *}$ & -0.15 & $-0.249^{*+\cdots * *}$ & $-0.314+\cdots$ \\
\hline & & & $(0.015)$ & $\begin{array}{l}(0.025) \\
0.1833^{*}\end{array}$ & $(0.042)$ & $\begin{array}{l}(0.016) \\
0411+\cdots\end{array}$ & (0.015) & & $\begin{array}{l}(0.025) \\
0.1797 \ldots\end{array}$ & $(0.027)$ & & & & & $(0.0)$ & & & & $(0.028)$ & & $(0.046)$ & $(0.040)$ & $(0.030)$ & $(0.042)$ \\
\hline & AR & $\begin{array}{l}0.106 \\
(0.093)\end{array}$ & $\begin{array}{l}0.290^{0+*} \\
(0.0677)\end{array}$ & $\begin{array}{l}0.183^{*} \\
(0.099)\end{array}$ & $\begin{array}{l}0.137 \\
(0.157)\end{array}$ & $\begin{array}{l}0.411+1+1 \\
(0.096)\end{array}$ & 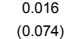 & 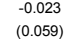 & $\begin{array}{l}0.197 * 0 ; \\
(0.054)\end{array}$ & 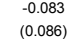 & $\begin{array}{l}-0.058 \\
(0.053)\end{array}$ & 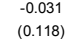 & $\begin{array}{l}-0.042 \\
(0.1177)\end{array}$ & $\begin{array}{l}0.390^{\circ}+* \\
(0.149)\end{array}$ & $\begin{array}{l}0.133{ }^{*} \\
(0.061)\end{array}$ & $\begin{array}{l}0.164^{* *} \\
(0.072)\end{array}$ & $\begin{array}{r}-0.1150 \\
(0.115)\end{array}$ & $\begin{array}{l}-0.084 \\
-0.078)\end{array}$ & $\begin{array}{l}-0.073 \\
(0.0899)\end{array}$ & $\begin{array}{l}-0.231^{-3 * 4} \\
(0.055)\end{array}$ & $\begin{array}{r}-0.108 \\
(0.0833\end{array}$ & $\begin{array}{l}0.196^{* * *} \\
0.8066\end{array}$ & $\begin{array}{l}0.069 \\
(0.104)\end{array}$ & $\begin{array}{c}0.068 \\
(0.050)\end{array}$ \\
\hline
\end{tabular}

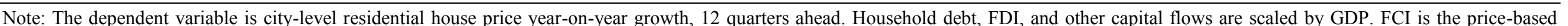

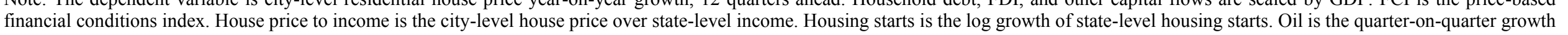

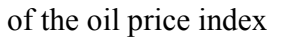


$\square \square$

Annex Table 4. Canada: Long-term City-level Coefficients

\begin{tabular}{|c|c|c|c|c|c|c|c|c|c|c|c|c|c|c|c|c|c|}
\hline Tau & Variable & Calgary & Edmonton & Ham ilton & London & Montreal & Quebec City & Regina & Toronto & Vancouver & Victoria & Windsor & Winnipeg & Ottawa & $\begin{array}{l}\text { Greater } \\
\text { Sudbury }\end{array}$ & $\begin{array}{c}\text { St. } \\
\text { Catharines } \\
\end{array}$ & Canada \\
\hline \multirow{18}{*}{0.1} & \multirow[b]{2}{*}{ House Price-to-Income } & $-0.540^{*+* *}$ & $-0.586^{\text {tot+t }}$ & 0.008 & $-0.499^{+*+*}$ & $\begin{array}{l}-0.092 \\
\end{array}$ & $-0.271^{4+*}$ & $-0.075^{\text {t* }}$ & -0.304 & $-0.150^{*}$ & 0.040 & -0.155 & 0.011 & $-0.199^{*+*}$ & -0.043 & $-0.214^{*}$ & $-1.415^{\text {tat }}$ \\
\hline & & $(0.076)$ & $(0.066)$ & $(0.038)$ & $(0.091)$ & $(0.075)$ & $(0.026)$ & $(0.032)$ & $(0.289)$ & $(0.083)$ & $(0.075)$ & $(0.103)$ & $(0.046)$ & $(0.052)$ & $(0.044)$ & $(0.113)$ & $(0.156)$ \\
\hline & \multirow{2}{*}{ Residential Investment } & -6.398 & $-13.148^{*}$ & $-18.466^{* *}$ & 5.450 & 10.313 & $21.079^{*+* x}$ & $-15.972^{*+4 x}$ & -10.124 & $-24.322^{* * * *}$ & $-32.999^{*+* x}$ & -4.408 & -6.439 & $9.325^{* *}$ & $10.901^{* *}$ & -6.174 & $48.930^{t+x+4}$ \\
\hline & & $(4.438)$ & $(7.252)$ & $(8.755)$ & $(5.268)$ & (10.626) & $(4.064)$ & $(4.104)$ & $(12.320)$ & $(4.062)$ & $(5.369)$ & $(6.031)$ & $(4.889)$ & $(4.223)$ & $(4.703)$ & (10.717) & (5.727) \\
\hline & \multirow{2}{*}{$\mathrm{FCl}$} & $-0.077^{*+* *}$ & -0.028 & $-0.103^{* *}$ & -0.031 & -0.030 & $-0.080^{* * *}$ & -0.002 & $-0.166^{* * *+}$ & 0.020 & 0.042 & 0.011 & $-0.047^{*}$ & $-0.107^{* \star *}$ & -0.044 & $-0.120^{* * *}$ & $-0.067^{7+n+x}$ \\
\hline & & $(0.024)$ & $(0.031)$ & $(0.042)$ & $(0.029)$ & $(0.037)$ & $(0.026)$ & $(0.020)$ & $(0.047)$ & $(0.029)$ & $(0.038)$ & $(0.014)$ & $(0.026)$ & $(0.034)$ & $(0.027)$ & $(0.034)$ & $(0.019)$ \\
\hline & \multirow{2}{*}{ Household Debt } & 0.001 & $0.014^{*+\alpha+x}$ & $-0.024^{* * *}$ & 0.000 & -0.004 & $-0.008^{t+x}$ & $0.006^{*}$ & -0.005 & 0.008 & -0.001 & $-0.011^{* * *}$ & 0.002 & 0.001 & 0.002 & $-0.024^{* * *}$ & $0.007^{*}$ \\
\hline & & $(0.003)$ & $(0.004)$ & $(0.005)$ & $(0.004)$ & $(0.005)$ & $(0.002)$ & $(0.003)$ & $(0.009)$ & $(0.006)$ & $(0.006)$ & $(0.002)$ & $(0.003)$ & $(0.003)$ & $(0.004)$ & $(0.005)$ & $(0.003)$ \\
\hline & \multirow{2}{*}{ FDI } & $1.553^{\text {tat }}$ & $1.359^{t+2+}$ & $1.649^{+40+x}$ & -0.207 & $1.572^{\star \star *}$ & $2.506^{4+x+x}$ & 0.366 & $2.143^{+4+x}$ & $1.126^{+2+x}$ & 0.388 & -0.294 & $1.072^{* * * *}$ & $1.642^{t+4 x}$ & 0.153 & $0.774^{+k+x}$ & $-1.446^{* *}$ \\
\hline & & $(0.226)$ & $(0.489)$ & $(0.291)$ & $(0.439)$ & $(0.644)$ & $(0.156)$ & $(0.506)$ & $(0.323)$ & $(0.388)$ & $(0.750)$ & $(0.242)$ & $(0.314)$ & $(0.369)$ & $(0.334)$ & $(0.287)$ & $(0.564)$ \\
\hline & \multirow{2}{*}{ Other Capital Flows } & 0.591 & 0.326 & $-1.312^{*+* x}$ & 0.393 & -0.210 & 0.291 & 0.491 & 0.454 & 0.448 & -0.523 & 0.279 & -0.051 & 0.615 & $-0.709^{* *}$ & 0.458 & 0.148 \\
\hline & & $(0.388)$ & $(0.408)$ & $(0.504)$ & $(0.240)$ & $(0.482)$ & $(0.325)$ & $(0.444)$ & $(0.526)$ & $(0.363)$ & $(0.426)$ & $(0.331)$ & $(0.281)$ & $(0.441)$ & $(0.322)$ & $(0.316)$ & (0.313) \\
\hline & \multirow{2}{*}{ Oil } & -0.008 & 0.061 & -0.022 & -0.001 & -0.016 & $-0.060^{*+*}$ & 0.017 & -0.005 & 0.021 & 0.044 & 0.009 & $-0.086^{* *}$ & -0.061 & -0.056 & -0.040 & -0.038 \\
\hline & & $(0.021)$ & $(0.056)$ & $(0.052)$ & $(0.030)$ & $(0.049)$ & $(0.029)$ & $(0.021)$ & $(0.058)$ & $(0.070)$ & $(0.056)$ & $(0.025)$ & $(0.039)$ & $(0.043)$ & $(0.037)$ & $(0.055)$ & $(0.035)$ \\
\hline & \multirow{2}{*}{ Intercept } & $0.497^{+3+1+}$ & $0.519^{+t+x}$ & 0.072 & $0.464^{+*+*}$ & 0.006 & $0.070^{* t+t}$ & $0.136^{t+x+}$ & 0.225 & $0.213^{t+4}$ & $0.158^{*}$ & 0.194 & 0.007 & $0.062^{*}$ & -0.042 & $0.214^{*+*+}$ & $0.625^{+* * *}$ \\
\hline & & $(0.049)$ & $(0.065)$ & $(0.050)$ & $(0.104)$ & $(0.019)$ & $(0.015)$ & $(0.017)$ & $(0.184)$ & $(0.037)$ & $(0.083)$ & $(0.125)$ & $(0.024)$ & $(0.038)$ & $(0.055)$ & $(0.076)$ & $(0.075)$ \\
\hline & \multirow{2}{*}{$A R$} & 0.052 & 0.150 & $1.380^{+20 x}$ & $0.854^{*+x+x}$ & 0.373 & $0.843^{+4 x+x}$ & $0.339^{*+* x}$ & -0.045 & $0.723^{\text {tat }}$ & $1.157^{* *+*}$ & 0.371 & $0.499^{* * * *}$ & $0.681^{* t * x}$ & $0.489^{* *}$ & $0.876^{+* x}$ & $0.498^{*+* x}$ \\
\hline & & $(0.041)$ & $(0.120)$ & $(0.314)$ & $(0.237)$ & $(0.356)$ & $(0.166)$ & $(0.100)$ & $(0.144)$ & $(0.191)$ & $(0.351)$ & $(0.361)$ & $(0.187)$ & $(0.215)$ & $(0.239)$ & $(0.308)$ & $(0.133)$ \\
\hline \multirow{18}{*}{0.5} & \multirow{2}{*}{ House Price-to-Income } & $-0.211^{* \star * *}$ & $-0.177^{* * *}$ & -0.017 & $-0.083^{*+*}$ & $-0.025^{*+}$ & $-0.084^{*+* t}$ & $-0.047^{* *}$ & $-0.058^{t+*+}$ & 0.011 & 0.025 & $-0.056^{* *}$ & 0.014 & $-0.104^{* \star *}$ & -0.008 & $-0.119^{t+2+t}$ & $-0.181^{*+x+x}$ \\
\hline & & $(0.079)$ & $(0.066)$ & $(0.025)$ & $(0.070)$ & $(0.049)$ & $(0.022)$ & $(0.049)$ & $(0.172)$ & $(0.084)$ & $(0.054)$ & $(0.062)$ & $(0.044)$ & $(0.039)$ & $(0.023)$ & $(0.101)$ & $(0.158)$ \\
\hline & \multirow{2}{*}{ Residential Investment } & 3.544 & 3.272 & -1.859 & $9.067^{+t+4}$ & $3.719^{*}$ & $11.172^{*+*+*}$ & -1.535 & 0.541 & $-9.373^{t+* x}$ & $-11.744^{*+*}$ & $4.616^{* *}$ & -2.854 & $11.205^{* * * *}$ & $5.685^{t+4}$ & 6.138 & $6.591^{t+*}$ \\
\hline & & $(4.887)$ & $(8.681)$ & $(7.129)$ & $(6.371)$ & $(9.158)$ & $(4.344)$ & $(5.382)$ & (13.878) & $(4.795)$ & $(2.718)$ & $(4.310)$ & $(5.971)$ & $(3.614)$ & $(2.933)$ & $(6.077)$ & $(5.032)$ \\
\hline & & $-0.063^{* * *}$ & $-0.042^{* * *}$ & $-0.047^{* * *}$ & $-0.024^{* * * *}$ & $-0.024^{* * *}$ & $-0.016^{* *}$ & $-0.016^{* *}$ & $-0.076^{*+*+}$ & -0.011 & -0.011 & $-0.013^{* *}$ & $-0.021^{1+*+*}$ & $-0.044^{* * *}$ & -0.008 & $-0.056^{* * * *}$ & $-0.049^{+*+x}$ \\
\hline & $\mathrm{FCl}$ & $(0.022)$ & $(0.031)$ & $(0.024)$ & $(0.023)$ & $(0.030)$ & $(0.024)$ & $(0.030)$ & $(0.051)$ & $(0.034)$ & $(0.030)$ & $(0.013)$ & $(0.017)$ & $(0.028)$ & $(0.020)$ & $(0.025)$ & $(0.015)$ \\
\hline & & $0.013^{*+* x}$ & $0.022^{*+* x}$ & 0.003 & 0.003 & 0.001 & 0.001 & $0.010^{*+* x}$ & 0.006 & $0.017^{*+x+}$ & $0.013^{* *}$ & 0.000 & $0.005^{*}$ & 0.004 & 0.001 & -0.002 & 0.000 \\
\hline & Household Debt & $(0.006)$ & $(0.003)$ & $(0.004)$ & $(0.003)$ & $(0.004)$ & $(0.002)$ & $(0.004)$ & $(0.007)$ & $(0.005)$ & $(0.004)$ & $(0.002)$ & $(0.003)$ & $(0.002)$ & $(0.002)$ & $(0.006)$ & $(0.003)$ \\
\hline & FDI & 0.277 & -0.307 & 0.135 & 0.068 & $0.345^{* *}$ & $0.649^{* t+}$ & -0.229 & $0.274^{* * t}$ & -0.175 & -0.200 & 0.062 & -0.074 & $0.588^{+* t+}$ & -0.163 & 0.084 & -0.033 \\
\hline & $\mathrm{FDI}$ & $(0.299)$ & $(0.437)$ & $(0.236)$ & $(0.349)$ & $(0.434)$ & $(0.178)$ & $(0.616)$ & $(0.509)$ & $(0.419)$ & $(0.352)$ & $(0.177)$ & $(0.207)$ & $(0.257)$ & $(0.221)$ & $(0.245)$ & $(0.411)$ \\
\hline & & -0.294 & -0.342 & -0.331 & 0.003 & 0.032 & $0.359^{+t+x}$ & 0.005 & -0.192 & -0.341 & -0.152 & -0.151 & $-0.249^{*}$ & -0.311 & -0.037 & $0.953^{\text {tat }}$ & -0.184 \\
\hline & Other Capital Flows & $(0.254)$ & $(0.369)$ & $(0.458)$ & $(0.291)$ & $(0.317)$ & $(0.232)$ & $(0.407)$ & $(0.585)$ & $(0.320)$ & $(0.280)$ & $(0.281)$ & $(0.247)$ & $(0.380)$ & $(0.303)$ & $(0.700)$ & $(0.242)$ \\
\hline & & $-0.030^{*}$ & -0.009 & -0.028 & -0.003 & -0.006 & -0.005 & 0.004 & $-0.071^{* * *+}$ & -0.004 & 0.027 & -0.013 & -0.014 & -0.020 & $-0.017^{*}$ & -0.009 & $-0.034^{* *}$ \\
\hline & Oil & $(0.030)$ & $(0.045)$ & $(0.027)$ & $(0.039)$ & $(0.042)$ & $(0.028)$ & $(0.035)$ & $(0.060)$ & $(0.059)$ & $(0.060)$ & $(0.030)$ & $(0.022)$ & $(0.047)$ & $(0.034)$ & $(0.041)$ & $(0.026)$ \\
\hline & Intercent & $0.154^{*+*+}$ & $0.129^{+ \text {th }}$ & 0.014 & $0.038^{* *}$ & -0.007 & 0.002 & $0.058^{*+*}$ & 0.028 & 0.047 & 0.046 & 0.024 & 0.001 & 0.018 & $-0.024^{*+*+*}$ & $0.056^{*}$ & $0.068^{t+x+x}$ \\
\hline & Intercept & $(0.042)$ & $(0.064)$ & $(0.044)$ & $(0.095)$ & $(0.025)$ & $(0.022)$ & $(0.022)$ & $(0.099)$ & $(0.035)$ & $(0.037)$ & $(0.059)$ & $(0.024)$ & $(0.031)$ & $(0.024)$ & $(0.079)$ & $(0.081)$ \\
\hline & $A R$ & $0.138^{* * * *}$ & $0.265^{* *}$ & $0.591^{t+x}$ & 0.114 & $0.412^{\text {t*t* }}$ & $0.242^{t+4}$ & $0.209^{* *}$ & $0.393^{\text {t+t }}$ & $0.376^{\text {tat }}$ & $0.588^{+* t+x}$ & $0.295^{t+2}$ & $0.431^{t+2}$ & $0.158^{*}$ & $0.337^{+* 4+}$ & $0.279^{*}$ & $-0.376^{t+2+x}$ \\
\hline & $A K$ & $(0.068)$ & $(0.099)$ & $(0.257)$ & $(0.232)$ & $(0.391)$ & $(0.175)$ & $(0.169)$ & $(0.297)$ & $(0.188)$ & $(0.148)$ & $(0.222)$ & $(0.168)$ & $(0.118)$ & $(0.269)$ & $(0.260)$ & $(0.084)$ \\
\hline & House Price-to-Income & $\begin{array}{l}-0.418^{\text {tot }} \\
(0.098)\end{array}$ & $\begin{array}{l}-0.522^{+4 *+} \\
(0.076)\end{array}$ & $\begin{array}{l}-0.014 \\
(0.029)\end{array}$ & $\begin{array}{l}-0.522^{+*+*} \\
(0.086)\end{array}$ & $\begin{array}{l}-0.109^{\text {tot }} \\
(0.027)\end{array}$ & $\begin{array}{l}-0.283^{+*+4} \\
(0.035)\end{array}$ & $\begin{array}{l}-0.108^{\text {t* }} \\
(0.047)\end{array}$ & $\begin{array}{l}-0.119 \\
(0.093)\end{array}$ & $\begin{array}{l}-0.147^{\text {tot+ }} \\
(0.051)\end{array}$ & $\begin{array}{l}-0.068 \\
(0.050)\end{array}$ & $\begin{array}{l}-0.454^{\text {tot+ }} \\
(0.040)\end{array}$ & $\begin{array}{l}0.013 \\
(0.059)\end{array}$ & $\begin{array}{l}-0.293^{\text {tot }} \\
(0.052)\end{array}$ & $\begin{array}{l}-0.103^{\text {tot+ }} \\
(0.023)\end{array}$ & $\begin{array}{l}-0.407^{*+2+x} \\
(0.089)\end{array}$ & $\begin{aligned}-1.459^{+*+1+} \\
(0.139)\end{aligned}$ \\
\hline & & & $12.545^{*}$ & $-35.862^{2+*}$ & -0.364 & -6.777 & $22.111^{* * *+}$ & $-13.724^{* *}$ & 0.531 & $-35.904^{* * *}$ & $-45.696^{*+* x}$ & -4.625 & -13.860 & $16.475^{* * *}$ & $25.470^{*+* *}$ & 1.601 & $53.075^{\text {tot+ }}$ \\
\hline & Residential Investment & $(8.267)$ & $(6.545)$ & $(9.125)$ & $(7.172)$ & $(6.977)$ & $(4.748)$ & $(6.265)$ & (9.052) & $(6.016)$ & $(3.155)$ & (3.690) & (12.370) & $(5.499)$ & $(3.290)$ & $(5.147)$ & $(4.200)$ \\
\hline & & $-0.132^{t+4 *}$ & $-0.067^{\star \star \star \star}$ & $-0.073^{* *+}$ & -0.007 & $-0.069^{* \star *}$ & $-0.072^{\star \star \star *}$ & $-0.067^{*}$ & $-0.118^{* * *}$ & 0.065 & $0.080^{*}$ & -0.007 & $-0.083^{* * *}$ & $-0.151^{* \star \star *}$ & $-0.041^{* \star * *}$ & $-0.119^{* \star * *}$ & -0.028 \\
\hline & $\mathrm{FCl}$ & $(0.034)$ & $(0.023)$ & $(0.029)$ & $(0.024)$ & $(0.014)$ & $(0.017)$ & $(0.039)$ & $(0.033)$ & $(0.046)$ & $(0.042)$ & $(0.013)$ & $(0.028)$ & $(0.023)$ & $(0.012)$ & $(0.021)$ & $(0.023)$ \\
\hline & & 0.004 & 0.006 & $-0.014^{* * * *}$ & -0.003 & $-0.004^{* \star *}$ & -0.006 & 0.003 & -0.004 & 0.001 & $-0.005^{* *}$ & $-0.009^{t+1+x}$ & 0.000 & $0.006^{* *}$ & $0.004^{\prime+4+x}$ & $-0.010^{* *}$ & -0.000 \\
\hline & Household Debt & $(0.004)$ & $(0.004)$ & $(0.003)$ & $(0.004)$ & $(0.001)$ & $(0.004)$ & $(0.003)$ & $(0.004)$ & $(0.003)$ & $(0.002)$ & $(0.002)$ & $(0.003)$ & $(0.002)$ & $(0.001)$ & $(0.005)$ & $(0.005)$ \\
\hline & & 0.349 & 0.044 & $0.657^{t+4}$ & $-0.550^{* *}$ & $0.959^{*+4}$ & $2.353^{* t+x}$ & 0.730 & $0.952^{t+4}$ & -0.879 & 0.421 & $-0.925^{* * *+}$ & 0.549 & $1.940^{+k+*}$ & $-0.467^{7+*+*}$ & 0.281 & $-1.488^{+n+x}$ \\
\hline 0.9 & FDI & $(0.494)$ & $(0.302)$ & $(0.252)$ & $(0.268)$ & $(0.249)$ & $(0.248)$ & $(0.472)$ & $(0.332)$ & $(0.560)$ & $(0.370)$ & $(0.134)$ & $(0.410)$ & $(0.263)$ & $(0.163)$ & $(0.276)$ & $(0.302)$ \\
\hline & & -0.589 & $-2.604^{* * *+}$ & $-2.823^{+* *+x}$ & $1.003^{+* t+}$ & -0.014 & $0.846^{* *}$ & 0.452 & $-1.289^{t+1+x}$ & $2.510^{* *+}$ & -0.078 & -0.026 & -0.422 & -0.283 & 0.043 & 0.012 & -0.313 \\
\hline & Other Capital Flows & $(0.708)$ & $(0.633)$ & $(0.743)$ & $(0.350)$ & $(0.267)$ & $(0.420)$ & $(0.867)$ & $(0.488)$ & $(1.257)$ & $(0.759)$ & $(0.168)$ & $(0.763)$ & $(0.520)$ & $(0.351)$ & $(0.872)$ & $(0.421)$ \\
\hline & Oil & -0.008 & -0.013 & -0.028 & -0.047 & $-0.050^{*}$ & -0.028 & 0.042 & $-0.180^{\star \star * *}$ & -0.037 & 0.017 & 0.003 & $-0.071^{*}$ & -0.047 & $-0.048^{* \star *}$ & $-0.117^{\star \star \star}$ & -0.058 \\
\hline & Oil & $(0.039)$ & $(0.023)$ & $(0.041)$ & $(0.032)$ & $(0.027)$ & $(0.026)$ & $(0.048)$ & $(0.046)$ & $(0.087)$ & $(0.072)$ & $(0.029)$ & $(0.040)$ & $(0.056)$ & $(0.014)$ & $(0.045)$ & $(0.042)$ \\
\hline & Intercept & $0.479^{*+*+}$ & $0.490^{+*+x}$ & $0.259^{+* t+}$ & $0.558^{*+*}$ & $0.139^{+t+x}$ & $0.106^{t+4}$ & $0.181^{* * *+}$ & $0.142^{\star}$ & $0.435^{* *+*}$ & $0.430^{*+*}$ & $0.547^{t+4}$ & $0.080^{*}$ & $0.143^{\text {t+x }}$ & -0.011 & $0.396^{+*+*}$ & $0.677^{* * * x}$ \\
\hline & Intercept & $(0.044)$ & $(0.055)$ & $(0.059)$ & $(0.109)$ & $(0.036)$ & $(0.025)$ & $(0.022)$ & $(0.085)$ & $(0.061)$ & $(0.053)$ & $(0.045)$ & $(0.043)$ & $(0.041)$ & $(0.024)$ & $(0.072)$ & $(0.079)$ \\
\hline & & -0.013 & -0.008 & $2.036^{+*+x}$ & $1.088^{+t+x}$ & $1.698^{t+x}$ & $0.871^{t+x}$ & $0.741^{*+*}$ & $0.855^{\text {tox }}$ & $0.857^{\star}$ & $1.601^{* *+*}$ & $0.338^{t+x}$ & $1.307^{* *}$ & $0.486^{\text {tat }}$ & 0.112 & $1.070^{\text {tate }}$ & $0.593^{+\ldots+x}$ \\
\hline & AR & $(0.092)$ & $(0.064)$ & $(0.384)$ & $(0.227)$ & $(0.209)$ & $(0.224)$ & $(0.163)$ & $(0.191)$ & $(0.439)$ & $(0.133)$ & $(0.120)$ & $(0.615)$ & $(0.158)$ & $(0.120)$ & $(0.240)$ & $(0.120)$ \\
\hline
\end{tabular}

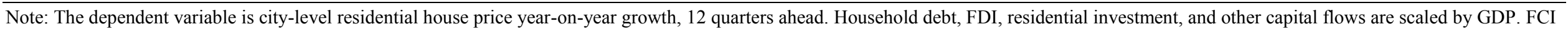

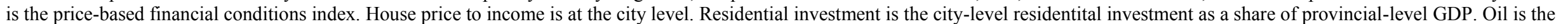

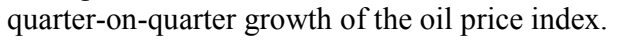


$\square \square$

Annex Table 5. United States: Pseudo-R ${ }^{2}$ Across Cities, One-year Ahead

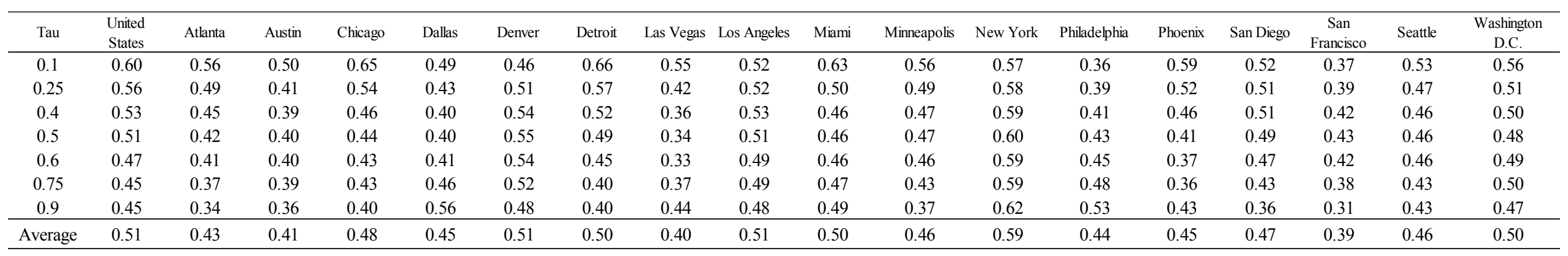

Annex Table 6. Canada: Pseudo- ${ }^{2}$ Across Cities, One-year Ahead

\begin{tabular}{|c|c|c|c|c|c|c|c|c|c|c|c|c|c|c|c|c|}
\hline$\square \square$ & पणए & 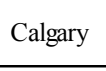 & पपएण & பயாण & पणाए & 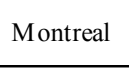 & $\begin{array}{c}\square \square\|\|\|\| \\
\square \square \square\end{array}$ & पषण & पमणाण & $\square \square \| ा \mathbb{~}$ & प्राणा & 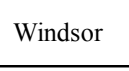 & पषणमाप & पण口冋口 & ए11⿴囗十 & 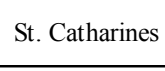 \\
\hline$\square \square$ & $\square \mathrm{IID}$ & $\square \mathrm{IID}$ & $\square \square$ & $\square \square$ & 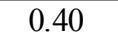 & $\square \square$ & $\square \square$ & 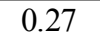 & $\square$ पाण & 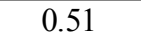 & $\square \mathrm{IID}$ & $\square \mathrm{IID}$ & $\square \square$ & $\square \square$ & $\square$ पाण & $\square \square$ \\
\hline पाण & $\square \mathrm{Cl}$ & पाए & $\square \square$ & $\square \mathrm{Cl}$ & पाण & पाण & 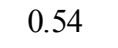 & 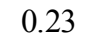 & 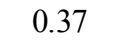 & 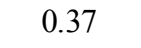 & पाए & पाए & $\square ण$ & $\square \square$ & 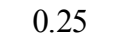 & $\square \mathrm{Cl}$ \\
\hline$\square$ & पण口 & $\square \square$ & $\square \square$ & $\mathrm{\square m}$ & पणा & पाण & $\square \square$ & $\mathrm{\square m}$ & $\square \square$ & $\square$ & $\square \square$ & $\square \square$ & $\mathrm{\square D}$ & $\square$ & $\square \square$ & $\square$ \\
\hline$\square$ & $\square \square$ & $\square$ & $\square \square$ & $\square$ & $\square \square$ & $\square \square$ & $\square \square$ & $\square$ & $\square \square$ & $\square$ & $\square$ & $\square \square$ & $\square$ & $\square \square$ & $\square \square$ & $\square \mathrm{Cl}$ \\
\hline$\square$ & $\square \square$ & $\square \mathrm{Cl}$ & $\mathrm{\square m}$ & $\square$ & $\square \mathrm{DL}$ & $\square \mathrm{ll}$ & $\square \square$ & $\mathrm{all}$ & $\square$ & $\square \mathrm{ll}$ & $\square \mathrm{ll}$ & $\mathrm{\square m}$ & $\square \square$ & $\square \mathrm{ll}$ & $\square \square$ & $\square \mathrm{ll}$ \\
\hline $\mathrm{\square पl}$ & $\square \mathrm{पण}$ & $\mathrm{\square m}$ & $\mathrm{\square m}$ & $\mathrm{\square m}$ & $\square$ & पाण & $\mathrm{\square m}$ & $\mathrm{all}$ & $\mathrm{\square m}$ & $\square$ & $\mathrm{\square m}$ & $\mathrm{\square m}$ & 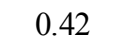 & $\square \mathrm{ll}$ & $\square \square$ & $\square \mathrm{ll}$ \\
\hline$\square$ & $\square \mathrm{DL}$ & $\square$ & $\square \mathrm{DL}$ & $\square \mathrm{DL}$ & $\square \mathrm{DL}$ & $\square \mathrm{DL}$ & $\square \mathrm{DL}$ & $\square \mathrm{DL}$ & $\square \mathrm{DL}$ & $\mathrm{\square m}$ & $\square \square$ & $\mathrm{\square m}$ & $\square \square$ & $\square$ & 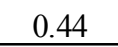 & $\square$ \\
\hline \begin{tabular}{l|l|l|l|}
$\square \square$ & \\
\end{tabular} & 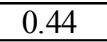 & 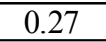 & 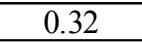 & 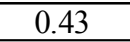 & 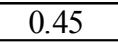 & 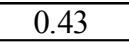 & 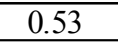 & $\begin{array}{lll}\mathrm{MU} \\
\end{array}$ & 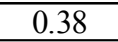 & 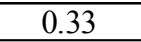 & 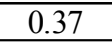 & 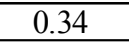 & 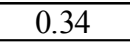 & 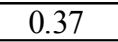 & 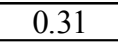 & 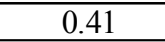 \\
\hline
\end{tabular}

Annex Table 7. Survey Descriptions

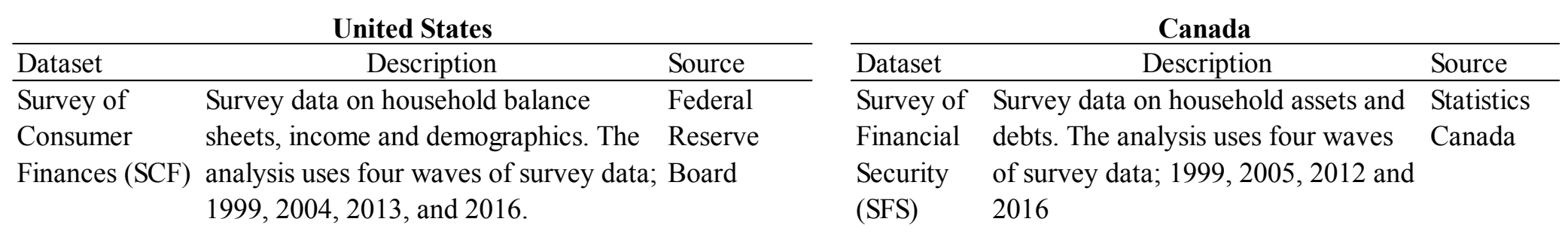




\section{REFERENCES}

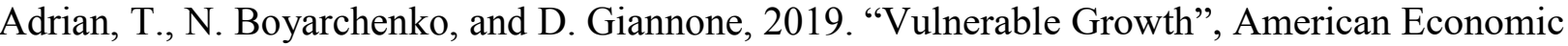

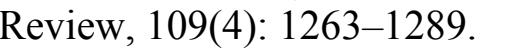

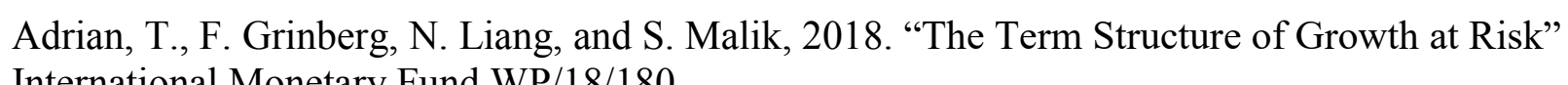

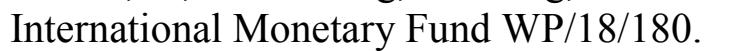

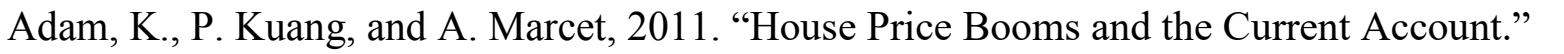

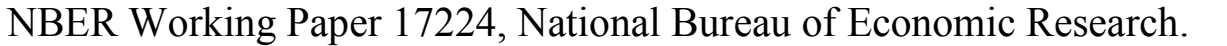

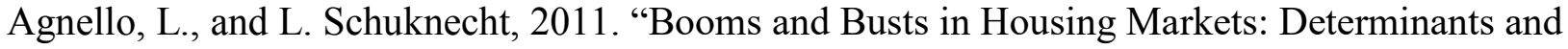
Implications" Journal of Housing Economics, 20(3), $171 \square \square \square \square$

Aizenman, J., and Y. Jinjarak, 2009 "Current Account Patterns and National Real Estate Markets” Journal of Urban Economics, 66(2), $75 \square \square \square$

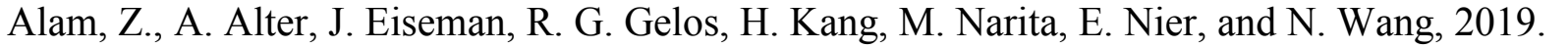

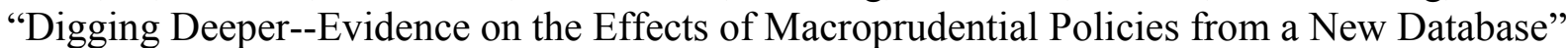

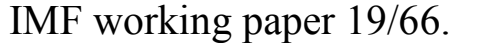

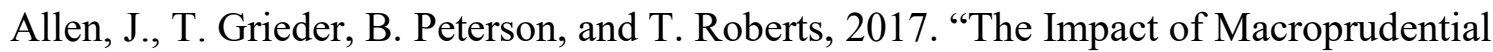

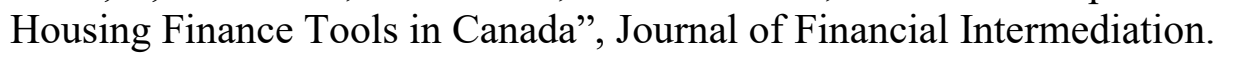

$\square \square$ Mqbali, L., O. Bilyk, S. Caputo, and J. Younker, 2019. "Reassessing the Growth of HELOCs in Canada Using New Regulatory Data," Bank of Canada, Staff Analytical Note 2019 $\square \square$ $\square$

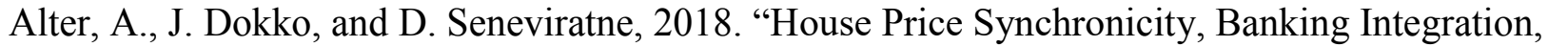
and Global Financial Conditions", International Monetary Fund, WP/18/250.

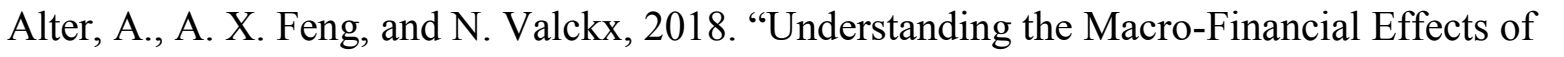
Household Debt: A Global Perspective."

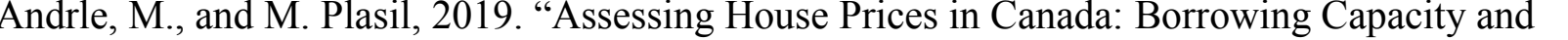

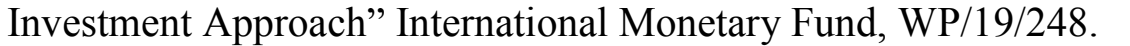 \\ $\square$

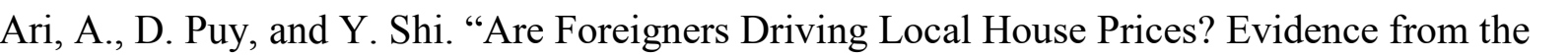
US" IMF Working Paper, forthcoming.

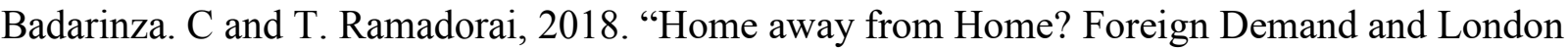

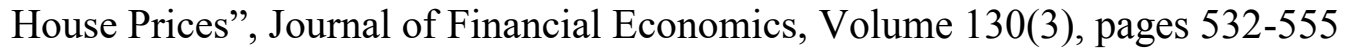

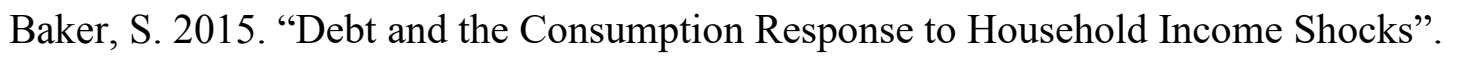

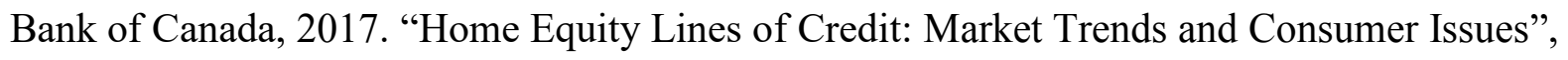

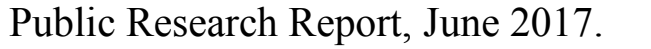




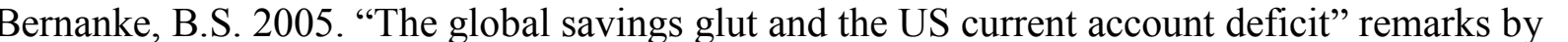

Governor Ben S. Bernanke at the Homer Jones Lecture, St. Louis, Missouri', The Federal

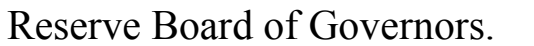

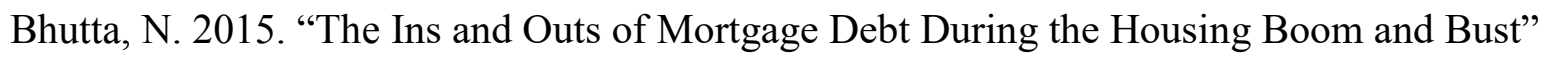

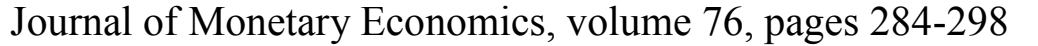

Bilyk, O. and M. teNyenhuis, 2018. "The Impact of Recent Policy Changes on the Canadian $\square$ ortgage Market", Bank of Canada -

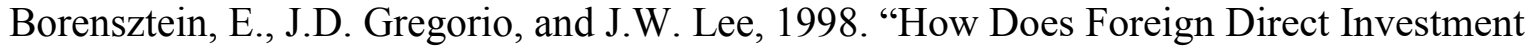
Affect Economic Growth?” Journal of International Economics, 45(1), $115 \square \square \square$

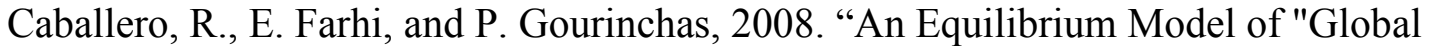

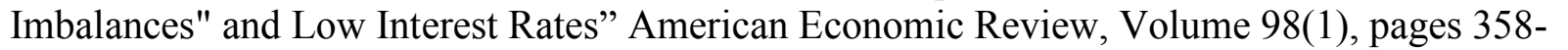
$\square \square \square$

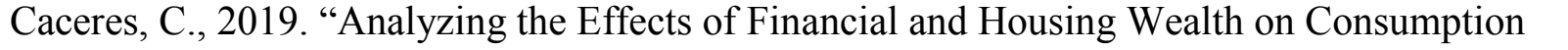

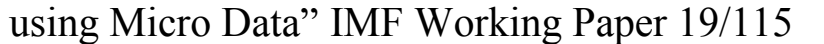

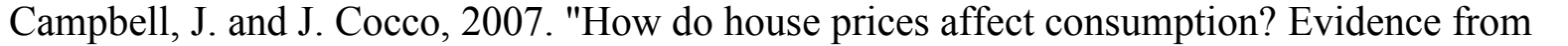

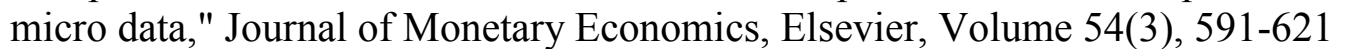

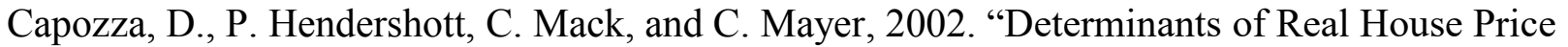
Dynamics.” NBER Working Paper 9262, National Bureau of Economic Research $\square$

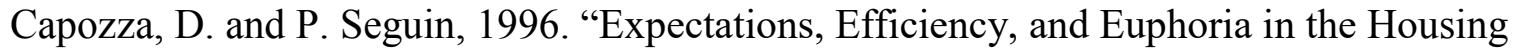

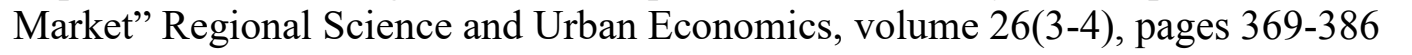

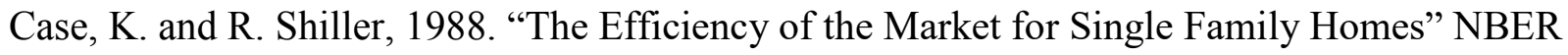

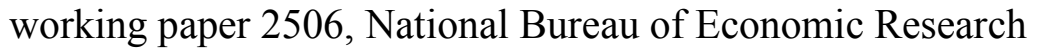

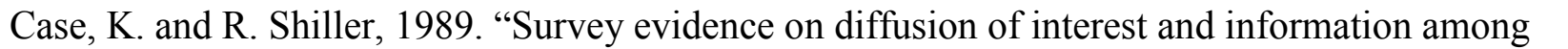

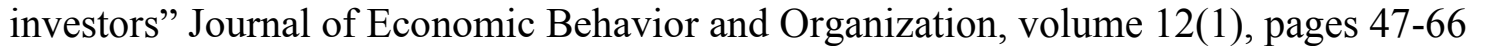

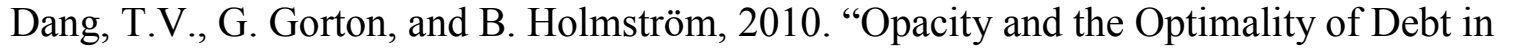

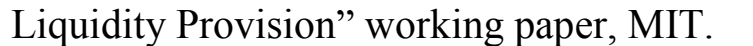

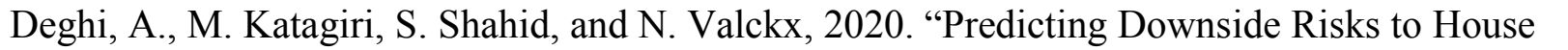

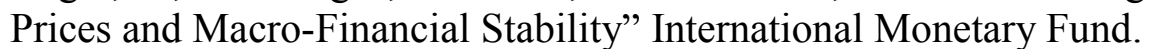

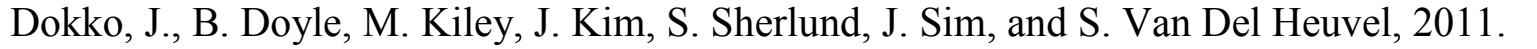

"Monetary Policy and the Global Housing Bubble" Economic Policy 26(66): $237 \square \square \square$

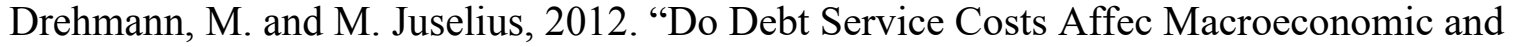
Financial Stability?” BIS Quarterly Review $\square$ 


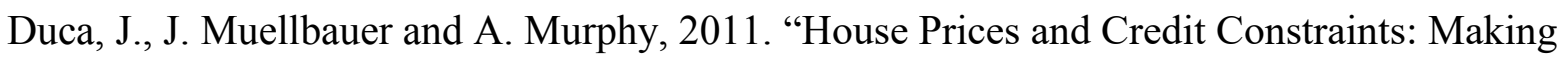

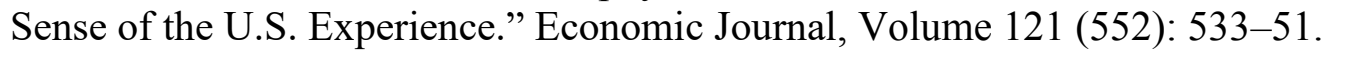

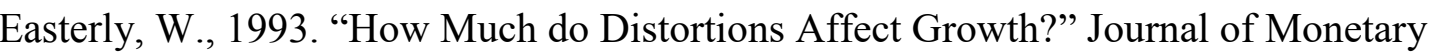

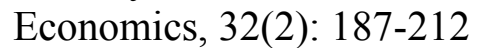

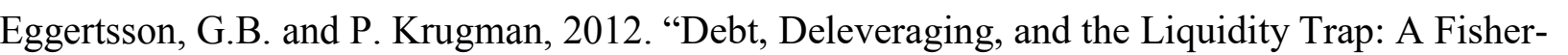
$\square \square \square \square \mid$ Koo Approach.” Quarterly Journal of Economics 127 (3): 1469- $\square \square \square$

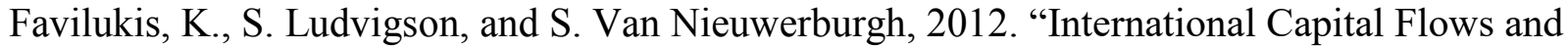

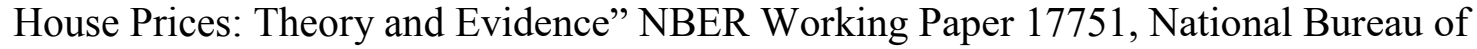

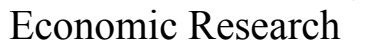

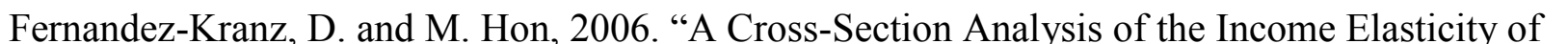
Housing Demand in Spain: Is There a Real Estate Bubble?” The Journal of Real Estate Finance

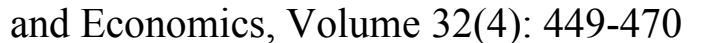

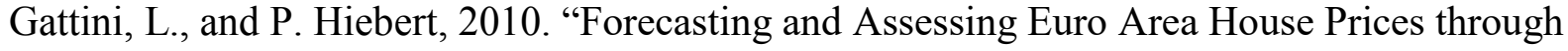
the Lens of Key Fundamentals.” Working Paper 1249, European Central Bank, Frankfurt,

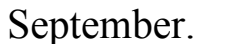

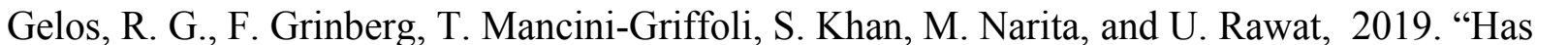

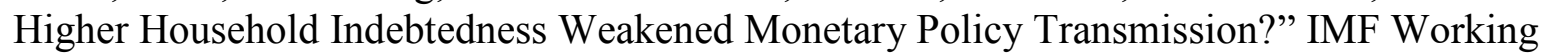

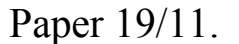

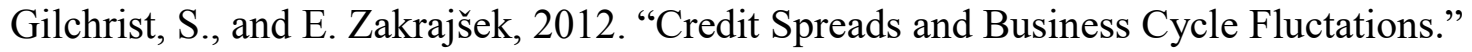

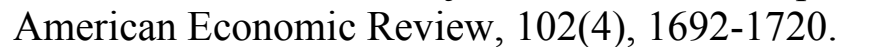

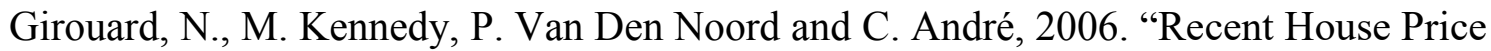
Developments: The Role of Fundamentals.” OECD Working Paper/475 $\square$

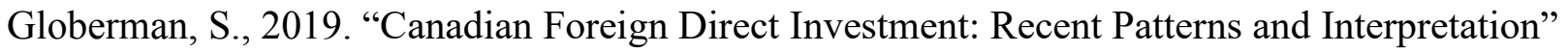

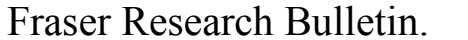

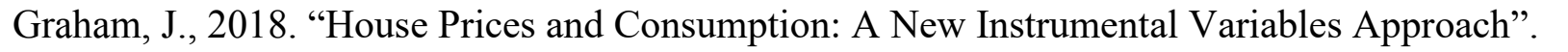

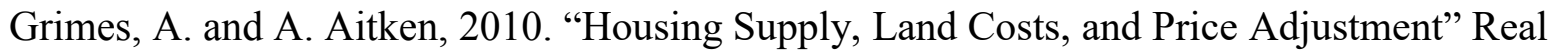

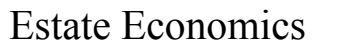

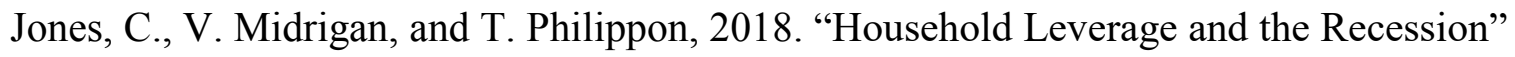

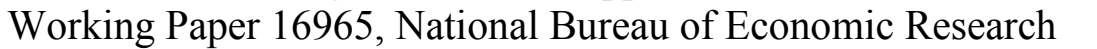

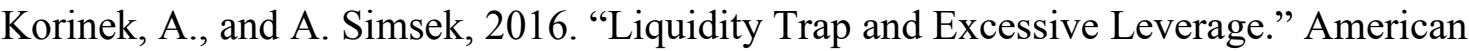

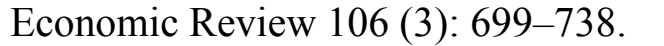

Krnzar, J., and J. Morsink, 2014. "With Great Power Comes Great Responsibility: Macroprudential Tools at Work in Canada.” IMF working paper 14/83. 


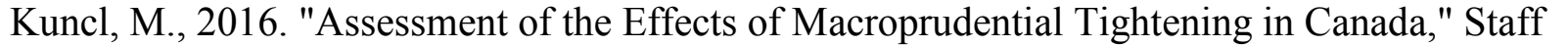

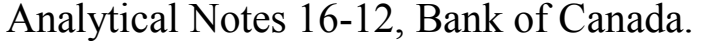

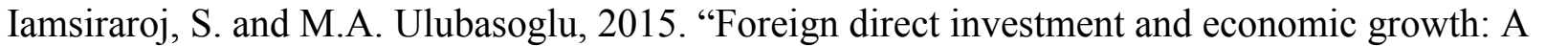

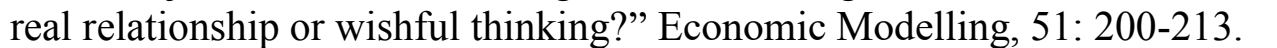

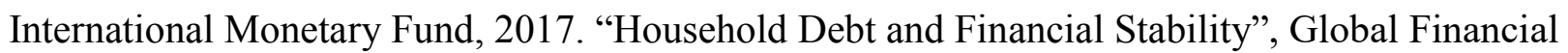

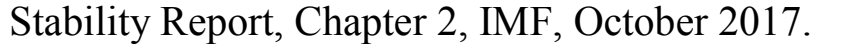

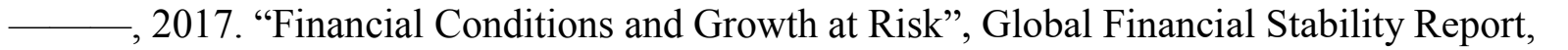

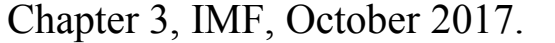

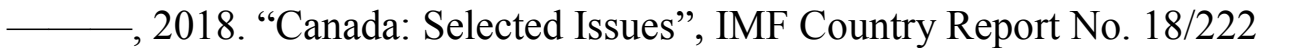

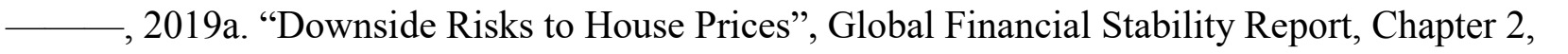

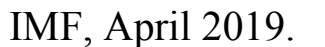

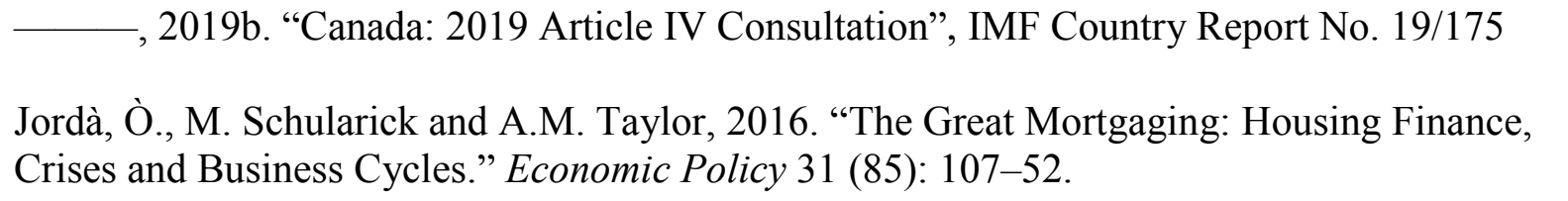

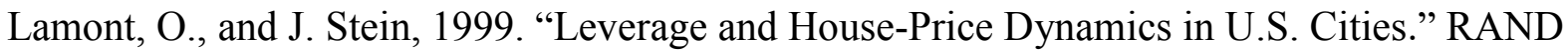

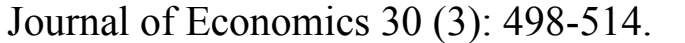

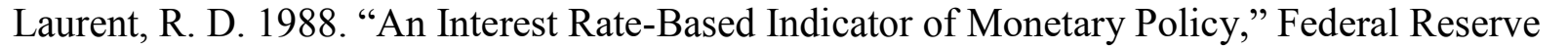

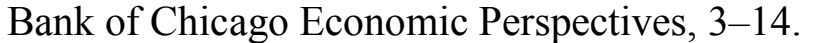

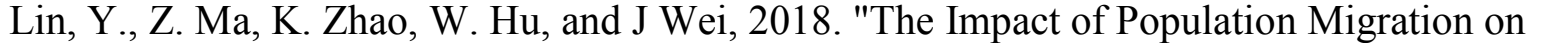

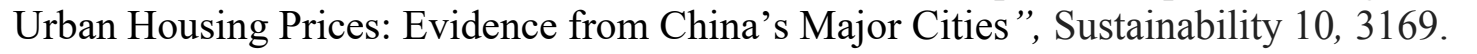

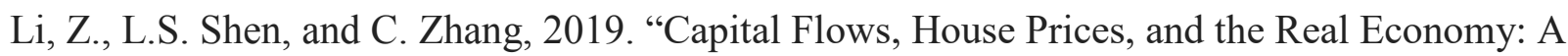
"China Shock" in the US Real Estate Market." $\square$

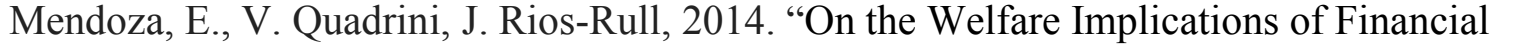

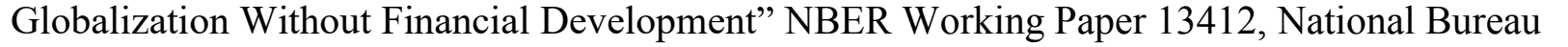

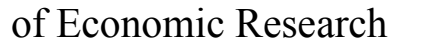

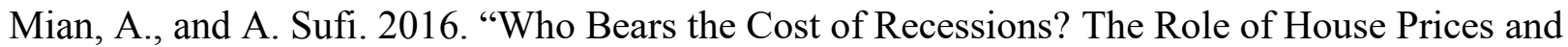
Household Debt." Chapter 5 in Handbook of Macroeconomics, edited by John B. Taylor and

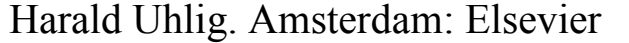

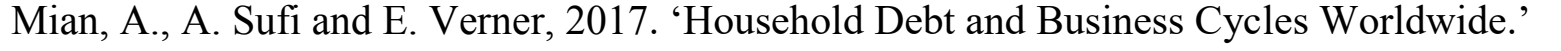

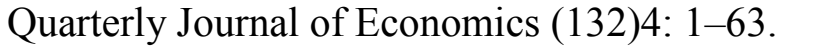

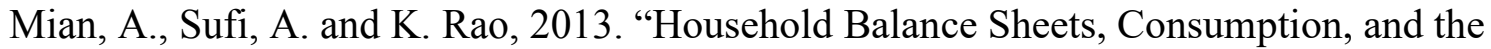

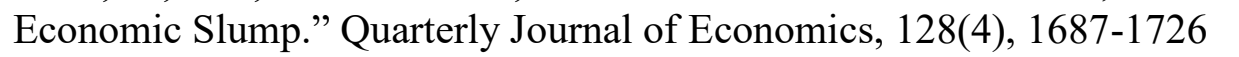




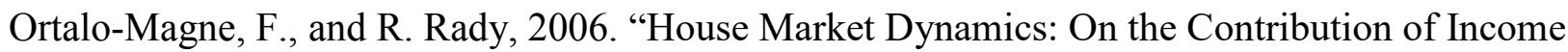
Shocks and Credit Constraints" The Review of Economics Studies, 73(2), 459 $\square \square \square$

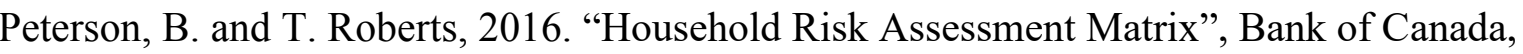

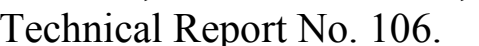

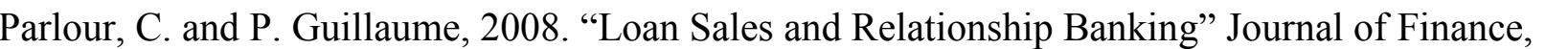

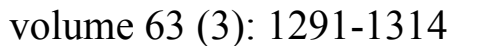

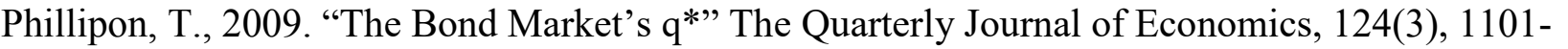
$\square|\square| l \mid$

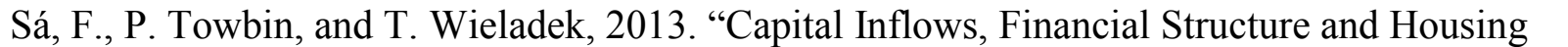
Booms"

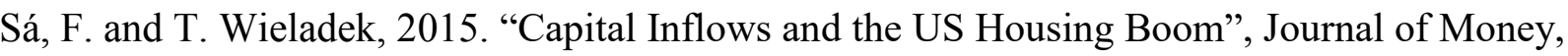

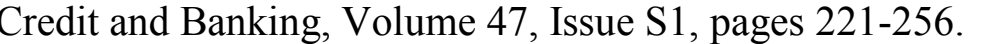

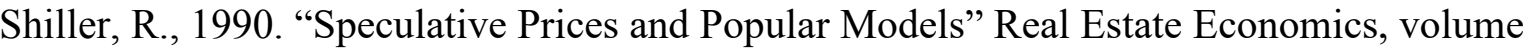

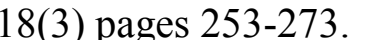

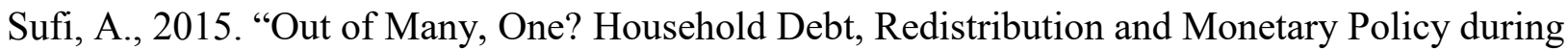

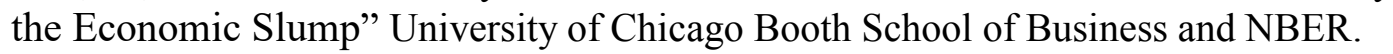

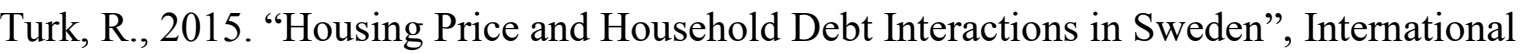

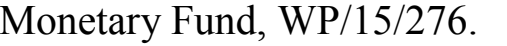

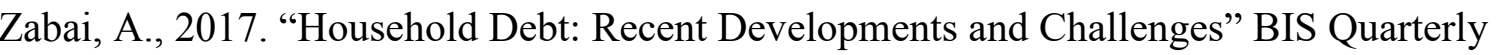
पणापण 